\title{
Gender and Verse
}

\section{Religion in New Zealand Women's Poetry, 1970-2019}

By

Vida Long

A thesis submitted to the Victoria University of Wellington in fulfilment of the requirements for the degree of Master of Arts in Religious Studies

School of Social and Cultural Studies

Victoria University of Wellington

2020 


\section{CONTENTS}

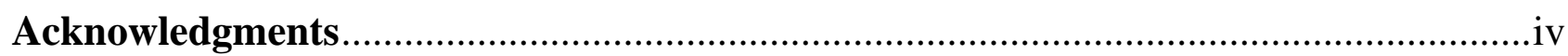

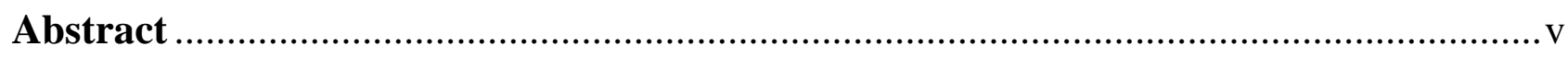

\section{Introduction}

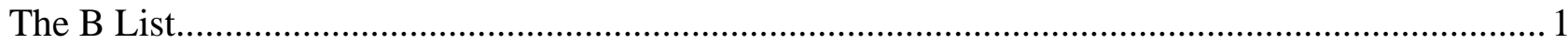



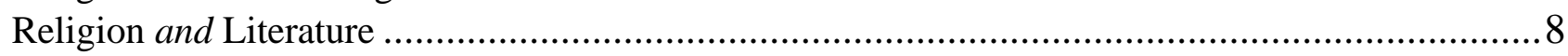

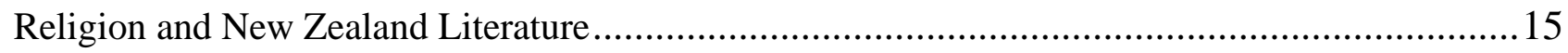

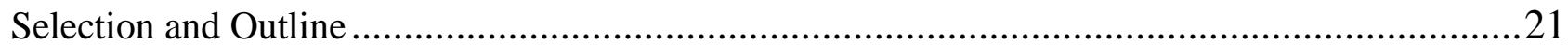

\section{Chapter One}

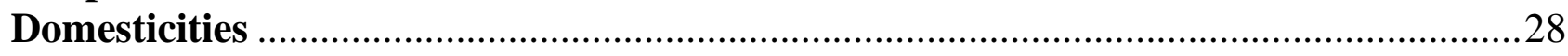

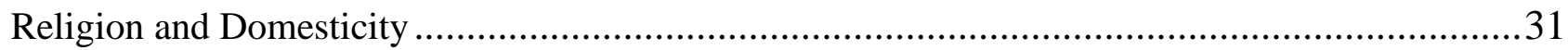

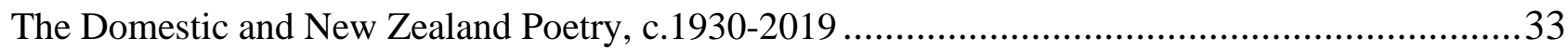

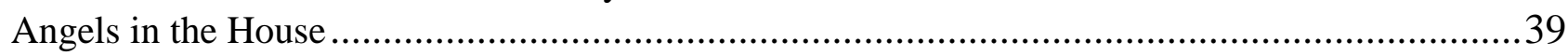

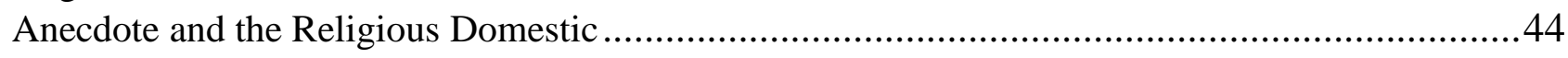

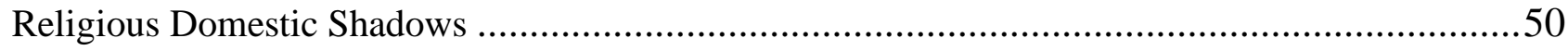

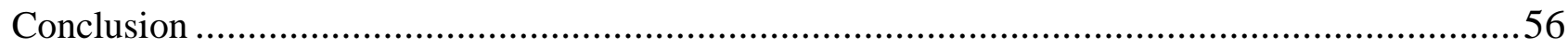

\section{Chapter Two}

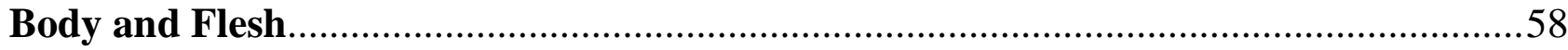

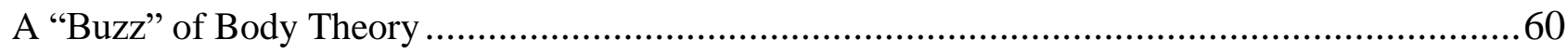

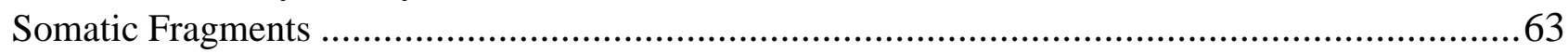

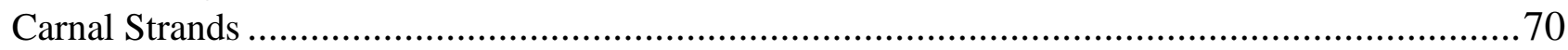

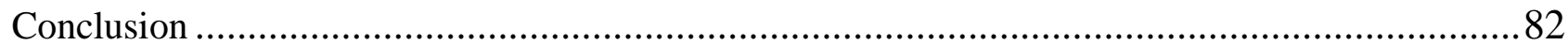

\section{Chapter Three}

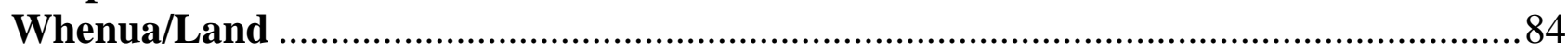

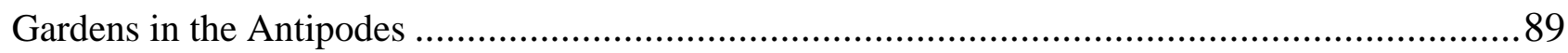

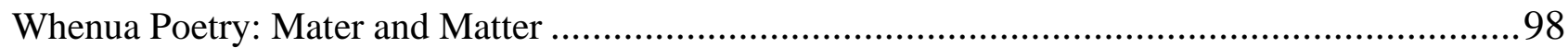

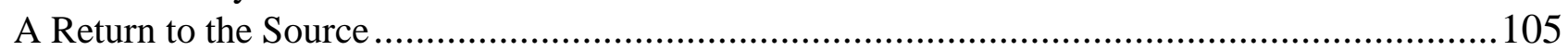

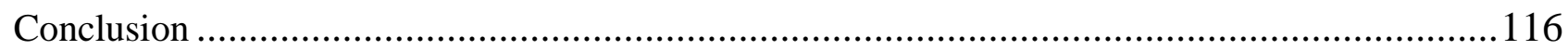

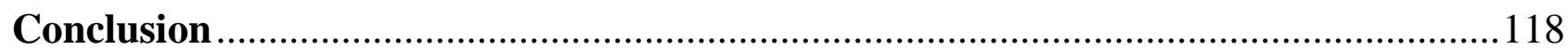

\section{Bibliography}

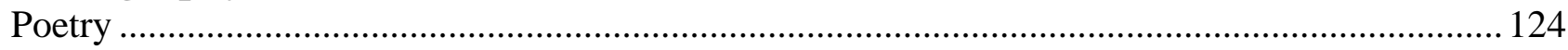

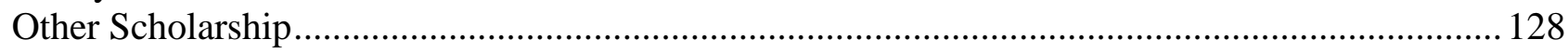




\section{ACKNOWLEDGMENTS}

I'm very grateful to my supervisors, Philip Fountain and Geoff Troughton, for their insight, suggestions, guidance, assurance and patience throughout this process.

Thanks also to Paul Morris, for his encouragement and poetry recommendations over the last few years.

Thank you to the VUW Religious Studies department, and Kelly Koon.

Thanks to my family, and to Miriam for letting me write annotations in all your poetry books. 


\begin{abstract}
This thesis explores the remarkable, surprising and enduring presence of religion within the writings of New Zealand women poets since the 1970s. Analysing a comprehensive range of poems, I argue that religion is a dynamic and compelling feature of women's poetry, emerging in a number of distinctive forms and tones. Using a thematic analysis, I explore religion in relation to domesticities, body and flesh, and whenua/land. I show that women poets deploy and rework religious ideas in ways that illuminate their gendered perspectives and experiences. Arguing that religion should be brought back into the centre of the scholarly analysis of New Zealand literature, I advance a fresh approach to the concept of religion. This framework acknowledges the interdependence and mutual imbrication of 'religion' and the 'secular', and also facilitates attention to 'spirituality'. This expansive framework affords careful investigation into the interrelationships between all three of these modern categories. Having shown that religion permeates New Zealand women's poetry and that attending to religion's presence is vital for interpretation, I argue for a bona fide crossdisciplinary conversation between religious studies and literary studies; a revitalised investigation on 'religion and literature' will be productive for both fields.
\end{abstract}




\section{INTRODUCTION}

\section{The B List}

In 1938, the National Historical Committee was tasked with carefully considering the subjects for inclusion in the New Zealand Centennial Publications. This standing committee, as it was known, deliberated over which subjects should be given preference, and which ought to be backgrounded to make room for those of truly national importance. According to Rachel Barrowman, this eminent group of scholars arrived at some clear decisions, though not without significant debate and some internal dissent: "Religion, science, women and war lingered on the ' $\mathrm{B}$ '

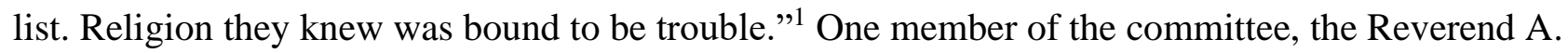
B. Chappell, advised on banishing the "sex-war" and the "New Zealand Wars" along with "the antipathies of religious denominations" to "the limbo where all anachronisms belong". 2 Eventually, however, women were included, but religion was not.

This thesis explores the remarkable, surprising and enduring presence of religion within the writings of New Zealand women poets. Despite lengthy histories of neglect and occlusion, predating even the decisions of the Centennial historians, I find that religion is neither anachronistic, nor merely bogged down by denominational antipathies. Instead, women poets have frequently and deftly deployed religious language, metaphors and allusions in their work. This is not only the case for New Zealand's supposedly more religious past, but also of contemporary poets. The side-lining which still characterises the treatment of religion in New Zealand literature - and, indeed, the still very real tendency to also assign women to the ' $\mathrm{B}$ list' - is not reflected in the poetry itself. Troubling perhaps, but hardly anachronistic, religion is surprisingly pertinent for the study of New

\footnotetext{
${ }^{1}$ Rachel Barrowman, "History and Romance: The Making of the Centennial Historical Surveys" in Creating a National Spirit: Celebrating New Zealand's Centennial, ed. William Renwick (Wellington: Victoria University Press, 2004), 167.

${ }^{2}$ Ibid.
} 
Zealand literature, and consequently also for the examination of the culture and history of New Zealand.

In this thesis I explore the articulation of religion in the poetry of New Zealand women since the 1970s. Analysing a wide range of poems, I argue that religion is a crucial and compelling feature, emerging in a number of distinctive forms, themes and tones. My focus on women poets allows an exploration of how religion and gender are articulated together. I suggest that there are significant shared contours and striking areas of gravitation and return in the articulation of religion in New Zealand women's poetry. Religion is a constant and also changing dimension. It plays a dynamic role in shaping the imaginations, thoughts and conversations which are part of this key domain of national literary culture.

Given religion's overwhelming and diverse presence in the poetry analysed in this thesis, it is necessary to ask why religion is such a neglected area of New Zealand literary scholarship. In significant part, this can be attributed to historical legacies of scholarly distaste and disinterest, including the literary nationalists of the 1930s and the men that comprised the committees who made decisions about the narration of New Zealand's emerging national story. Enduring historical and institutional pressures have resulted in New Zealand being touted as 'secular', and religion has consequently been regarded as an awkward and uncomfortable presence, more easily ignored or dismissed than taken seriously as an element deserving critical enquiry. Scholarly frameworks have not focused on capturing and interrogating the place of religion in New Zealand literature. Where analysis has occurred, it has almost always been done lightly. This thesis seeks to bring religion back into the centre of scholarly analysis of New Zealand literature. It does so by drawing from both religious studies and literary studies scholarship, giving weight to the conjunction in 'religion and literature' and recognising the mutual benefits for a bona fide cross-disciplinary conversation between the two fields. 
A fresh approach to the concept of religion proves an incisive tool with which to examine its presence within poetry. Adopting a framework that acknowledges the interdependence and mutual imbrication of 'religion' and the 'secular', I disagree with a reified and sharp bifurcation. Religion and the secular are not opposites, but rather inhere within each other. Moreover, these are not the only relevant categories. I include attention also to the amorphous notion of 'spirituality'. This inclusion is designed to disrupt a binary religious-secular framework, by asserting a more complicated plane of relationships. Spirituality is a disruptive category, because its semantic resonances locate it within as well as alongside religion and the secular. My study of religion, therefore, is not limited to formal traditions, orthodox theologies, churchiness or confessional discourse. Instead, I pursue a much broader array of subjects. This more expansive and dynamic framework affords careful investigation into the interrelationships and hybridity between all three modern categories. This trialectical framework allows for a rich and nuanced analysis of religion within the poetry, one which frees secularity from its binds as a mere foil to religion or as just an empty and contentless signifier. Religion, understood in this way, permeates New Zealand women's poetry, and subsequently is an active and vital element in New Zealand literature. It does not deserve to sit on the 'B list' any longer.

\section{Religion in A Secular Age}

This thesis uses a trialectical framework to explore the interrelationships between the religious, spiritual and secular. ${ }^{3}$ This goes against a tendency to study religion and the secular as oppositional. An emphasis on a secular-religious binary appears to have grown out of what Charles Taylor calls "subtraction stories", in which it is thought that modernisation will inevitably cause

\footnotetext{
${ }^{3}$ In this thesis I use the words 'trialectic' and 'trialectical' to describe an interpolating and interconnected cohesion and mutual creation of concepts. 'Trialectic' conceptualises a ternary approach which accepts relationality, friction and productivity between religion, the secular and the spiritual. I use it with the awareness of its usage in physics, geography and philosophy, but not with reliance on its definition in any of these fields.
} 
religion's marginalisation and decline. ${ }^{4}$ Subtraction stories are narratives of modernity which explain how human beings lose, reject or liberate themselves from "earlier, confining horizons, or illusions, or limitations of knowledge". Taylor's view is that the subtraction story is inadequate as it leaves little room for the complications that people exhibit in practice. He argues that the religious-secular binary, despite its prevalence in popular thought, is incorrect and limits the study of religion. In this thesis, in order to analyse religion in New Zealand women's poetry with acuity, it is essential to establish an understanding of religion and the secular which goes beyond binary simplifications. An expansive understanding of 'religion' enables us to read the vibrancy of religion in New Zealand women's poetry.

An emphasis on New Zealand's secularity, and secularity in New Zealand literature, has resulted in the neglect of religious themes and dynamics in literary studies. Moreover, assumptions about the primacy of secularity have yielded some weak reflections on categories of religion and secularity alike. These demonstrate a failure to appreciate the extent to which religion and the secular interact and inhere within each other. In this thesis I aim to go beyond the prominent subtraction story and the oppositional religious-secular binary, in order to show the dynamic, provoking and revealing readings which can be afforded if a more expansive and relational understanding of religion is brought to New Zealand women's poetry. Therefore, in this thesis, religion, the secular and the spiritual are conceived as interdependent and relational components, within a trialectical framework.

A trialectical framework builds on scholarly reconfigurations of religion which understand the religious and the secular in dynamic relationship with each other. ${ }^{6}$ It both undermines binary

\footnotetext{
${ }^{4}$ Charles Taylor, A Secular Age (Cambridge.: Belknap Press of Harvard University Press, 2007), 22.

5 Ibid.

${ }^{6}$ Peter van der Veer's work on secularity and religion also emphasises the importance of problematising the secular and religious categories. He explains how the master narrative of secularisation can subsume all divergences and argues for
} 
oppositions and creates space for a dynamic series of relationships within the study of religion. Charles Taylor lays the ground for this approach in A Secular Age. For Taylor, the secular age is defined by contestation and notably the ability to self-consciously believe or not believe. ${ }^{7}$ The contestation of Taylor's secular age incorporates variegated positions and vocabularies other than 'religion' and 'secular'. ${ }^{8}$ The addition of the spiritual to the trialectical framework addresses this space of contestation and variegation.

The introduction of spirituality, a less reified and historicised term, allows us to theoretically open up the space between religion and the secular in order to view religion in poetry more expansively. It disrupts a secular narration and recognises the way that religion and the secular are shifting fields. A religious-secular-spiritual framework allows these three elements to be understood as an interpolating trialectic. Additionally, the use of spiritual language became more prevalent in the 1960s and 1970s. This coincides with the period of focus for this thesis, 1970-2019, and therefore the inclusion of the spiritual is particularly relevant.

The 'spiritual' is an indeterminate category that merges into both secularity and religion. My approach builds upon the work of Courtney Bender and Ann Taves in What Matters? Ethnographies of Value in a Not So Secular Age, which demonstrates the unfixed nature of the spiritual as a category, and the ways both religion and the secular can invoke it. Their work explains how the notion of spirituality breaks down the limitations of the religious-secular binary and emphasises how the three terms work together dynamically. ${ }^{9}$ For Bender and Taves, any understanding of a religious-secular binary, even one which acknowledges the religious and the understanding religion and the secular as mutually interdependent. See Peter van der Veer, Imperial Encounters: Religion and Modernity in India and Britain (Princeton: Princeton University Press, 2001), 14-28.

${ }^{7}$ Taylor, A Secular Age, 544-545.

${ }^{8}$ Ibid., 548-549.

${ }^{9}$ Courtney Bender and Ann Taves, "Introduction: Things of Value" in What Matters? Ethnographies of Value in a Not So Secular Age, eds., Courtney Bender and Ann Taves (New York: Columbia University Press, 2012), 19. 
secular as co-consituted formations, has its limits. ${ }^{10}$ These limits come to the fore when we consider how often the term 'spiritual' interacts with both 'religion' and 'secularity'. ${ }^{11}$ While, at first glance, the spiritual would appear to unproblematically align with religion, often it is used to designate something that is not overtly religious; at other times, it is more definitely incompatible with religion but compatible with the secular. ${ }^{12}$ Bender and Taves' disruption of binary categories allows relationalities to come to the fore. Their approach recognises that religion and the secular are dynamically related and understands how spirituality bleeds into both and creates better space for the critical consideration of the problem of religion within New Zealand women's poetry.

Recognising spirituality's ties to both religion and the secular allows us to identify transcendence in poetry beyond formally recognised religious discourse and institutions. Poetry functions within fluid structures and flexible parameters. Because this thesis is not examining religious poetry, but rather religion in poetry, and the ways religion has been used in metaphors, allusions, hints, suggestions and imaginations, a trialectical framing lends itself to my analysis.

Christianity is not the only tradition dealt with in this thesis. It is, however, the predominant one. This prevalence exemplifies the extent to which Christianity has seeped into the work of New Zealand women poets, and is interpreted in multi-layered and diverse ways. Sometimes this includes the interpretation or use of biblical text; elsewhere it is done through references to traditions of Christian ritual and liturgy. In women's poetry, the institutions and hierarchies of the Christian church are examined, unpicked and sometimes refashioned in ways which reveal an acutely gendered response to Christianity. The materiality and spectres afforded by Christian

\footnotetext{
${ }^{10}$ Ibid., 3.

11 Ibid.

12 Ibid., 6.; The 'spiritual but not religious' category also has relevance for this discussion, as does Sam Harris' (a prominent critic of religion) argument that spirituality separated from the irrationality of religion is important for humanity and is compatible with the secular. See Sam Harris, End of Faith: Religion, Terror, and the Future of Reason (New York: W.W. Norton \& Co. 2004).
} 
imagery and references are used in a variety of modes and lights. Christianity in some poems is used to explore legacies of colonisation and voices of protest.

While some poets are clearly writing from within Christianity, many are not; regardless, Christianity remains a tradition which many poets address, sometimes with commendation and nostalgia, and sometimes with critique and subversion. The trialectical focus is particularly effective for those poems which subvert and critique Christianity. Some poems enter into complex encounters between Māori and Christian allusions, or afford a wider reading beyond formal Christianity. Thus, opening the frame of analysis beyond religion narrowly defined allows for the appropriate exploration of poems in which Christianity, and religion generally, is complex and provoking.

A framework which encourages relationality enables me to focus on how these different ideas, notions and terminologies are related in sometimes unexpected and indistinct ways. In order to articulate this fluid relationality, I use the vocabulary of the sociologist Thomas Luckmann. His theory of transcendence envisions how religious or spiritual transcendence exists between the everyday, profane domain and the transcendent, sacred domain. ${ }^{13}$ Transcendence ranges from "little" transcendences, through "intermediate" transcendences, to "great" transcendences. ${ }^{14}$ These do not happen regimentally within these three categories but exist in a fluid state between the profane and sacred. They allow for religion to be conceptualised beyond a sharply reified and easily demarcated domain. In this thesis I return to Luckmann's "little" transcendences. These encapsulate the fluid transcendences that occur between the profane and the sacred, and represent the blurred interconnections between the religious, the secular and the spiritual.

\footnotetext{
13 Thomas Luckmann, “Shrinking Transcendence, Expanding Religion?” Sociological Analysis 51, no. 2 (1990): 127 129; The Invisible Religion: The Problem of Religion in Modern Society (New York: The Macmillan Company, 1967), 58.

${ }^{14}$ Luckmann, “Shrinking Transcendence," 129.
} 
Secularity continues to inhere within religiosity, and religion bleeds into secularity. The New Zealand secular is still deeply influenced by religion. Religious ideas have not disappeared; they are still present, and poets wrestle with them because they remain part of the cultural domain. Attending to these discursive presences is illuminating, interesting and important. My thesis does not attempt to nail down essential meanings of religion or the spiritual, as doing so would be counterproductive. Instead, I work around the edges and contours of religion in New Zealand using an expansive trialectical framework which draws out the complexities and nuances of religion in New Zealand women's poetry.

\section{Religion and Literature}

Studies of religion and literature observe and analyse dynamic interchanges between societies, their religiosities and their literary productions. There is a reciprocity and productivity between religion and literature which is illuminating for scholars working in both fields. There are a multitude of approaches to this area of study and yet a hurdle faced in the initial stages of beginning this research was observing that my own did not conform to existing study models of religion and literature, within either religious studies or literary studies. This is in part due to a conceptual split between studies of literature in religious studies, and literary studies of religion. Both forms of study have produced work that contributes to my own, however, I resist the necessity of this split. This thesis adopts a 'religion and literature' approach, in which I give weight to the conjunction, and interrogate and operate within the intersections of the fields of study. A bona fide study of religion and literature will grant weight to both disciplines, drawing upon the extensive scholarly contributions from each field. Rather than this being a study of religion in literature or the literariness of religion, I see a study of 'religion and literature' as one in which both disciplines can be treated with fluency. 
Other studies of religion and literature have adopted different approaches. Occasionally the conversation appears to be dominated by arguments on the ways religion and literature should be studied, reflecting disciplinary anxieties and debates. ${ }^{15}$ These arguments show some sharp divisions in the academic literatures over what texts deserve study under the banner of religion and literature, and how these studies should be conducted. I find that most studies of religion and literature focus on three discrete areas: theology and literature, the study of religious literary writers, and the analysis of religious allusion in literary texts.

Theology and literature is perhaps the most established branch. This involves the reading of theological texts with attention to their literary affordances, or studying 'the literariness of religious texts', such as reading the Bible or the Quran as poetry. Some linguistic determinacy links theology and literary studies, as theology is a cognate of $\theta \varepsilon o ́ \varsigma /$ theos $+\lambda$ oүía / logia which literally translates to "words about God". ${ }^{16}$ This thesis is not a theology and literature study, which is not to say that theology is irrelevant to the project. Although I am not engaged in a confessional project on the study of religion, being attuned to theological resonances plays an integral part in the reading and analysis of the poetry examples used in this thesis, which sometimes specifically reference or quote religious scripture. Therefore, theological texts influence some of the poets I sample from, and being able to identify and analyse those moments aids my analysis. Many poets utilise the

\footnotetext{
${ }^{15}$ For a broader discussion of debates on religion and literature, see Eric Ziolkowski, "Religion and Literature: History and Method," Brill Research Perspectives in Religion and the Arts, 3 (1) (2019): 1-112. The academic journal Religion and Literature also has a long-running commentary on the intricacies of the field. Additionally T. S. Eliot's "Religion and Literature" essay is often quoted in discussions on this area of study; see Cleo Mcnelly Kearns, "Religion, literature, and society in the work of T. S. Eliot" in The Cambridge Companion to T. S. Eliot ed. Anthony David Moody (Cambridge: Cambridge University Press 1994), 77-93.

${ }^{16}$ Kenneth Burke, The Rhetoric of Religion: Studies in Logology (Berkley: University of California Press, 1970), 1-42; The connection between The Word (of God) and words (lower case) can also be made. OED, s.v. "theology".
} 
compatibility of religious texts and poetry, which explains the prevalence of theological references which appear in much of the poetry I examine. ${ }^{17}$

The study of religious literary writers is another possible mode of religion and literature. This is the analysis of religion in literary works by writers who are identified as religious. Interestingly, the compatibility of poetry and religion is evident in the fact that a majority of these studies focus on religious poets. For example, John Milton, John Donne, Gerard Manley Hopkins, and Christina Rosetti are studied as religious poets. There is an emphasis on biography in such studies. In this thesis I draw upon biography at times, but I also move beyond being bound by biographical information. My intent is not to study 'religious poetry' and I am not concerned with whether the poets I sample from are 'religious' or not. However, when a religious affiliation or connection is evident, either in the text or through known biographical information, I occasionally note, or expand on, it. ${ }^{18}$

The analysis of religious allusion in literary texts which are not clearly religious builds on the study of religious literary writers. Such work has allowed the parameters of religion and literature to expand, and for religion to be analysed in a variety of different literary texts. These studies occasionally encounter criticism or resistance, particularly when the selected primary material is a contemporary text. ${ }^{19}$ Such studies greatly influence my own approach; however, these are predominantly undertaken in literary studies, and while mine is a study of literature I seek to

\footnotetext{
17 The former British Poet Laureate Carol Ann Duffy has described how "Poetry and prayer are very similar", see Hephzibah Anderson, "Christmas Carol," The Guardian https://www.theguardian.com/books/2005/dec/04/poetry.features (accessed August 21, 2019). In her poem "Writing Home: 15", New Zealand poet Dinah Hawken writes that "prayer is full of poetry", see It Has No Sound And Is Blue (Wellington: Victoria University Press, 1987), 37.

${ }^{18}$ Cultural backgrounds and Māori tribal affiliations are also noted in places.

19 John Dennison notes, in his study of the poet Seamus Heaney, an "unwillingness to consider the religiosity" of Heaney's work. See Dennison, Seamus Heaney and the Adequacy of Poetry (New York: Oxford University Press, 2015), 7 .
} 
explore these matters as a scholar of religious studies. Consequently, this project draws upon theorists who are not often referenced or engaged with in literary scholarship.

The salient disparity between any of the above approaches and my own project is the stability of the religion category. There is a tendency in many studies of religion and literature to treat religion with an assumed stability which sometimes borders on the inert. My trialectical framework serves to undercut this stasis. My chosen poets are not always deploying religion in a conscious way, and sometimes a religious allusion is simply a product of religion being a social, cultural or lexical dynamic. Therefore, while many studies of religion and literature inform and advance my approach, this thesis diverges from many of these studies and allows for the disruption of the category of 'religion'.

Critics have noted deficiencies in the three approaches outlined above. Of these, Kevin Hart, a significant and contemporary voice in the study of religion and literature, asserts that "a great deal more work needs to be done by everyone in the area". ${ }^{20}$ For Hart, studies of religion and literature often fall short because of the nature of interdisciplinary study and its tendency to try to force together "two large, unwieldy contested bodies of knowledge". ${ }^{21} \mathrm{He}$ describes most studies of religion and literature as either "critics saying things about saints Augustine or Aquinas that can only make theologians cringe" or "tenured hobbyists musing on topics such as kinesis in Smollett". ${ }^{22}$ Hart's solution is a phenomenological approach, which he demonstrates in his book Poetry and Revelation: For a Phenomenology of Religious Poetry.

\footnotetext{
${ }^{20}$ Kevin Hart, ““'Religion and Literature?” Religion and Literature 41 (2) (2009): 146.

${ }^{21}$ Ibid., 145.

${ }^{22}$ Ibid., 145-146.
} 
The aim of a phenomenological approach is to return to experience and to emphasise the epistemological over the ontological. ${ }^{23}$ This entails the bracketing of the natural attitude (the tendency to revert to an ordinary awareness of the world) in order to examine the form and content of phenomena. Hart argues that religious poems are properly understood only when we "suspend theses about the nature and acts of God and ... participate in parenthetic experience of being in relation with God". ${ }^{24}$ Questions about "whether God exists, or exists as the poet thinks" should be excluded when reading religious poetry; ${ }^{25}$ what matters are the phenomena. Additionally, Hart notes the unintentional tendency to read most poetry phenomenologically. ${ }^{26}$ A reader of poetry tends to intuitively understand that poems involve multiple logics, metaphors, symbolism, and varied definitions of words, and Hart asks for this same understanding and suspension to be brought to a reading of religious poetry. ${ }^{27}$

Hart's phenomenological reading challenges some previous projects of religion and literature. His task of exploring and elevating the articulation of religious experience in poetry has some evident advantages, the most pertinent being that it gives primacy to the religious subject matter within the poetry. However, while Hart's critiques are well aimed, his phenomenology is not the only solution to these problems, and not one that fits my own project. In part this is due to the

\footnotetext{
${ }^{23}$ The philosophical movement of phenomenology was founded in the early twentieth century by Edmund Husserl. It has been used in the study of religion most notably by Mircea Eliade and Ninian Smart. See Harry P. Reeder, The Theory and practice of Husserl s Phenomenology 2nd ed. (Bucharest: Zeta Book, 2010); Ninian Smart, The Science of Religion and the Sociology of Knowledge: Some Methodological Questions (Princeton: Princeton University Press, 1973); Douglas Allen, "Mircea Eliade's Phenomenological Analysis of Religious Experience," Journal of Religion 52 (2) (1972): 170-186.

${ }^{24}$ Kevin Hart, Poetry and Revelation: For a Phenomenology of Religious Poetry (London: Bloomsbury Academic, 2018), xii.

${ }^{25}$ Ibid.

${ }^{26}$ Ibid., 19.

${ }^{27}$ Ibid.; Derek Attridge, “"This Strange Institution Called Literature': An Interview with Jacques Derrida”, in Jacques Derrida, Acts of Literature, ed. Derek Attridge (London: Routledge, 1992), 44-45.
} 
variation between his chosen primary material and my own. Hart confines his readings to 'religious poetry' and his samples are predominantly Christian and theological. Consequently, his use of phenomenology to read this material works because the poetry is intentionally and explicitly religious. Bracketing the "natural attitude" allows Hart to study religion within the metaphor without either being questioned. In the case of this thesis, in which a wide and eclectic range of poems are examined, a phenomenological approach risks cutting off the conversations which the poetry echoes, bounces off and responds to. It is the interactions with the natural attitude which add to a reading of more secular, contemporary poetry, and my trialectical framework allows for this.

An article from the Mellon Working Group on Religion and Literature proposes seven theses for the continuing relevancy and study of literature and religion in the humanities which outline the benefits of advancing study in this area. ${ }^{28}$ An opening comment in the article suggests that the work of contemporary thinkers has revealed complex continuities between religious worldviews and secular ones which signal that the time is right for "reconceiving the conjunction between religion and literature". ${ }^{29}$ As discussed above, both Taylor and Luckmann theorise the complexities and continuities between religion and the secular, and attending to their theories highlights the significance of literature as a source for reflection on religion, even literature that does not deliberately set out to be religious. Taylor reaches this conclusion towards the end of $A$ Secular Age, when describing how literary artists disrupt the "immanent frame" of a secular world to articulate the experience of "transcendent" epiphany. To Taylor, literature is a "prime loci of expression of these newly-discovered insights; newly-discovered because people come at them from out of the immanent order". ${ }^{30}$ Similarly, Luckmann conceptualises language as a vehicle for

\footnotetext{
${ }^{28}$ Mellon Working Group on Religion and Literature, "Literature and Religion for the Humanities: Seven Theses", Religion \& Literature, Vol. 46(2/3) (2014): 151-155.

${ }^{29}$ Ibid., 151.

${ }^{30}$ Taylor, A Secular Age, 732. Nathan Scott anticipated Taylor's point in 1969 that "a radically secular literature may have a profoundly fruitful religious function to perform", see Negative Capability: Studies in the New Literature and
} 
the articulation of both the spiritual and the everyday. ${ }^{31}$ By his reasoning, language is a primary tool for the understanding of spiritual experience, particularly for modern and non-institutional manifestations of spirituality. ${ }^{32}$ Both Taylor and Luckmann open up opportunities to locate contemporary literature as a conduit for expressions of religion.

It should be noted that much of the scholarship on religion and literature gives little-to-no attention to gender. This dearth is stark, particularly in Kevin Hart's work, as his scope would allow for the inclusion of an analysis of gender in religion and poetry. Yet his poetry selection is overwhelmingly male. ${ }^{33}$ There are, of course, analyses of religious women poets, or analyses of literature by women with attention to religion. ${ }^{34}$ Additionally, one can find exercises in feminist hermeneutics using religious texts. ${ }^{35}$ However, these all differ from the intention of this thesis. Again, a conceptual split occurs in the study of women, religion and literature, where there tends to be either studies of women characters in religious texts or studies of women religious writers. A trialectical framework allows for the analysis of a wide range of literature by women poets and to

the Religious Situation (New Haven: Yale University Press, 1969), 110-111. Before Scott, Paul Tillich noted literary transcendence in the "directly religious" turn of Rainer Maria Rilke's poetry, the "priestly spirit" in Stefan George's poetry, and a “divine element” in Dostoevsky's characters, see The Religious Situation (London: Thames and Hudson, 1932), 93-101. More recently, David Tacey has noted the place of poets in the study of contemporary spirituality, see The Spirituality Revolution: The Emergence of Contemporary Spirituality (New York: Brunner-Routledge, 2004), 5557.

${ }^{31}$ Luckmann, The Invisible Religion, 54.

32 Kelly Besecke, "Seeing Invisible Religion: Religion as a Societal Conversation about Transcendent Meaning", in Religions of Modernity: Relocating the Sacred to the Self and the Digital, ed. Stef Aupers (Leiden: Brill, 2010$), 181$.

33 One chapter analyses a poem by Judith Wright but does not address gender in any substantial way. Hart, Poetry and Revelation, 141-150.

${ }^{34}$ See Things of the Spirit: Women Writers Constructing Spirituality, ed. Kristina K. Groover (Indiana: University of Notre Dame Press, 2004); Modernist Women Writers and Spirituality: A Piercing Darkness, eds. Elizabeth Anderson, Andrew Radford, Heather Walton (London: Palgrave Macmillan, 2016).

35 See The Cambridge Companion to Feminist Theology, ed. Susan Frank Parsons (Cambridge: Cambridge University Press, 2002), 171-189; Jorunn Økland, "Feminist Readings of the Bible" in The New Cambridge History of the Bible (Cambridge: Cambridge University Press, 2015), 261-272. 
pick up on presences and absences which reveal a gendered dimension to the articulation of religion in their poetry.

Resisting the split between studies of literature in religious studies, and literary studies of religion, allows both fields to contribute to this project. Studies on both sides of this split inform and influence my own, but by weighting the conjunction in 'religion and literature' I recognise the intersections and fluency between them, which encourages a nuanced and reciprocal understanding of how literature can be read with attention to religion. However, New Zealand's literary scholarship does not naturally gravitate to the inclusion of such readings, and therefore the issue of religion, New Zealand and literary scholarship must be addressed.

\section{Religion and New Zealand Literature}

A New Zealand emphasis on the primacy of the secular has affected studies on religion in New Zealand. Historian John Stenhouse has argued that the country easily adopted a "secular New Zealand thesis" which led to a "loud silence" on religion in New Zealand's historical scholarship. ${ }^{36}$ A similar silence, or absence, has resulted in a neglect of religious themes and dynamics in New Zealand literature and there are identifiable holes in New Zealand literary scholarship where religion is dismissed, muted or silent. Historical moments can help to sketch out and explain how this silence has grown. Two such moments, the literary nationalism of the cultural nationalist movement and second-wave feminism, are particularly illuminating. In each, despite major differences between them, we can observe religion being treated as difficult and thus rejected.

\footnotetext{
36 John Stenhouse, "God's Own Silence: Secular Nationalism, Christianity and the Writing of New Zealand History”, New Zealand Journal of History 38 (2004): 52. Peter Lineham has similarly noted the "absences, omissions and gross distortions [which] remain with respect to the place of religion" in New Zealand, see Peter Lineham, "The Controversy Over the Recognition of Religious Factors in New Zealand History", in The Spirit of the Past: Essays on Christianity in New Zealand History eds., Geoffrey Troughton and Hugh Morrison (Wellington: Victoria University Press, 2011), 4041.
} 
Stenhouse has argued that the literary nationalists, a group of writers who championed cultural nationalism, profoundly shaped New Zealand's historiography, the strength of their disdain for religion having established its exclusion from the historical records. Some of Stenhouse's conclusions can be extended to literary scholarship. ${ }^{37}$ The literary nationalists were made up of a number of prominent, mainly male, writers, including Frank Sargeson, Allen Curnow, A. R. D. Fairburn, R. A. K. Mason, and Denis Glover. Interestingly, many of them were raised in strongly religious families, with Curnow's father an Anglican clergyman. ${ }^{38}$ With an attitude which was "broadly secular, anticlerical [and] religiously sceptical", this group aimed to free New Zealand from the perceived stranglehold of religious puritanism. ${ }^{39}$ The literary nationalists' rejection of religious puritanism appears to have promoted and maintained a rejection of religion. The effects of this cultural reaction are recognised by some, including Stenhouse, in New Zealand's historiography, but less markedly in its literary scholarship. Jane Stafford and Mark Williams have described how, unlike in international literary scholarship, in New Zealand the disdain expressed by these modernist poets "persists". ${ }^{40}$ This has meant that the dominant reading of literature since the 1930s has been "liberal, secular and aggressively whiggish in its sense of history". ${ }^{41}$ The literary

\footnotetext{
37 John Stenhouse, “"Like Strychnine in Its Bones”? Puritanism, Literary Culture, and New Zealand History” in Journal of New Zealand Literature, 1 January (2012):150-176. It should be noted that literary nationalism is a topic that has been much discussed. For more on this area of scholarship, see John Newton's Hard Frost: Structures of Feeling in New Zealand Literature, 1908-1945 (Wellington: Victoria University Press, 2017).

${ }^{38} \mathrm{NB}$ : While a full discussion of the religious elements and issues contained within the work of the literary nationalists is not attempted in this thesis, this would be an area for further study. For example, Allen Curnow's output was Christianity-soaked throughout, despite him having lost his faith in the early 1930s. See Harry Ricketts, "Allen Curnow: A Post-Christian Poet”, JNZL Vol.36(2) (2018): 147-159.

39 John Stenhouse, "The Controversy Over the Recognition of Religious Factors in New Zealand History: Some Reflections," in The Spirit of the Past, eds. Troughton and Morrison, 46.

40 Jane Stafford and Mark Williams, Maoriland: New Zealand Literature 1872-1914 (Wellington: Victoria University Press, 2006), 16.

${ }^{41}$ Mark Williams, "Introduction," in The Source of the Song: New Zealand Writers on Catholicism, ed., Mark Williams (Wellington: Victoria University Press, 1995), 13.
} 
nationalists' influence during the 1930s meant that the tendency "to blame all the ills of society on religious puritanism" became normalised. ${ }^{42}$

The masculinity of the literary nationalists should also be noted. Stenhouse has discussed how there are many "historical links between gender, puritanism, and religion [which] remain under-explored". ${ }^{43}$ The values of the literary nationalists encouraged a male chauvinism which dismissed the "menstrual" and "feminine-mimsy" school of women poets, and characterised women writers and their work as effeminately religious and sentimental. ${ }^{44}$ Equivalents were drawn between religion, weakness and women. Three of the leading women poets at the time of cultural nationalism were Jessie Mackay, Eileen Duggan and Ursula Bethell, all of whom were publicly religious, both personally and poetically. While the misogyny of this period has been well documented and analysed, ${ }^{45}$ the connections between the literary nationalists' rejection of religion and their rejection of women poets remain under-analysed. Furthermore, it seems that the "disdain" for religion which was fostered in the period has not been interrogated with appropriate rigour in some disciplines of New Zealand scholarship. ${ }^{46}$

Cultural nationalism, and literary nationalism, can be dated from 1930 to 1970 , approximately. The second-wave feminist movement in New Zealand is often dated as taking hold in approximately 1970; thus, as cultural nationalism declined, second-wave feminism ascended.

42 Ibid., 12.

43 Stenhouse, "Like Strychnine," 153.

44 Stuart Murray, Never a Soul at Home: New Zealand Literary Nationalism and the 1930's (Wellington: Victoria University Press, 1998), 168; 48.

45 See Michael O’Leary, Social and Literary Constraints on Women Writers in New Zealand 1945-1970 (Thesis: Victoria University of Wellington, 2011).

${ }^{46}$ Kirstine Moffat is an exception, having recovered New Zealand puritan fiction - some of which is by women, see Kirstine Moffat, "Destruction, Transformation, Rebellion, Alienation: the Critique of Puritanism in pre-1930 New Zealand Novels," JNZL, Issue 16, (11) (1998): 86-96; “The Puritan Paradox: An Annotated Bibliography of Puritan and Anti-Puritan New Zealand Fiction, 1860-1940 - Part 1: The Puritan Legacy” Kōtare: New Zealand Notes \& Queries, Vol 3 No 1 (2000): 28-69. 
Despite being oppositional to much of the ideology of the literary nationalists, an anti-religious cadence also existed in the second-wave feminist movement of the 1970s. This was, perhaps understandably, a reaction against the Christian influences in first-wave feminism. The fight for suffrage had also advocated for moral reform, after-all, the Women's Christian Temperance Union was a critical institution within the wider movement. ${ }^{47}$ Thus, Australian Germaine Greer, one of the dominant second-wave feminist voices in the Southern Hemisphere, railed against the Christian leanings of her predecessors. Greer was raised in a strictly Catholic household and her forceful rejection of her upbringing suggests that the ardency of her revilement of Christianity was deeply personal as well as political. ${ }^{48}$ Greer, whose geographical closeness and tonally similar Australianisms spoke to the New Zealand feminist movement, ${ }^{49}$ advocating against Christianity, gentility and purity. ${ }^{50}$ She freely expounded on the faults in the work of the first-wave feminists who, she claimed, had "failed" to overthrow God, marriage, the family, private property and the state. ${ }^{51}$ The New Zealand feminists of the 1890s had marched under the banner "For God, Home and Humanity", but much of the second-wave feminist movement dismissed Christianity as patriarchal and limiting for women. ${ }^{52}$ By the 1970 s, the "Home" of the first-wave feminists' banners was read as "household", viewed by many as a prison of domestic subordination. "Humanity" was seen as a placeholder for "men", which did not safeguard the interests of women. ${ }^{53}$ And "God" was

\footnotetext{
${ }^{47}$ Barbara Brookes, A History of New Zealand Women (Wellington: Bridget Williams Books, 2016), 344.

${ }^{48}$ See Christine Wallace, Germaine Greer, Untamed Shrew (Boston: Faber and Faber, 1998), 10-11.

${ }^{49}$ Brookes, “A Germaine Moment: style, language and audience," in Disputed Histories: imagining New Zealand's pasts, ed. Tony Ballantyne and Brian Moloughney (Dunedin: Otago University Press, 2006), 196.

${ }^{50}$ Brookes, A History, 342.

${ }^{51}$ Germaine Greer, The Female Eunuch (London: Paladin, 1971), 11.

${ }^{52}$ Laurie Guy, Shaping Godzone: Public issues and church voices in New Zealand 1840-2000 (Wellington: Victoria University Press, 2011), 417.

${ }^{53}$ Brookes, A History, 344.
} 
a patriarchal figurehead of a powerful and controlling institution. ${ }^{54}$ Interestingly, although the second-wave feminists in large part rejected Christianity, much of the rhetoric at the time was inflected with spiritual diction, with Greer described as a "high priestess" of women's liberation. ${ }^{55}$ With regards to traditional religion, however, Greer's critique, and others like it, continued to shape the mainstream discourse.

Since the 1970s, the time period at which this thesis begins, there has been a gradual awareness within the New Zealand literary sphere of the need to readdress the under-representation and misogyny towards women writers inherited from the literary nationalists. In fact, it was International Women's Year, 1975, which led to and saw the publications of first collections by a number of New Zealand women poets, some of whom are cited in the coming chapters.

Nevertheless, the dominant attitudes to religion in New Zealand literature have remained largely unexamined. James K. Baxter is an exception to the norm. Baxter, whose poetry was heavily influenced by his Catholicism and life at the Whanganui commune Jerusalem, is one of the few poets whom it is deemed acceptable, and even necessary, to analyse in terms of religion. ${ }^{56}$ The emphasis on religion in Baxter's work has not opened up space for a dialogue on religion in New Zealand literature generally, but rather placed him at the apex of any such contribution. My choice

\footnotetext{
54 Ibid.

55 Mary Spongberg, “If She's So Great, How Come So Many Pigs Dig Her? Germaine Greer and the Malestream Press". Women's History Review 2 (3) (1993): 407; The rhetoric surrounding Greer is in keeping with projects beginning in the 1970s which rejected traditional religious institutions but aimed to reclaim the language and status of the goddess. With Greer, this language is seen sharply in a political context. See Theresa Garner, "Germaine Greer back at scene of dubious crime”, New Zealand Herald, 2003; Brookes, “A Germaine Moment”, 198; Eric Heath, [cartoon], The Dominion, 9 March 1972.

56 In art, Colin McCahon is Baxter's equivalent, and is equally accepted as a painter whose work is influenced by religion. It is not the place of this thesis to expound on this, but New Zealand's reception of visual art has a similar blind spot when it comes to religion. Interestingly, Rita Angus' goddess paintings do not appear to have been given space in an analysis of religion in New Zealand painting, despite there being clear connections between Angus' works and the goddess revolution of the later twentieth century.
} 
of women poets enables us to escape the long shadow of Baxter, who can threaten to overwhelm discussions on religion in New Zealand literature. ${ }^{57}$

Apart from Baxter, while religious motifs are not completely ignored, they are commonly dismissed. An example of this is a review of Robin Hyde's The Book of Nadath. ${ }^{58}$ The title suggests the biblical form it borrows from, and it is written in the voice of a fictional false prophet, Nadath, who, throughout fourteen sections, probes the question of how to articulate crises. Written by the same poet who used the story of Jacob and Esau to illustrate the injustices at Bastion Point, ${ }^{59}$ this poem seems ripe for examination of religious form and motif in the politics and poetics of a prominent New Zealand writer. But such discussion is surprisingly limited. Jane Stafford's review of The Book of Nadath sidesteps the religious factor, stating that "any nineteenth or twentiethcentury author who configures their work in terms of scriptural cadences is surely working out of [William] Blake". ${ }^{60}$ Certainly Blake's influence is wide and long-lived, but such easy dismissals appear symptomatic of a wider trend. More importantly, such glib erasures ensure religious themes and metaphors are left under-analysed. The presumption of poets' secularity ensures that when religious themes do emerge a dominant tendency is to ignore or diminish their salience.

There are, of course, exceptions to this, mostly to be found within literary scholarship, rather than religious studies. Mark Williams is a notable example. Most recently, in 2018, Williams and Christine Lorre-Johnston co-edited an issue of the Journal of New Zealand Literature on

\footnotetext{
${ }^{57}$ Paul Morris, Harry Ricketts and Mike Grimshaw, "Introduction” in Spirit in a Strange Land: A Selection of New Zealand Spiritual Verse, eds. Paul Morris, Harry Ricketts and Mike Grimshaw (Auckland: Godwit, 2002 ), 13.

58 A long-form poem Hyde wrote in 1937, and posthumously published by Michelle Leggott in 1999, see Robin Hyde, The Book of Nadath, introduction and notes by Michele Leggott (Auckland: Auckland University Press, 1999).

59 This is in reference to Hyde's poem "Naboth's Vineyard at Orakei." See Laurie Guy, Shaping Godzone: Public Issues and Church Voices in New Zealand 1840-2000 (Wellington: Victoria University Press, 2011), 344-346.

60 Jane Stafford, “Review: The Book of Nadath,” Kōtare 2 (1999): 83.
} 
"Afterlives of the Bible". ${ }^{61}$ Yet even in this volume the prefix "After" suggests that the relevance of religion in New Zealand literature is posthumous. ${ }^{62}$ The word choices used by the authors in this same issue are revealing. Harry Ricketts, in an analysis of Allen Curnow, notes his own religious reading as "unfashionable", ${ }^{63}$ and John Dennison describes an "awkwardness" in New Zealand which arises when the name Jesus is said "in any other register than profanity" ${ }^{64}$ Dennison's "awkwardness" is perhaps the word which best describes the treatment of religion in New Zealand literary scholarship. Religion's "awkwardness" and "unfashionable" status, promoted by the literary nationalists and reconfigured in second-wave feminism, remains.

Investigation of religion in New Zealand literature continues to be illuminating, but to do so we need a sufficiently nuanced and robust analytical approach. The stasis of the religion category in studies of New Zealand literature, as discussed above, is what my trialectic framework aims to disrupt. In New Zealand scholarship, the religion category is not just inert, it is almost entirely absent. While awkwardness about religion is evident in the literary scholarship, close attention to the literature itself tells a different story. This is not to say that New Zealand women's poetry since the 1970s explores it in easy and uncomplicated ways. Rather, religion is a dynamic element, one

\footnotetext{
61 “Afterlives of the Bible”, ed. Mark Williams and Christine Lorre-Johnston, Journal of New Zealand Literature (JNZL) Vol.36(2) (2018).

${ }^{62}$ For other studies on, or which mention, religion and New Zealand literature, see Trevor James, "Religious Awareness in New Zealand poetry: A Problem for the Imagination” World Literature Written in English, Vol. 24 , No. 2 (1984): 429-433; Spirit in a Strange Land, eds. Morris, Ricketts and Grimshaw (Auckland: Godwit, 2002); Harry Ricketts, "Spiritual Poetry" in 99 Ways in to New Zealand Poetry, Paula Green and Harry Ricketts (Auckland: Vintage, 2010), 348-355; Geoffrey Troughton's New Zealand Jesus: Social and Religious Transformations of an Image, 18901940 (Bern: Peter Lang, 2011) notes the poetry of Eileen Duggan and Ursula Bethell in connection with religion - pp. 70-71, 134; Mark Williams ““When You're Dead You Go on Television': Sex, Death and Household Objects in Some New Zealand Poetry”, Sport 42 (2014): 149-173; Kirstine Moffat, “The Manliest and Noblest of All Pursuits and Professions': Two Preacher Novelists" in Sacred Histories in Secular New Zealand, eds. Geoffrey Troughton and Stuart Lange (Wellington: Victoria University Press, 2016), 123-138. Also

${ }^{63}$ Harry Ricketts, “Allen Curnow: A Post-Christian Poet”, JNZL Vol.36(2) (2018): 147.

64 John Dennison, "The seam of light: The Bible, the Gospel Hall, the Poet” JNZL Vol.36(2) (2018): 161.
} 
which is picked up, transformed, resuscitated, and criticised, over a wide variety of poems by many poets since the 1970 s.

\section{Selection and Outline}

This thesis involved selecting poetry from a range of authors, gathered from a comprehensive reading of New Zealand women poets from 1970 to 2019. I did not begin with a predetermined selection of poets to choose from, and insofar as is possible I have sought to let the material lead the way. Thus, I have employed an environmental scan, identifying trends, themes and images that are recurrent and weighty, and have selected poems for analysis accordingly. ${ }^{65}$

Initially, I explored two other possible methods of selection. The first was to use an anthological method, selecting poetry only from anthologies, and the second was to select from award-winning poetry. After exploring both, I decided that either one, and in fact any selection process which employed rigid limits, would be unhelpfully restrictive. Anthologies would render a sample of poems representative of editorial choice, and some anthologies, particularly those published in the twentieth century, include only a handful of women poets. ${ }^{66}$ Although the environment for women poets has improved markedly, it is difficult to find a New Zealand anthology that equally represents both genders. Such under-representation of women poets suggests that anthologies would have yielded a narrow range of poems to work with. Also, the tendency to characterise New Zealand as secular means that more confessional and obviously religious strands of New Zealand women's poetry tend not to be anthologised. This is not to say that none of the

\footnotetext{
65 "Environmental Scan" is a term predominantly used in market and business research. In this thesis I am borrowing it to describe a literature review which aims to procure an extensive grasp of the poetry "environment".

${ }^{66}$ In Vincent O’Sullivan's anthologies of 20th century New Zealand poetry (1970, 1976, 1987), Miriama Evans, Harvey McQueen and Ian Wedde's The Penguin Book of Contemporary New Zealand Poetry (1989), and in Jenny Bornholdt, Gregory O'Brien and Mark Williams' New Zealand Poetry in English (1997) about a third of the contributors are women.
} 
poems in New Zealand anthologies afford any religious or spiritual reading, because several such poems featured in anthologies are included in this project. It became apparent, however, that some poets whose work was central to the concerns of this thesis would not have been addressed. These concerns would also have arisen using award-winning work as a selection process, since there was a veritable dearth of award-winning women poets before the twenty-first century. Additionally, particularly in award-winning poetry, there are few Māori and Pacific women poets to select from. All these factors contributed to my settling on conducting an environmental scan.

An environmental scan is akin to a literature review, but with the intention of sifting through the material to find applicable primary sources, and recurrent and provoking thematics. My initial ventures into selection, with the anthologies and award-winning work, provided a scope of the main territory; however, after having grasped what this terrain provided, I realised its limitations. An environmental scan enabled me to go after a wider field. While this thesis does not represent an exhaustive or definitive sample of New Zealand poetry, the environmental scan has been as comprehensive as possible.

Initially I included digital poetry in the environmental scan, reading online poetry journals, blogs and individual poets' sites ${ }^{67}$ However, I subsequently decided to exclude poetry which has been exclusively digitally published. This is in part because digital publication has only been accessible for, approximately, the last two decades and as my periodisation begins in 1970, digital poetry may have skewed or distorted the methodological process and eventual poetry selection. Additionally, I think digitally published poetry deserves separate and more targeted attention. A project into religion in digital poetry would be an interesting and important additional study. ${ }^{68}$

\footnotetext{
${ }^{67}$ By digital poetry, I mean poetry published only online in the digital space. This is also known as electronic poetry. ${ }^{68}$ See New Zealand Electronic Poetry Centre http://www.nzepc.auckland.ac.nz (Accessed from 13 April 2019).
} 
The environmental scan involved the collation of a list of New Zealand women poets and then reading as much of their poetry as possible. My collation followed three different pathways. The first of these was gathering a list of names from poetry collections which were easily accessible through library resources and currently in-print. Additionally, five anthologies proved useful for gathering poets' names. One of these was Spirit in a Strange Land which, along with its sequel Spirit Abroad, are the only New Zealand anthologies with a specifically spiritual or religious focus. The other three were women's poetry anthologies, Private Gardens (1977), Yellow Pencils (1988) and Wild Honey (2019). Collectively these provided a valued overview of the literary history of women poets, some of which have not been published anywhere else. In my first chapter I explore the commentary afforded by these volumes to a greater degree, but in terms of the selection process, these anthologies provided a list of New Zealand women poets, ranging from c.1970 to 2018, which greatly aided the selection process.

The second pathway was accessing archival material from the National Library of New Zealand, using both online databases and microfilm, in order to gain a broader overview of New Zealand women's poetry and particularly work which had not been published in poetry collections or was out of print. I focused my search on magazines and literary journals. Of these, the feminist magazine Broadsheet proved to be the most useful. ${ }^{69}$ Broadsheet, produced by the Auckland Women's Liberation publications subcommittee, was established in 1972 and ran until 1997 with the aim of combining public education with political action. Poetry, almost exclusively by women, appears consistently throughout Broadsheet's twenty-five-year run, some of which cannot be found elsewhere. Poetry publication within Broadsheet was encouraged early on by a women's poetry competition, which aimed to support budding poets within the feminist movement, with the winners

\footnotetext{
${ }^{69}$ Other publications accessed through The National Library and archival material, but not included in this thesis, include Vashti's Voice, Above Rubies, New Zealand Women's Weekly, Salient and The Circle.
} 
and notable entrants published in the magazine. ${ }^{70}$ Additionally, poetry was sometimes featured as part of a book review, or simply placed between articles and columns, often credited but sometimes anonymous, and frequently the writers were not known poets. Some issues featured poets and poetry as part of the week's subject matter. Notably, the "Women in the Arts" issue included an article by Riemke Ensing on women writers, and a piece on New Zealand poet Jan Kemp and her poem "Against the Softness of Women" ${ }^{71}$ Reading Broadsheet, among other publications, gave a broader understanding of the poetry environment. ${ }^{72}$

My third pathway was focusing on the output of certain publishing companies and online sources, which broadened the environmental scan. These included Spiral, Godwit Press, Caveman Press and Huia Publishers. Focusing on publishing companies allowed me to gather names of women poets, including some who were less well-known or no longer in print. Spiral proved to be particularly productive. Formed in 1973 as a "book publisher of last resort" and as a corrective to decisions made in publishing which "resisted commitment to work which reflected realities unfamiliar or unattractive to them, especially those of Māori and other women", their list of published works provided some names which I had previously not come across. ${ }^{73}$ Additionally, Paula Green's New Zealand Poetry Shelf, an online source, provided an archive of reviews of more recently published poetry, clustered around the 2000 to 2019 period. These three pathways produced an extensive list of poets and poetry, the result of which was a selection of poetry examples from nineteen women poets which provide my main source of material.

\footnotetext{
${ }^{70}$ Broadsheet July 1973 (No.11): 6.

${ }^{71}$ Broadsheet September 1974 (No. 22).

72 Broadsheet revealed the body and domestic care to be prominent themes, and Rachel McAlpine was a frequently cited poet. See "Women and Religion" (Broadsheet No. 25 December 1975); Broadsheet Special Issues: Writings from the Women's Movement (Broadsheet August 1975); "Body and Soul" (Broadsheet No. 206 1995); "Motherhood: Hating it and Loving it" (Broadsheet No. 135 December 1985).

73 “Spiral” New Zealand History https://nzhistory.govt.nz/women-together/spiral (Accessed 25 May 2019).
} 
I adopted a thematic structure for the project, focusing on three different themes which emerged through the environmental scan: domesticities, body and flesh, and whenua/land. These themes, though by no means comprehensive, were identified as important for a number of reasons. First, they were all recognisably recurrent. Second, each was analytically productive, and related to theories, concepts and conversations that I could identify in scholarship and criticism; socially and culturally each has resonance. Lastly, each of these themes speaks to the context of women poets writing in New Zealand since the 1970s.

My opening chapter evaluates religion and the domestic theme in New Zealand women's poetry. A theme which carries a discordant and difficult history, domesticity is rarely awarded any considerable value. In this first chapter I explore how, when analysed with attention to religion, the domestic is illuminated as a sphere punctuated with religious experience. Opening up the domestic theme to include poems which are bleak and threatening, I argue that attention to the mundane and profane of the domestic sphere reveals a religious domestic over a range of different examples.

My second chapter discusses the motifs of body and flesh, which began to increasingly surface in New Zealand women's poetry in the latter half of the 20th century, aided by second-wave feminism. Applying Mayra Rivera's theory of somatic and carnal poetics, I examine the interweaving of religious and spiritual language with body-words. Both somatic and carnal poetics indicate different styles in which New Zealand women poets represent the body and the flesh with religious imagery.

In my third chapter, I take whenua/land, one of the more prominent tropes in New Zealand literature. The poetry examples in this chapter reveal a landed religio-spiritual poetics in which biculturalism and gender play vital roles. In this chapter, the poetry examples model how New Zealand women poets negotiate between different mythological and theological frames of reference when writing about land. This chapter evidences a bicultural poetry built on Bethellian and whenua 
traditions and suggests that landed poetry by New Zealand women gravitates towards responses to existential events.

This thesis reveals the remarkable persistence of religion in New Zealand women's poetry since the 1970s. This persistence is not limited to just 'religious poetry' but rather can be found across a wide range of themes, including those selected for this thesis: domesticities, body and flesh, and whenua/land. The analysis that follows exemplifies how studying poetry in New Zealand religious studies, and studying religion in New Zealand literature, reveals spaces in which New Zealand's women poets have been working for decades. Attending to these spaces enriches our understanding of both religion and literature in New Zealand. 


\section{CHAPTER ONE}

\section{DOMESTICITIES}

According to Germaine Greer, writing by women has long been thought of as belonging to the dialect of the demotic, and writing by men to the upper class and arcane. ${ }^{74}$ Historically, women did not commonly assume the postures of writers of grand scope because the chances of becoming so were slim to non-existent; instead they tended to record "the minutiae of the joys and sorrows of ordinary people". ${ }^{75}$ These minutiae are often categorised as 'domestic'. Building on scholarship related to the domestic, this chapter explores poetry which illuminates the religious domestic in New Zealand women's literature. The religious domestic is not one-dimensional, but the reception of the domestic theme in women's literature has led to a flattened perception of what domesticity entails. In this chapter I expand the confines of domesticity and attend to a variety of domestic experiences. I argue that the domestic provides a potent and provoking entrance into religion in New Zealand women's poetry, showing it to be a theme which affords rich religious and spiritual readings.

In 1980, Illich coined the term "shadow work" to describe the emotional and laborious work "usually labelled "family life"" ${ }^{76}$ He sought to shed light on the tasks that take place "in the shadows" and the work which is "marginal [and] difficult to identify". ${ }^{77}$ By drawing attention to its shadowiness, Illich pleads for new attention to this vital cultural space. The domestic penumbral phrase acutely identifies how domesticity is socially, politically and rhetorically placed on the edges

\footnotetext{
${ }^{74}$ Germaine Greer, “The Tulsa Center for the Study of Women's Literature: What We Are Doing and Why We Are Doing It”, Tulsa Studies in Women's Literature, Vol. 1, No. 1 (Spring, 1982): 5.

75 Ibid.

${ }^{76}$ Ivan Illich, "Shadow Work" Philosophica 26 (2) (1980): 8.

77 Ibid.
} 
of society, occluded from view, despite its fingerprints being on almost all facets of our lives. ${ }^{78}$ "Shadow work" is now a term predominantly used in economics, but Illich's coinage is poetic: through it we can see how domesticity lingers in doorways, and how its darker contours, such as violence, oppression and poverty, may be sustained because it remains in the shadows. Therefore, I deploy Illich's image of shadows in this chapter to illuminate the marginality of domesticity. Religion and spirituality are similarly shadowed subjects in New Zealand literary scholarship, and yet religious and spiritual words, images and descriptions permeate the domestic in New Zealand women's poetry. I examine these shadowy spaces where domesticities and religion meet.

In this chapter, I explore how the domestic theme engages with religion across several different homely domains. In the first section, poems by Airini Beautrais and Cilla McQueen, present examples of religious motifs within domestic spaces. In the second section, the anecdotal poetry of Jenny Bornholdt and Martha Morseth sees the shadowy domestic space intertwined with religious language. In Bornholdt, moments of transcendence both light up and confuse the domesticity of parenting. In Morseth, domestic fatigue is moderated through Christian imagery as descriptions of old age are woven with the language of liturgy. The last two examples, poems by Meg Campbell and Tusiata Avia, broaden the parameters of the domestic theme, allowing for a wider exploration of religion and spirituality in domesticity within New Zealand women's poetry. These examples move further into the shaded margins by focusing on elements of domesticity which are not always labelled as such. Campbell's poem is laced with Christian prayer but threatened with a frustrated exhaustion which hints at domestic oppression. Avia's poem "This is a Picture of my House" is titularly an epitome of domesticity, but in fact eviscerates any easy association of Home with safety or comfort. It articulates a domestic spirituality which sees the speaker transcend domestic violence through spiritual imagery.

78 Ibid., 7-8. 
It is important to state at the outset of this chapter that my selection of domesticities as a theme is not an expression of nostalgia for a past in which women were condemned to the home. Such representation should not be regarded with a fondness which disregards the realities of domestic labour and care. Exploring domesticity by discussing its presence in poetry does not validate the oppression many women experience in domestic circumstances. It may even go some way to opening up space to interrogate and question the gendered assumptions which undergird these spatial logics. But if domesticity is ignored in the present, we also ignore the pasts of women whose lives consisted of domestic obligation. Moreover, there are a raft of subjects attached to domesticity which deserve critical attention, including equal work opportunities, child care, parental rights, caring for the elderly and disabled, and unpaid labour. The domestic provides extensive resources that women have used in their work.

I am encouraged down this path by Paula Green, who has described domestic poetic contexts as "fruitful architectural entrances into a consideration of the way poetry is born out of domesticity". ${ }^{79}$ The domestic circumstances presented through the examples in this chapter are varied, as domestic experience is not uniform. In Māori and Pasifika contexts, for example, domesticity can mean something very different to that of Pākehā. ${ }^{80}$ Similar disparities apply to class and socio-economic divisions, and a number of other qualifiers. I recognise that I will only be able to touch on a limited number of poems, perspectives and experiences of domesticity. Every one of these poems could prompt further explorations of the theme in New Zealand poetry specifically and in New Zealand women's literature more broadly. ${ }^{81}$

\footnotetext{
${ }^{79}$ Paula Green, "The Kitchen” in 99 Ways, 210.

${ }^{80}$ For more on domesticity, religion and Pasifika communities, see Keiti Ann Kanongata'a, "Domestic Theology" The Pacific Journal of Theology Series II, 15:73-75.

${ }^{81}$ While I do not cover either poet in this chapter, I want to acknowledge the work of Fleur Adcock and Lauris Edmond. Both women poets cleared a space for the domestic in New Zealand poetry within the periodisation of this thesis, and the spiritual qualities of their work is worth further study. See Fleur Adcock, Poems1960-2000 (Newcastle upon Tyne:
} 


\section{Religion and Domesticity}

The salience of the domestic thematic is seldom given weight. It seems as if domesticity has inhabited a place so intrinsic that it is often taken for granted or discounted as dated and female. Gender studies are committed to recovering the personal narratives of women in order to retrieve and reinstate women's agency in the historical records. ${ }^{82}$ Despite this, feminist historians have grappled with how to write about those experiences which ground women in the home without seeming to couple female existence with domesticity. ${ }^{83}$ However, the reality is that domesticity has fallen disproportionately to women, meaning that it is a gendered subject. ${ }^{84}$ Barbara Brookes, a New Zealand historian, has tackled this issue and emphasises the importance of making the domestic visible, rather than avoiding it, because through domesticity we are be able to see "the complexity of social change". 85

Attention to this social change shows that there are connections between the shadowiness of domesticity and the status of Christianity. The scholarship of Emily Abel and Callum Brown suggests links between the decreasing respect for women's domestic roles and the increasing popularity of secularisation theory. In New Zealand, where Christianity was the dominant religion, Christianity both prescribed and valued women's roles. Church discourse placed a strong emphasis

\footnotetext{
Bloodaxe, 2000) - particularly her poem "For a Five-Year-Old", p. 21; Lauris Edmond, In Middle Air: Poems (Christchurch: Pegasus Press, 1975); __. Late Song (Auckland: Auckland University Press, 2000).

82 Barbara Brookes, Jane McCabe \& Angela Wanhalla "Introduction" in Past Caring? Women, Work and Emotion, eds. Barbara Brookes, Jane McCabe and Angela Wanhalla (Dunedin: Otago University Press, 2019), 10.

${ }^{83}$ Brookes, "Contextualising Caring in New Zealand” in Past Caring? 17-23.

84 Ibid.

${ }^{85}$ Ibid., 32.
} 
on the importance of women's domestic contributions as central to family, communal and religious life.

Historian Emily Abel has explained how historically the three major components of women's caring were "instrumental, spiritual and emotional". ${ }^{86}$ By "spiritual" she refers to how life events, including sickness and death, "were regarded as religious as well as medical". ${ }^{87}$ Although medical care was valued, European society also saw Bible reading and prayer as important elements in the care of others. However, this respect for domestic care has broadly lost traction in the Western world. The drop in the status of domesticity and women's roles in the home can be seen as connected to a declining regard for the church. Secularisation meant that the domestic spiritual and emotional roles bequeathed to women, and which were encouraged by Christian doctrine, have been eclipsed.

Callum Brown's work on secularisation in Britain supports these links between the domestic and secularisation. Brown has demonstrated that women remained at the heart of organised religion in the 1950s, but in the 1960s, with a growing emphasis on self-fulfilment, church involvement markedly declined ${ }^{88}$ Brown tracks how the cultural narrative of women gaining fulfilment through home and family fell away, and the burdens of the family and marriage became the focus of feminist critique. ${ }^{89}$ Women's magazines began paying less attention to contentment in the domestic

\footnotetext{
${ }^{86}$ Emily K. Abel, Hearts of Wisdom: American women caring for kin 1850-1940 (Cambridge, Mass.: Harvard University Press, 2000), 60.

${ }^{87}$ Ibid., 263.

${ }^{88}$ Callum Brown, The Death of Christian Britain: Understanding Secularisation 1800-2000, 2nd ed (London: Routledge, 2009), 170-192.

${ }^{89}$ Ibid., 176-180.
} 
sphere and instead placed an increasing emphasis on women's careers. ${ }^{90}$ According to Brown, the 1960s saw the gradual erasing of Christianity from everyday culture and from family life. ${ }^{91}$

If Brown's thesis generalises to New Zealand, assuming some reasonable levels of national difference, then the collapse of regular church attendance can be seen as the catalyst for the disruption and devaluation of the domestic. ${ }^{92}$ As secularity took hold, respect for domesticity dissolved and both domesticity and traditional religion were relegated to being shadow subjects. This connection between secularisation and declining regard for domesticity in the 1960s did not, however, result in the demise of either religion or domesticity. Both were occluded and this can be identified in the reception of the poetry of New Zealand women.

\section{The Domestic and New Zealand poetry, c.1930-2019}

Prevalent attitudes to domesticity as a poetic theme in New Zealand have been historically pejorative, with, predominantly male, critics opining that women poets have flogged the theme ad nauseam but have never succeeded in rendering it interesting. ${ }^{93}$ Criticism of the domestic in New Zealand women's poetry grew in the 1930s, the period in which the literary nationalists emphasised anti-puritanism, anti-clericalism, masculinity and patriotism. ${ }^{94}$ A. R. D. Fairburn's prose piece, "The Woman Problem", reflects dominant attitudes at the time, in its declaration that women "really have no desire for $[\ldots]$ freedom" and their minds are "not designed for the purpose of making judgements

\footnotetext{
${ }^{90}$ Ibid., 79-80, 177-178.

${ }^{91}$ Ibid., 2.

92 Geoff Troughton has previously explored the relevancy of Brown's thesis for New Zealand. See, Geoff Troughton "Anti-Churchianity, Discursive Christianity, and Religious Change in the Twentieth-Century" The Journal of New Zealand Studies; No 17 (2014): 93-106.

${ }^{93}$ Paula Green notes the extensive backlash received after publishing her first poetry collection, Cookhouse, see Paula Green, Wild Honey: Reading New Zealand Women's Poetry (Auckland: Massey University Press, 2019), 162-164; 510.

94 Stenhouse, "'Like Strychnine,” 152-3; 158.
} 
on matters that call for objective consideration". ${ }^{95}$ This attitude saw him christen New Zealand women poets the "menstrual school" of poetry. ${ }^{96}$ Denis Glover's 1937 poem The Arraignment of Paris mourns how "New Zealand literature distils / An atmosphere of petticoats and frills". ${ }^{97} \mathrm{He}$ categorises the poetry of women as "very much the female gender / Preferring little gems and safe agenda / To great flawed stones, and a poetic splendour." ${ }^{98}$ I read "little gems and safe agenda" as a synonym for the domestic. Views such as Fairburn and Glover's became more subliminal and less explicit with time, but the sentiment still remained. Arthur Baysting, editor of the 1973 anthology The Young New Zealand Poets, commented that most of the work he received from women was "of a two-dimensional quality - too often clichéd and overly sentimental”, and those women poets who did manage to "communicate genuine emotion showed little control over their craft". 99

"Sentimental" has been recognised as another common synonym for domestic, particularly when used in reference to women's writing. In his anthology of eighteen poets, Baysting included just one woman. Three years later Sam Hunt, in a review of nine poetry collections by women, implied that the lack of publication of women poets was only because "until very recently the scene was a fairly dismal and discouraging one". ${ }^{100}$ Such opinions as these are now broadly denounced, but it is questionable whether the core of the sentiment has entirely disappeared.

\footnotetext{
95 A. R. D. Fairburn, The Woman Problem \& Other Prose (Auckland: Blackwood and Janet Paul Ltd., 1967), 13-18.

96 Peter Whiteford, “Eileen Duggan, 1894-1972”, in Paul Millar, Jane Stafford \& Mark Williams, eds. Kotare 2008. Special Issue - Essays in New Zealand Literary Biography Series Three: 'The Early Poets'. (Accessed 9 May 2019). https://viewer.waireto.victoria.ac.nz/client/viewer/IE908016/rep/REP908073/FL908074/t1/t1-g1$\underline{\mathrm{t} 13 ? \mathrm{dps} \text { dvs }=1563234762291 \sim 715}$

97 Denis Glover, The Arraignment of Paris. Christchurch: The Caxton Press, 1937, 1.

${ }^{98}$ Ibid., 5 .

99 Arthur Baysting, "Introduction” in The Young New Zealand Poets ed. Arthur Baysting. Auckland: Heinemann Educational Books 1973, 4; sentimental is a common synonym for domestic, see Susan Fraiman, Extreme Domesticity: A View from the Margins (New York: Columbia University Press, 2017), 69-71.

${ }^{100}$ Sam Hunt, "Pieces of Nine”, New Zealand Listener (April 17, 1976): 32.
} 
The reception of women poets in recent decades has been more encouraging, but Hugh Roberts' 2010 article, "Is it a poem or a blog?" raises questions as to whether the views of the literary nationalists remain, perhaps somewhat diluted, in critical approaches to women's poetry. Roberts reviews four collections, assessing whether the poetry goes beyond "exercises in Higher Blogging". ${ }^{101}$ His criticism is articulate, but what goes unstated - though retrospectively is glaring is that the four collections are all by women writers. While devoid of the blatant misogyny of the previous examples, Roberts' summation of “free-verse ruminations on Stuff That Has Happened To Me Lately" only uses examples from women's poetry and is thus an opaque criticism of the minutiae of domestic femininity. ${ }^{102}$ It is not unsurprising that the dominance of these attitudes has relegated the domestic category to a pejorative. Just as societal changes moved the practical day-today of domesticity into the shadows, in New Zealand literary circles such attitudes created in a general aversion to the subject matter.

Three anthologies of New Zealand women's poetry, published across the timespan covered in this thesis, can be read as a microcosm of responses by women poets to the criticism of the domestic in poetry. Paula Green's recent publication of her 2019 anthology-cum-personal-study, Wild Honey, is the most recent, and joins two much earlier volumes: Riemke Ensing's Private Gardens (1977) and Lydia Wevers' Yellow Pencils (1988). These three anthologies were integral to

\footnotetext{
101 Hugh Roberts, “Is it a poem or a blog?”, The New Zealand Listener, 31 July 2010, https://www.noted.co.nz/archive/listener-nz-2010/is-it-a-poem-or-a-blog/ (Accessed 6 June 2019).

102 Ibid; Patrick Evans' article “Spectacular babies", on New Zealand writing and the Manhirean school, has some comparably misogynistic tones, and emphasises that successful New Zealand writers tend to be "female and attractive", see Patrick Evans, "Spectacular babies: The Globalisation of New Zealand fiction”, World Literature Written in English, Vol.38(2) (2000): 94-109. Roberts discusses Evans' article himself in "New Zealand Literature in the Program Era, or, the Spirit of Nationalism Past" in A History of New Zealand Literature, ed. Mark Williams (New York: Cambridge University Press, 2016), 374-387.
} 
my selection process, but here I focus on the commentary afforded by the three respective editors. $^{103}$

As an early entrant into New Zealand women's poetry anthologies, Ensing's introduction to Private Gardens is understandably guarded, laced with caution and diplomacy which sometimes borders on the contradictory. Her tone is sensitive to criticism, and she describes the category of women as only "arbitrary" and anthologies as "no more than a collection of poems from a particular area or period or group of people, and as such [women] is simply a classification of convenience". ${ }^{104}$ She describes how very few New Zealand women poets would "put poetry first, domestic commitment second", and characterises the poetry of Private Gardens as "polite" with a "tendency towards the inoffensive, the safe, the pleasant and clean ... the New Zealand woman poet is still the 'Angel of the House' and the strident voice is largely absent". ${ }^{105}$ Thus, Ensing aligns her anthology's poetry with the domestic category.

A decade after Private Gardens, Wevers compiled Yellow Pencils. Addressing Ensing's difficulties over categorisation, Wevers comments that nobody "writing now of an anthology of women poets would introduce it as a classification of convenience". ${ }^{106}$ Yellow Pencils strips away the politeness of Ensing's Private Gardens, and the unwillingness to tackle anything unpleasant or unclean is replaced by themes including "menstruation, sex, particularly featuring women as active lovers, pregnancy, rape, and incest". ${ }^{107}$ Next to Wevers' frank introduction, Ensing's "classification

\footnotetext{
${ }^{103}$ It should be noted that these are not the only anthologies of New Zealand women's poetry, but they are some of the most extensive.

104 Riemke Ensing, "Introduction", in Private Gardens: An Anthology of New Zealand Women Poets (Dunedin: Caveman Publications, 1977), 10.

105 Ibid., 12

${ }^{106}$ Lydia Wevers, "Introduction”, in Yellow Pencils: Contemporary Poetry by New Zealand Women (Oxford: Oxford University Press, 1988), xvii.

${ }^{107}$ Ibid., xxii.
} 
of convenience" reads as minimisation and defence. Far from her forerunner's apologetic tone, Wevers declares that in this new anthology "anger and hostility" are very present. ${ }^{108}$ Where Ensing averted the gaze from the feminist, the impolite and the overly emotional, Wevers champions that which may be typified as shocking or distasteful. She notes the differences between her and Ensing's anthologies, ${ }^{109}$ suggesting that women poets have moved away from domesticity towards a more liberated poetics. However, the subjects Wevers identifies in Yellow Pencils can still be regarded as thoroughly domestic. Themes including "menstruation, sex ... pregnancy, rape, and incest" occur in domestic situations, although they have not necessarily been accepted as part of an idealised domestic sphere. The "clean[ness]" which has imbued domestic poetry by dint of gender stereotypes did not permit these darker themes to be fully categorised or explored as domestic, which creates further shadows around the domestic sphere.

The most recent collection of women's poetry, Wild Honey, has been described as "noisy, refreshing and proudly anchored in the domestic". ${ }^{110}$ Green, who quickly identifies the criticism of the tedium of domestic writing, aims to give light to women's poetry in all its domesticity. She shapes the book into a metaphorical house, with the chapters taking the names of rooms or items (study, mirror, kitchen, sickbed, etc.). Green acknowledges the negative attitudes towards the theme, and attributes this to sexism, ${ }^{111}$ as well as to the effects of the women's liberation movement and its breaking of the kitchen-bound, female-role domesticity (which she commends as "utterly necessary”). ${ }^{112}$ This latter point sees Green's thinking align with Brown's thesis. Green suggests

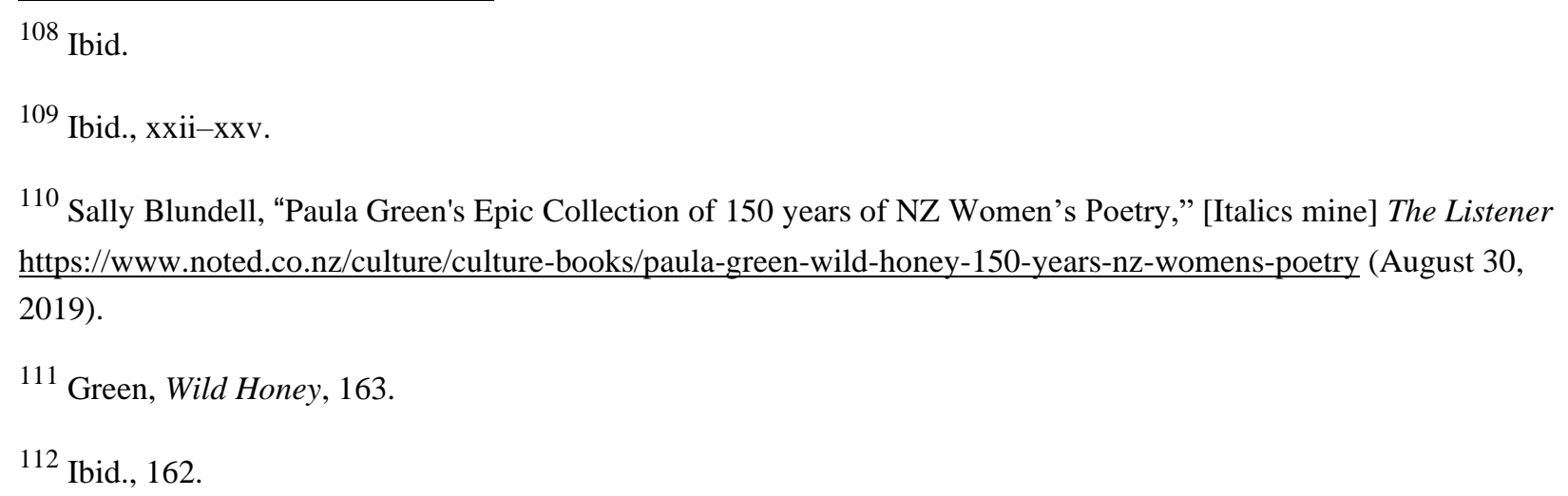


that we can now return to the domestic space and see it in a different light, because despite the more varied templates available to women, they "still produce domestic poetry". ${ }^{113}$ Therefore, to disparage the connections between women and the domestic on the grounds of banality or slightness would therefore be to "impoverish our entry into women's writing". ${ }^{114}$ Green builds on the contribution of both Ensing and Wevers, arguing that the domestic remains an important and central space in women's poetry.

The various viewpoints of Ensing, Wevers and Green are important markers for the exploration of domesticity in New Zealand women's poetry. Changes from Ensing's 1977 volume to Wevers' own 1988 anthology suggests that poets were moving away from domestic themes, towards more radical and liberated subject matter. ${ }^{115}$ Yet, Green's evaluation of the domestic in her recent anthology prompts a rethinking of the domestic theme more broadly. ${ }^{116}$ Green's continuing respect for domesticity supports it as a theme for this chapter; however, I read Wevers' identification of less "clean" themes in her 1988 anthology as opening up alternative avenues into the domestic theme, rather than negating it.

In this study I do not categorise the domestic as solely maternal or only taking place within the kitchen. Domestic poetry does not have to conform to any prescriptive ideas of domestic experience, and therefore its study requires attention to diverse frameworks and an expansion of the theme. Scholars have already engaged in such expansion. Notably, Susan Fraiman, in her work on domesticity, strongly advocates for severing it from both "the usual right-wing pieties and the usual left derision". ${ }^{117}$ Such re-evaluation of domesticity is partly my objective; however, I am studying

\footnotetext{
113 Ibid., 163.

114 Ibid., 170.

115 Wevers, "Introduction," in Yellow Pencils, xxii-xxv.

${ }^{116}$ Green, Wild Honey, 162-164.

${ }^{117}$ Fraiman, Extreme Domesticity, 3.
} 
religion through the domestic lens. Helen Vendler comes close to my own aim to expand the domestic category for a study of religion when she describes how, in literature, domesticity can easily "vibrate" between the safe and the strange, and that metaphysical and theological questions arise from within the domestication of our personal worlds. ${ }^{118}$ A broad understanding of both domesticity and religion enables an exploration of how different registers of domesticity, religion and spirituality overlap and intertwine.

Understanding the discordance surrounding the domestic enables us to better acknowledge how to readdress the theme. Religion has not been given a central place in its discussion in New Zealand literature, and certainly not in constructive or productive ways, however, Abel and Brown show that domesticity and religion are inextricably linked. Their similarly shadowed receptions are not synonymous with disappearance or unimportance in the poetry. Indeed, religion is present in the domestic throughout New Zealand women's poetry. The poems in this chapter show a religious domestic in which the domestic category is found to be more complex, variegated and expansive than is typically conveyed in scholarship. As with my trialectical treatment of religion, disrupting the domestic proves analytically productive. It demonstrates that a religious domestic may be, by turns, pleasant, threatening, protective, and provocative.

\section{Angels in the House}

Domestic poetry in New Zealand often assumes a demotic and vernacular tonality. It does not always employ explicitly or transparently religious vocabulary or imagery. I begin, therefore, by focusing on two poems which are unequivocal in their use of religious vocabulary and in their representation of domesticity. I read these poems as exhibiting a frank religious domestic poetics.

\footnotetext{
118 Helen Vendler, "Domestication, Domesticity and the Otherworldly," World Literature Today, Vol. 51, No. 1 (1977): 23.
} 
A valuable, if literal, starting point for exploring religion and domesticity is Airini Beautrais" "What is a God?" from Secret Heart. With a brevity of tone reminiscent of a listing poem, Beautrais alludes to a history of kitchen gods, or household gods, describing different modes of kitchen worship. The first line describes a god as "something small that lives in a kitchen", ${ }^{119}$ immediately bringing the domestic and the religious into conversation with one another. Throughout this poem material elements are described, beginning with the opening stanza suggesting that a god "may / involve cloth or wood or gold paper. It has sharp eyes and / watches everything." 120 The lines are sparse and brief, as Beautrais describes the many ways that "A god" is manifested within a kitchen:

A god is a candle burning in a quiet corner. Sometimes in silver, sometimes in brass. A string of beads or a careful painting. A god doesn't speak but listens, especially to whispers spoken into the palms of hands. It likes repetitive phrases. It looks after the rising of bread, the fermenting of wine, and makes sure that everyone is well satiated. Sometimes gods want food for themselves, but just to keep them warm, never to eat. The steam rises off a bowl of rice and the god looks at it. ${ }^{121}$

The language here, though understated, suggests a shadowiness that accompanies the kitchen worship: the burning of candles suggests the presence of light and shade; and the "careful" painting may be read as cautious placement of imago dei. The style of presentation contributes to the

\footnotetext{
119 Airini Beautrais, Secret Heart (Wellington: Victoria University Press, 2006), 40.

120 Ibid

${ }^{121}$ Ibid. NB: Due to this thesis' location in religious studies, throughout the thesis I have chosen to eschew some expected literary studies citation conventions. Poetry quotations will be cited by page number, rather then by line number, and footnoting is used rather than literary studies' parenthetical citation style.
} 
reading; the poem is densely formatted, with the lines packed into one another, reminiscent of a verse in a religious text. ${ }^{122}$

The specific "god" Beautrais is referencing changes frequently. It could be a Chinese Kitchen god, as suggested with "rice", or the Greek god Dionysus, through the reference to "wine". The candle and beads evoke several different religions, as such aids to worship are prevalent in many. Through this rich imagery, Beautrais invokes a long and diverse history of kitchen worship and domestic religious tasks. The practicality of this domestic worship is also emphasised, as the still-life images entail preparation: the lighting of candles, the act of prayer, and the preparing of bread, wine and rice.

The last stanza can be read as a transcendence out of the kitchen, as the poem deliberately evokes multiplicity:

A god can split into parts, sometimes thirty-three million parts. The Father Son and Holy Ghost are a Holy clover leaf. ${ }^{123}$

The splitting of the god into "thirty-three million parts" refers to the 330 million, or 33 crore, gods in Hinduism, ${ }^{124}$ while the description of the Holy clover leaf references the Irish Catholic tradition of deploying the shamrock as a metaphor for the Holy Trinity. Where the first stanza packs different ideas of kitchen worship and kitchen gods into one concentrated whole, the last stanza introduces polytheism and trinitarian thought.

\footnotetext{
${ }^{122}$ It should be noted that most of Secret Heart is written in these tightly packed lines, but in this particular poem the formatting choice lends itself to the subject matter.

${ }^{123}$ Ibid.

${ }^{124}$ David Lawrence, "Hindu Theism," The Routledge Companion to Theism, eds., Charles Taliaferro, Victoria S. Harrison and Stewart Goetz (New York: Routledge, 2013), 78-79.
} 
The kitchen setting of the poem, and the plurality of gods touched upon, pulls the reader into a dialogue with a history of domestic worship. In describing the substance of kitchen gods - their make-up of "cloth or wood or gold paper" - and the practical aids to worship - the string of beads, the rice - the poem can be read as a clear engagement with a religious trialectic; the "god" is characterised by material engagements and the domestic tasks around it have as much salience as the god itself. ${ }^{125}$

Another poem, by Cilla McQueen, remains in the kitchen but shifts from the imagery of gods to the Angel in the House. The unavoidable relevance of the image of the Angel in the House to domestic literature is worth a momentary precis. Coventry Patmore's mid-nineteenth century poem took the phrase as its title, establishing the Angel in the House as the epitome of the model Victorian woman. ${ }^{126}$ Since the $20^{\text {th }}$ century Patmore's poem and the broader connotations surrounding the Angel in the House have been criticised and satirised by feminist writers, most notably in Virginia Woolf"s 1931 speech "Professions for Women" ${ }^{127}$ Here, Woolf describes the woman writer's struggle with this image of feminine purity, and her own eventual dispatch of the "phantom" - "Killing the Angel in the House was part of the occupation of a woman writer."128 More recent usage is customarily either derogatory or as short-hand for the stock character of the Victorian, docile woman, such as David Copperfield's Agnes or The Awakening's Adèle Ratignolle. As discussed above, Riemke Ensing was keen to assure her readership in 1977 that "the New Zealand women poet is still the "Angel of the House.""129 This seemingly positive usage is

\footnotetext{
${ }^{125}$ A similarly direct description of religion and the domestic can be found in Kate Camp's poem "The gods", see Kate Camp, Beauty Sleep (Wellington: Victoria University Press, 2005), 28.

${ }^{126}$ See Coventry Patmore, The Angel in the House, together with, The Victories of Love (London: Routledge, 1905). The first, of four installments, was originally published in 1854, with the last published in 1862.

127 "Professions for Women" was originally delivered as a paper read to the Women's Service League in 1931, and was posthumously published in The Death of the Moth and Other Essays in 1942.

${ }^{128}$ Virginia Woolf, The Death of the Moth and Other Essays (New York: Harcourt Brace Jovanovich, 1974), 240.

${ }^{129}$ Ensing, Private Gardens, 12.
} 
intriguing, given Woolf's demolition of the image and phrase over fourty years earlier, and those contemporaries of Ensing, notably Elaine Showalter, who were similarly asserting Woolf's sentiments in the 1970s. ${ }^{130}$ McQueen's poem “The Angel” is enhanced by a reading that acknowledges this history of the Angel in the House.

McQueen's "The Angel” subtly plays with the image of the Angel in the House. The poem remains in the domestic space, but brings the angelic and spiritual into the kitchen, and with a feline simile, "The Angel jumped up on to the sink bench like a cat". ${ }^{131}$ This Angel in the House is described with the same calmness of tone as Beautrais' kitchen god. McQueen does little to describe the presence of this angelic being, instead asking conversationally "You know, how they fly in dreams?" The poem pulls together the quotidian and the sacred, which is further emphasised in the lines:

He stretched out his arms

\& flew diagonally upwards in slow motion.

He hovered,

sustained by a tiny shuddering

that oscillated between gravity \& lightness.

The gender pronoun of "He" further subverts the traditionally feminine archetype of the Angel in the House. The hovering between "gravity \& lightness" can be read as the amalgam of two seemingly opposing elements, such as a cat-like angel in a kitchen, or the angelic and the quotidian. Something of Luckmann's little transcendences can be read into these lines as the reverence of the

\footnotetext{
${ }^{130}$ See Elaine Showalter, "Killing the Angel in the House: The Autonomy of Women Writers", The Antioch Review, vol. 32 , no. 3 (1972): 339-353.

${ }^{131}$ Cilla McQueen, Benzina (Dunedin: John McIndoe Limited, 1988), 10.
} 
angel meets the everydayness of the kitchen sink, and as gravity meets lightness. And yet, while the religious meets the diurnal, this is an unexplained and fairly smooth contrast, and the presence of the Angel in the House is treated with an almost bathetic casualness.

These poems articulate a religious domestic. While Beautrais identifies a historical and universal relevance of a religious kitchen domesticity, McQueen softly builds spiritual transcendence into the domestic sphere in an understated manner. There is a safe strangeness in both poems, and the appeal of this domestic spirituality is foregrounded. The religious domestic in these examples suggests an understated domestic transcendence; the New Zealand tendency towards a vernacular tone, neatly exemplified in McQueen's Kiwi interrogative "You know", can make the religious themes appear less overt, and yet gods and angels are still present in the house. ${ }^{132}$

In both poems, the religious is foregrounded, and even titular. Both portray the religious entities as active or central forces within the domestic sphere. Beautrais' god "watches everything" and McQueen's angel has all the command of a family cat. The predominance of both reflects the spiritual potency of the domestic sphere, but it also resonates with the idea of the shadowiness of the domestic, in which gods and angels appear but are never fully explained. It is somewhat latent a spiritual potential as much as realised power. These poems give shape to spiritualities that articulate experiences of the domestic, turning the kitchen god and the Angel in the House into perplexing and powerful images, rather than ones of domestic subservience.

132 Ibid. 


\section{Anecdote and the Religious Domestic}

In this section I explore an anecdotal religious domesticity in which religious language is woven into the domestic realm, rather than being conspicuously apparent. Anna Smaill has identified anecdote as a mode of poetry which took hold in New Zealand, particularly since the 1990s. ${ }^{133}$ There is a broad consensus among scholars that New Zealand poetry has become characterised by its informalities and conversational tones; it has been noted for its "dirty silences", ${ }^{134}$ code-switching, an "overflow [of] talk", ${ }^{135}$ and what Bill Manhire describes as "a touch of the mongrel". ${ }^{136}$ Smaill's more specific identification of "anecdote" aids the reading of the two poems in this section.

Smaill characterises the anecdotal mode as when lyric collides with anecdote, which produces a poetry of down-to-earth tones, everyday subjects, a conversational timbre and an openness. ${ }^{137}$ Anecdote is not a gossip poem, but rather a literary illustration of conversation, sometimes meandering through different subjects with a particular focus on smaller scale narratives. ${ }^{138}$ Although "The Angel” had a colloquial diction, McQueen is writing more in the style of the lyric fragment. In contrast, anecdote often employs a modest and commonplace manner, as though overhearing a story. ${ }^{139}$ Smaill has identified anecdote as coalescing easily with domestic stories, and I read the following examples from Jenny Bornholdt and Martha Morseth as indicative of this anecdotal mode. Both poems move through familiar spaces, narrating conversations and

\footnotetext{
133 Anna Smaill, “Anecdote in Post-1990 New Zealand Poetry” in A History of New Zealand Literature, 313.

134 Bill Manhire, Doubtful Sounds: Essays and Interviews (Wellington: Victoria University Press, 2000), 9-22.

135 Andrew Johnston and Robyn Marsack, "Introduction” in Twenty Contemporary New Zealand Poets: An Anthology, ed. Johnston and Marsack (Manchester: Carcanet Press, 2009), 11.

136 Bill Manhire, "Preface," in Twenty Contemporary New Zealand Poets, 70.

${ }^{137}$ Smaill, “Anecdote in Post-1990 New Zealand Poetry”, 313.

138 Ibid.

${ }^{139}$ Ibid., 315-317.
} 
interactions, and highlighting small and obscure details. Anecdotal poetry is valuable because it gives space to the minor and renders the minor surprising and important. Employing Illich's imagery once again, anecdote embraces the shadows; it is stylistically informal and its informality allows for the poetry to be quietly punctuated with religious language. Therefore, in order to fully comprehend a religious domestic poetics in New Zealand women's poetry, anecdote is vital.

In Jenny Bornholdt’s “(Feel the Doughnut)” religion meets domesticity in both explained and confused ways. The opaque spiritual moments of transcendence, and the more obvious splicing of religious imagery, fall, as if unintentionally, into an anecdotal wave of domestic life and parental care. The passivity of the poem has a light tranquillity, but one which occasionally tingles with an otherworldly energy. "(Feel the Doughnut)" exemplifies a trialectical religion, as the quotidian, the transcendent and the scriptural blur into one another. The poem is set in the messiness of raising a child who "wants to take hold / of language, in the same way that / he tries to pick the pattern up / off the carpet". ${ }^{140}$ Mismatched clutter, both physical and abstract, illustrate the domestic chaos of the speaker's life:

There are leaves in the washing, dominoes in the garden, a dream adrift on the bathroom floor. Sometimes there's a dog. ${ }^{141}$

Bornholdt's anecdotal mode allows for moments of ephemeral transcendence to be dropped into grounded, earthy lines, such as the bathroom floor's "dream" and the fleeting dog. Later in the poem the speaker wakes to find the moon "still serene in the sky" only to have this celestial moment brought back down to earth through their child's question "Hey, what's that big / marble

\footnotetext{
140 Jenny Bornholdt, These Days (Wellington: Victoria University Press, 2000), 53.

${ }^{141}$ Ibid.
} 
up there?"142 These moments lift the poetry out of the profane sphere for just a moment and articulate a spirituality which is necessitated by, and built out of, the domesticity of the setting.

Distinctly religious imagery comes through the voice of the radio, amid the daily chores of food preparation:
Pears serious
on the table.
We eat ham sandwiches
made from leaves, there's jam
in the bed and milk
cool against your leg.
You turn on the radio and hear
It's really just a matter of getting Jesus and the disciples
across the road.
If only it was that
simple. Instead you watch
men work on it - whole days
spent in the company of concrete mixers
and bulldozers ${ }^{143}$

The link from the radio to the roadworks builds on the religious imagery, constructing extended parables into the everyday. ${ }^{144}$ The religious language and the moments of transcendence and strangeness are understated, like the ordinariness of McQueen's angel “oscillating” in the kitchen.

\footnotetext{
142 Ibid., 54.

143 Ibid., 53. The "Jesus and the disciples" lines may be referring to the encounter on the road to Emmaus, one of the early appearances of Jesus after the resurrection, see Luke 24:13-35.

${ }^{144}$ Sonja Yelich's collection Clung (Auckland: Auckland University Press, 2004) also uses the radio as a poetic technique within the domestic sphere.
} 
The last stanza describes a church sign which invites its readers to "come in, rest / and pray". ${ }^{145}$ The religious invitation is followed up with the speaker's response: “yes, yes, we say and / god bless the nesting / farm animals". ${ }^{146}$ This conversational style does not negate the previous line, but gently places the religious in a dialogue with the day-to-day, balancing it with household tones and the concept of a rural domestic. In both instances, the religion comes into the domestic sphere through external sources - the radio and the church sign. Neither is invasive, but instead suggests that such external reminders of religion are natural and normal and can fit within this domestic sphere. The allocation of what is profane and what is sacred shifts, as the moon becomes a marble and the radio is the vehicle of religious language, as the poetry ebbs and flows between domesticity and spirituality. The anecdotal mode allows that flux to be almost unnoticeable and achieves an easy relationship between the religious, the spiritual and the secular. Bornholdt's domestic chaos, spliced with moments of transcendence and religious language, has an inviting and agile charm.

Martha Morseth's poem "Communion" has some of the same anecdotal qualities as "(Feel the Doughnut)", although admittedly it is not as stylistically anecdotal by Smaill's standards. Here, anecdote relates the bleakness of an ageing and lonely domestic experience. In "Communion" the speaker describes the interior life of an elderly friend through the imagery of Christian worship. A loneliness pervades the scene, visible in the description of the "wire holder for letters, except / there are no letters" and the dialogue which reads: “'You just sit,' she says [...] She doesn't need to add, 'Just listen'." ${ }^{147}$ An eclectic assemblage of objects are described in almost painful detail:

On the walls, calendar mountain scenes, Canadian

forests, Arrowtown in autumn

\footnotetext{
145 Ibid., 55.

146 Ibid.

${ }^{147}$ Martha Morseth, Stay Inside the Lines (Wellington: Inkweed, 2002), 36.
} 
On the darker wall, the coal stove

wall, a souvenir tea towel with native birds

up and down the borders, singing to the weeks

and days. At the window sill, a plastic frog

with movable limbs, a tiny vase with an artificial

flower. ${ }^{148}$

The specificity of the poetry illustrates the small particulars which make up a home.

Making tea becomes a "liturgy of preparation" which is written with real-time specificity in run-on lines, with no full-stops, encouraging a prayer-like reading:

I know my part in the liturgy of preparation,

of the slow crisscrossing of the awkward kitchen

to fill the jug, to plug it in, to get the tea, to warm

the pot, to pour the water out, to measure the tea,

then reheat the jug, to pour the water in again, to get

the milk and sugar, the plates, the cups, the spoons,

the biscuits, all the time intoning who moved away,

which ones died of what disease and where

her sister lives and isn't it a shame she herself

has never married but has a good life all the same

and is on the list for the home where she won't

worry about roofs and gutters and hedges and lawns

and ordering in the coal. ${ }^{149}$

The word choice of "intoning" evokes the chanting of a religious text with little variation in the voice. Again, the loneliness and old-agedness visible in the first stanza reappears with descriptions

\footnotetext{
148 Ibid.

149 Ibid.
} 
of death, disease, moving away and solitariness. The sequential tasks of tea-making flatten the tone of the poem and represent a repetitive domesticity of repressed fatigue. ${ }^{150}$

The poem ends with the protagonist hoping for a place where "she can take / communion of tea and biscuits three times a day". ${ }^{151}$ The poem's intertwining of domestic rituals and religious language suggests that both have become outdated, old and passed over. The painfully meticulous detail of the tea-making process does not show the "communion" in a positive light. The word choices of "liturgy", "communion" and "intoning" imply a repetitiveness reminiscent of religious ritual, but the tone is tired as the speaker slowly criss-crosses "the awkward kitchen." 152 Morseth's poem can be placed with Abel's and Brown's analysis of the decline of domesticity.

In both Bornholdt and Morseth's poems the anecdotal mode allows the religious language and spiritual expression to weave seamlessly into the poetry. In each poem the religious allusion is justified and not unexpected. Thus, I read both poems as a continuation of a religious domestic poetics. The poems describe different places on the age spectrum, which suggests the broad variety of ways that religious articulation and spiritual experience can appear in domestic poetry. Bornholdt's "(Feel the Doughnut)" is chaotic, messy and light, and religious language breaks into this domestic sphere, illuminating and confusing the poem. In "Communion", the religious language represents the repetitive and ritualistic nature of ageing domesticity. Bornholdt's poem vibrates with moments of otherworldliness, but Morseth's is shadowy and the religious timbre throbs quietly beneath the lines.

\footnotetext{
${ }^{150}$ Anne Powell's poem “The Jug of Water" similarly combines domestic fatigue and religious imagery, see Anne Powell, Tree of a Thousand Voices (Wellington: Steele Roberts, 2010), 13.

151 Ibid.

152 Ibid.
} 


\section{Religious Domestic Shadows}

The poems in this section are somewhat of a divergence from usual stereotypes of the domestic theme in women's literature, but they are no less domestic. Ensing's suggestion that the New Zealand woman poet gravitates towards "the inoffensive, the safe, the pleasant and clean" is, I would argue, an indication of what readers and critics in 1977 expected to find in an anthology of women's poetry. I rethink the parameters of domesticity as a poetic category, and in doing so encapsulate a broader spectrum of experiences. Illich's shadows are particularly useful in reading the poetry of Meg Campbell and Tusiata Avia. Both poems are domestic, they can also be read as religious and spiritual. But in both they articulate a domesticity which tends to be relegated to the shadows.

In Campbell's collection The Way Back, an epigraph from 1 Corinthians, 14:35, immediately establishes her as a poet who brings together religion, poetry and gender: "It is a shocking thing that a woman / should address the congregation." 153 Throughout this collection, Campbell's poems relate the experiences of women in situations where their voices are silenced and their existences made small. In many of these, the domestic is the setting, as is the case in "Long Day's Journey", which narrates the fatigue of domestic life. Similarly to the previous Morseth poem, this domestic setting is predominantly tiring rather than pleasurable, but where the domestic in "Communion" was desolate, the domestic in "Long Day's Journey" is threatening.

The poem consists of four stanzas interspersed with italicised verses from Saint Ignatius of Loyola’s “A Prayer for Generosity". ${ }^{154}$ Descriptions of domestic work are followed by the religious quotes which enforce the idea of a conditioned duty:

I have tucked my needs away

\footnotetext{
${ }^{153}$ Meg Campbell, The Way Back: poems (Pukerua Bay: Te Kotare Press, 1981), 7 [Italics in original]. ${ }^{154}$ See "Ignatius Loyola”, Saint Matthew's Westminster, www.stmw.org/ignatius.html (accessed 17 August 2019)
} 
under my skirt. I am

my mother's good daughter,

will work for you devotedly,

never asking for reward.

Teach us to serve Thee

as Thou deservest... ${ }^{155}$

These first stanzas expose the subservience of the speaker's marriage - a wife working "devotedly" for her husband. As in Morseth's "Communion", the motif of tea making is representative of domestic work, but in this poem the description is far more fraught as the speaker describes the demands placed upon her:

I think you an exacting man

pressing me

in my white exhaustion

to cook, clean, brew more tea

to wear a nice face

and look to my tasks with good grace.

Teach us to toil

and not to seek for rest... ${ }^{156}$

"Good grace" has religious connotations, and the alliterative "ex" in "exacting man" and "white exhaustion" starkly emphasises both words. The next stanza reinforces the hardship of marital and domestic labour:

Under my skirt I have hidden

\footnotetext{
${ }^{155}$ Campbell, The Way Back, 27.

${ }^{156}$ Ibid.
} 
my unsuitable self.

A terrible prayer, learned

at a school for young ladies

shortcircuits my brain.

\section{Teach us to labour}

and not to ask for any reward...

"Under my skirt", from the first stanza, is repeated here, which could be read as referencing sexual frustration, or as depicting the materiality of a domestic facade. The hiding of one's "unsuitable self" speaks to the conformity which domesticity has placed upon the speaker.

The concluding stanza describes a nightly metronomic routine, where dependants are asleep, but the simmering tension of the domestic situation is greater than ever:

$$
\begin{aligned}
& \text { It is close to midnight } \\
& \text { the house is set to rights - } \\
& \text { children, dogs and cats } \\
& \text { breathe with the ticking } \\
& \text { of the clock. My clothes } \\
& \text { fall in a heap beside } \\
& \text { the bed where you lie, } \\
& \text { feigning sleep. }
\end{aligned}
$$

The poem concludes with the continued demands of domesticity. The husband has the presence of the god the speaker has been trained to "serve" and these two characters, the husband and the god of Saint Ignatius' prayer, become conflated. Religious metaphor and verse convey the threat of the domestic, as service becomes a synonym for slavery, in ways reminiscent of the "terrible prayer". In this domestic setting, religious language becomes a vehicle through which hardship is translated.

\footnotetext{
157 Ibid., 28.
} 
Saint Ignatius' prayer controls these stanzas, just as the language of liturgy mediates Morseth's “Communion". In Campbell's poem, the shadows of both domesticity and religion become threatening and abrasive. An analysis of a religious domestic poetics in Campbell allows the domestic category to expand into the realms of darker domesticities in which spiritual expression is not pleasant as it is in the poetry of Beautrais, McQueen and Bornholdt.

Campbell's poem registers the domestic as oppressive and possibly dangerous. Tusiata Avia's "This is a Photo of My House" is a detailed description of a home which is hauntingly dangerous. ${ }^{158}$ This poem comes from Avia's collection Fale Aitu: Spirit House. A poet of Samoan and English descent, Avia uses the language and imagery of spirits, aitu and atua. ${ }^{159}$ The title of this collection suggests an interconnectedness of religion, spirituality and domesticity. Several of the poems could be read as expanding the parameters of the religious domestic in New Zealand women's poetry. Here I only analyse one.

"This is a Photo of My House" reads like a tour, as, with a childlike timbre, the speaker guides the reader through the rooms. Violence seeps into the poem, and shows, rather than tells, the possible dangers that arise in each part of the house. The opening lines describe the house as having "pink bricks and a big tree". ${ }^{160}$ The driveway retains the warmth in summer and "it keeps you warm if you are wet". ${ }^{161}$ These expository descriptions are juxtaposed by the speaker's entrance into the house:

This is the screen door, swallow. Front green door, hold your chest. The carpet is dark grey and hurts your knees, it doesn't show any blood. Here are the walls, be careful of the

\footnotetext{
158 Tusiata Avia, Fale Aitu: Spirit House (Wellington: Victoria University Press, 2016), 13.

${ }^{159}$ Ibid., 78. Avia translates "aitu" as "spirits" and "atua" as "gods" in the "Notes" to the collection.

160 Ibid.

${ }^{161}$ Ibid.
} 
small girl in the corner. Here is the door into the hall, be careful of that too. ${ }^{162}$

The carpet's colour and its texture on "your knees" suggests a sinister undercurrent. The tentative repetition of "careful" sees the comfortable familiarity of domesticity stripped away, and instead this house is permeated with a sense of deep terror. The kitchen in this poem differs wildly from the kitchens of Beautrais and Morseth, but is nevertheless a seemingly safe zone in an unsafe environment:

Here is the line where the carpet stops and the kitchen starts, that is a different country - if you are in the kitchen you are safe, if you are in the lounge on your knees you are not. ${ }^{163}$

This cartographic division demarcates safe and unsafe zones. Already apparent, domestic violence is clearly articulated when the speaker leads us to the bathroom, where "the aunty punched the uncle / in the face till he bled". ${ }^{164}$ The telephone makes an appearance, and the associated elided words speak to its usual use:

Here is the lounge again, here is the phone: ringthepoliceringthepolice. Here is the couch, it is brown, watch out for the man, he is dangerous.

Throughout these lines ephemeral characters appear and reappear, similarly to McQueen's “Angel” or Beautrais' watchful "god”, but less identifiable and in shadier cadences. The "small girl in the corner" introduced early in the poem comes in and out of the lines; later the speaker describes

\footnotetext{
${ }^{162}$ Ibid.

${ }^{163}$ Ibid.

${ }^{164}$ Ibid.
} 
"There is the piano. There is the ghost." 165 Another character, "the woman", appears when the speaker returns to the kitchen:

Here is the beginning of the lino in the kitchen again, here is the woman. Watch out for the girl in the corner, she is always here. There is the woman, she just watches and then she forgets. ${ }^{166}$

These spectral characters, "the girl in the corner", the "ghost", and "the woman [who] "just watches", people the poem but make no noise. The poem culminates in three short stanzas which see the speaker transcend the confines of the house, disassembling it, and there is a possible allusion to the Gospel of Luke in the phrase "big hole in the roof": 167

I am cutting a big hole in the roof. Look down through the roof, there is the top of the man, you can't see his face, but see his arm, see it moving fast.

I am removing the outside wall of the bedroom. Look inside, there are the Spirits, that's where they live.

Stand outside in the dark and watch the rays come out through the holes - those are the people's feelings. ${ }^{168}$

The speaker assumes a god-like, bird's-eye position as they cut the hole in the roof, making the invisible visible and revealing the violence at the centre of the house. As the speaker continues to

\footnotetext{
165 Ibid.

166 Ibid.

${ }^{167}$ Luke 5:19: "But they could not find a way to take him in because of so many people. They made a hole in the roof over where Jesus stood. Then they let the bed with the sick man on it down before Jesus." [Italics mine]. New Life Version $(N L V)$.

168 Ibid.
} 
remove the bedroom wall, "the Spirits" and "the rays" are exposed, and the edificial confines of the domestic are deconstructed, suggesting a transcendent flux between the profane and the sacred.

Avia's poem expands the potential for a religious domestic reading. The poem moves between the unsafe and the uncanny. The only safety present appears to be held in the linoleum kitchen; everywhere else is "dark" and "dangerous". The shadows in this poem are both theoretical, alluding to a shadowed side of domesticity, and literal, in the description of the house. Both Campbell and Avia portray a religious domestic which broadens understandings of the domestic theme and identify it as a widely varied one, and as enmeshed with the religious. In “Long Day's Journey" the religious component is very clear, and rhetorically frames the poem and its subject matter. In "This is a Photo of My House" the spirits which live in the bedroom are a more indeterminate articulation of a spirituality. These poems show that religious and spiritual articulation can be afforded both transparently and opaquely.

\section{Conclusion}

An analysis in terms of religion enhances an understanding of the expanse of the poetic domestic, including its darker, shadowed contours. The language of religion and spirituality is used to frame experiences of domesticity and illuminates religion as a textured and multidimensional element. Religion is intricately etched into representations of domesticity, but to understand the full extent of this requires disruption.

Framing religion in conversation with the secular and the spiritual, aims to expand what is closed and oppositional. A trialectical framework and the analysis of the domestic theme are mutually productive. Disrupting the boundedness of the category of religion encourages, and even necessitates, the expansion of the domestic category. This shows us that attention to religion in New Zealand women's poetry reveals that which may not have been apparent otherwise. 
Domestic literature should not be designated as inconsequential or trivial because it takes the home as its subject. There is positivity, pleasantness and lightness in the domestic, but there is also confusion, pain and darkness. An analysis of the religious domestic has revealed these textures. A religious reading has allowed for fresh angles on a theme which is often tainted with triviality. The poems in this chapter show the domestic to be pervasive in New Zealand women's poetry, which is not in itself particularly surprising; what is important are the contrasts, complexities and fresh angles that an analysis of religion brings to the theme. Attention to religion shows that there is an abundance of domestic poetry, but it can have tones and expressions which contradict stereotypical conceptions. 


\section{CHAPTER Two}

\section{BODY AND FLESH}

In Poetics of the Flesh Mayra Rivera identifies two different corporeal poetic imaginaries the somatic and the carnal - in a selection of Christian texts. ${ }^{169}$ Rivera's somatic poetics is characterised by yearning to live in a body freed from any connotations of lust, sin, race, gender, sex or death. In a somatic poetics, the flesh is represented as inessential, and materiality, malleability and weakness are discarded. ${ }^{170}$ In contrast, a carnal poetics re-evaluates the traits of carnality, and views materiality, frailty and changeability as resources, rather than qualities to be rejected. Rivera uses this dual schema to analyse bodies and flesh in Christian texts and to theorise how these physical things carry "memories of theological passions." ${ }^{171}$ In this chapter I use Rivera's schema of the somatic and carnal, and apply it to New Zealand women's poetry. ${ }^{172}$

Bodies are recurrent in New Zealand poetry, and the New Zealand women poets of the 1970s have been described as "embracing the female body with fiercely political, at times pseudoreligious, fervour." 173 The "pseudo" prefix in this quote is intriguing, and, I believe, not always necessary. In poems by New Zealand women, the imagery of bodies and flesh is often accompanied by religious and spiritual language, an analysis of which expands our understandings. Admittedly, both words are weighted with a religious aura which can be troubling and uncomfortable, but to avoid these associations would be, in Rivera's words, "to renounce the obligations of thinking." 174

\footnotetext{
${ }^{169}$ Mayra Rivera, Poetics of the Flesh (London: Duke University Press, 2015), 153.

${ }^{170}$ Ibid., 154.

${ }^{171}$ Ibid., 1.

${ }^{172}$ I have been aided in understanding how the 'body' applies to, and functions within, New Zealand writing by Michelle Keown's Postcolonial Pacific Writing: Representations of the Body (London: Routledge, 2005).

${ }^{173}$ Harry Ricketts and Mark Williams, "From Hiruharama to Hataitai” in A History of New Zealand Literature, 230.

${ }^{174}$ Rivera, Poetics, 58.
} 
Rivera's schema of somatic and carnal poetics provides a clear framework for this analysis. In the first section I explore a somatic poetics, where body-words meet reverence and sacrality. ${ }^{175}$ In these poems, the body appears fleshless and fragmented, and the language of flora and fauna runs through them. In the second section I identify a carnal poetics, in which the poets use fleshly imagery. These poems create enfleshed images of maternal genealogies, goddesses and female deities. Here, carnality is strongly embraced.

Throughout this chapter I use both the words 'body' and 'flesh.' 'Flesh' is a perturbing word; for postmodern philosophers it has uneasy associations with sin, women and homosexuality, and a troubling religious timbre. ${ }^{176}$ In contrast, the word 'body' tidily encapsulates everything from flesh, to bone, to blood, to skin, and in doing so it denotes something complete, whole, normalised and unattainable. ${ }^{177}$ 'Body' can be seen as a reified category, whereas 'flesh' is a "slippery" term, one which "admits our exposure [and] our vulnerability". ${ }^{178}$ Flesh is ambiguous, bloody, meaty and haunting, carrying connotations of lust, sinfulness, instinct and dying. In both religion and gender theory, the feminisation of flesh and its synonymity with weakness and carnal depravity makes it a particularly provoking word. ${ }^{179}$ In the New Testament the flesh is typically contrasted with spirit, as in being led by the power of unregenerate human desire as opposed to the guidance of the Holy Spirit. The influence of Christianity in women's poetry is particularly apparent in this chapter. I address this directly.

\footnotetext{
175 Ibid., 4. Here, and throughout this chapter, I take the term "body-words" from Rivera.

176 Ibid., 1.

177 Ibid., 7.

178 Sharon V. Betcher, "Becoming Flesh of My Flesh: Feminist and Disability Theologies on the Edge of Posthumanist Discourse," Journal of Feminist Studies in Religion 26, no. 2 (2010): 107.

${ }^{179}$ Rivera, Poetics of the Flesh, 5; Helena Michie, The Flesh Made Word: Female Figures and Women's Bodies (Oxford: Oxford University Press, 1989), 4-11.
} 


\section{A "Buzz" of Body Theory}

It is an odd paradox that to engage the material flesh literature must always resort to rhetorical mediation. Historically, women's bodies within literature have been sculpted by the poetic styluses of male writers, resulting in images of the corporeal which are masculine constructions. This is deftly illustrated in Erica Jong's 1973 seminal novel Fear of Flying, as the narrative voice muses on how "throughout all of history, books were written with sperm, not menstrual blood. Until I was twenty-one, I measured my orgasms against Lady Chatterley's and wondered what was wrong with me. Did it ever occur to me that Lady Chatterley was really a man? That she was really D. H. Lawrence?"180 Such rhetorical mediation has resulted in the body occupying a fraught space in literature. The time period of my study begins in the 1970 s when the 'return to the body' was increasingly influential feminist theory, and yet this also posed a problem. To ignore corporeality and carnality would be to ignore the pressing importance of the physical, but to give it too much agency could encourage biological essentialism. Feminist theorists wanted to both take back the body and to reject the ways it had been portrayed and restrained. Key to this dilemma is the body-soul dualism.

A foundation of Western thinking is the body and the soul, two contrasting elements, which are complementary but conflictual. This dualism has overwhelmed occidental thought since at least the time of Plato (c.428-c.348). A detailed history of the body-soul dualism would be too large a task to attempt here, but a grasp of this concept is useful. While Christianity is an outgrowth from Judaism, the body-soul dualism was derived from Hellenistic admixtures of Greek philosophy and Levantine theosophy. ${ }^{181}$ In ancient Greece the soul, or psyche, was not considered an agent of morality but simply as breath necessary for life. Pythagoras turned away from the early Greek

\footnotetext{
${ }^{180}$ Erica Jong, Fear of Flying (London: Secker \& Warburg, 1974), 73.

${ }^{181}$ Roy Porter, Flesh in the Age of Reason: The Modern Foundations of Body and Soul (New York: W. W. Norton \& Company, Inc., 2003), 35.
} 
philosophical monism towards the now more recognisable dualism. The notion that humanity is made up of two distinct elements, body and soul, had major and lasting implications in subjects including philosophy, morality, science and theology. A bad-good binary permeated the body-soul dualism, and Pythagoreans followed the concept that humans were made up of the soul, which was good and divine, and the mutinous body, which had to be controlled. ${ }^{182}$ This binary became part of Christian thought and as Christianity grew, the body-soul dualism became more entrenched in society and culture. ${ }^{183}$ The alignment of women with the body and with carnality has turned the female body into feminism's albatross. The idea that biology is destiny has been strongly questioned, and the body-soul dualism has been a primary target of feminist projects, a target which aimed to destabilise the foundations of Christian doctrine. In feminist studies, the aim to liberate women from biological essentialism has been essential, and writing the bodies of women back into texts in ways which did not subordinate them has become a central focus. ${ }^{184}$

Writing in 1929, Virginia Woolf concluded A Room of One's Own by describing how the woman poet would "put on the body which she has so often laid down" and in doing so "she shall find it possible to live and write her poetry". ${ }^{185}$ A flood of body-theory began to emerge in the latter half of the 20th century, after Woolf's words had percolated for roughly 20 years, and the "laid down" body was taken up with great intent. From the 1950s onwards, an excitement about the body

\footnotetext{
${ }^{182}$ For example: 1 Corinthians 9:27: "But I discipline my body and bring it into subjection, lest, when I have preached to others, I myself should become disqualified.” New King James Version (NKJV)

183 Porter, Flesh in the Age of Reason, 39; Evidence of the body-soul dualism became recurrent in Western literature, with dialogues between the Soul and the Flesh a recurrent motif, for example, Andrew Marvell's poem "Dialogue Between the Body and Soul" (c.1650). New Zealand poet Ursula Joan Wright's poem "Body and Soul" engages in the same tradition, see Ursula Joan Wright, Over a Long Life (Christchurch: U.J. Wright, 1988), 84.

${ }^{184}$ See Judith Butler, Bodies That Matter: On the Discursive Limits of Sex (New York: Routledge, 1993); One of the most famous lines from Simone De Beauvoir's The Second Sex is "One is not born but becomes a woman" which is credited by some as one of the first explicit arguments against biological essentialism and distinguishing between sex and gender, see Simone De Beauvoir, The Second Sex, trans. Howard Madison Parshley (London: J. Cape, 1953), 267; Also see Judith Butler, “Sex and Gender in Simone De Beauvoir's Second Sex,” Yale French Studies 72 (1986): 35-49. ${ }^{185}$ Virginia Woolf, A Room of One's Own (London: Hogarth Press, 1935), 172.
} 
began to resound in multiple areas of study, causing Albert Wendt, in 1996, to comment on how 'body' had become a "theoretical buzz word". ${ }^{186}$ Some examples of this include Germaine Greer's The Female Eunuch, which uses the theme of women's bodies as an expository, with the first section titled "Body", and with sub-chapters "Gender", "Bones", "Curves", "Hair", "Sex", and "The Wicked Womb". ${ }^{187}$ Hélène Cixous' 1975 paper "The Laugh of the Medusa" developed the theory of écriture féminine (lit. “women’s writing”), arguing that women are bound by patriarchal literary norms which imprison them in a "logic of anti-love". ${ }^{188}$ Closely associating the female body with authorial power, she advises women that: "Writing is for you, you are for you; your body is yours, take it." 189

Another French philosopher, Luce Irigaray, developed the concept of parler-femme (lit. “woman speaking"), the cultivation of a language which would accurately represent women's voices and bodies. ${ }^{190}$ Irigaray condemned phallocentric literature as traditions which historically lacked respect for feminine images and genealogies and which painted the female body as highly sexualised and self-abnegating. She encouraged women to "discover their word[s]" and interweave these words with their bodies in order to make "a living and spiritual flesh". ${ }^{191}$ Donna Harraway, in her 1991 book Simians, Cyborgs and Women, requests a "feminist writing of the body". ${ }^{192}$ The poet Adrienne Rich asked women to "think through the body [...] not to transcend this body, but to

\footnotetext{
${ }^{186}$ D. Punday, Narrative Bodies: Toward a Corporeal Narratology (New York: Springer, 2003), 3; Albert Wendt, “Tatauing the Post-Colonial Body", Span 42-43 (1996): 16.

187 Greer, The Female Eunuch, 15-43.

${ }^{188}$ Hélène Cixous “The Laugh of the Medusa” trans. Keith Cohen and Paula Cohen Signs (Summer 1976): 878.

189 Ibid., 876.

${ }^{190}$ Luce Irigaray, Luce Irigaray: Key Writings (New York: Continuum, 2004), 151.

191 Ibid.

192 Donna Harraway, Simians, Cyborgs and Women: The Reinvention of Nature (London: Free Association Books, 1991), 189.
} 
reclaim it". ${ }^{193}$ Greer, Cixous, Irigaray, Harraway and Rich present just a small sample of the magnitude of the body-theory "buzz" of the later twentieth century.

This buzz was not just prevalent in gender and feminist studies; in religious studies, there was also a "turn to the body." 194 Rivera has outlined the "large and growing corpus" of literature on the body and religion that this "turn" rendered, ${ }^{195}$ but she also critiques the tendency of religious studies, as well as other scholarship, to "reify" the body and avoid flesh. ${ }^{196}$ Rivera's intent is to "turn to the body again" and in doing so "unsettle" such reifications around the body and avoidances of the flesh. Disruption and expansion are central to Rivera's work, and, similarly, I attempt to disrupt and expand understandings of the body and flesh and religion in New Zealand women's poetry.

\section{Somatic Fragments}

In Rivera's work she describes the somatic as characterised by an abandonment of "the flesh to live in the body." 197 These poetics "dream of fleshless bodies" untouched by the weight and earthliness of flesh. ${ }^{198}$ Rivera identifies these poetics in Christian texts but they can be applied more widely. In this section I explore a somatic poetics in the work of Jenny Powell-Chalmers, Jenny Bornholdt and Rachel McAlpine. All three poems focus on the body rather than the flesh - they are identifiably somatic, rather than carnal. While not obviously religious (with the possible exception

\footnotetext{
193 Adrienne Rich, Blood, Bread and Poetry: Selected Prose 1979-1985 (London: Virago, 1987), 213.

${ }^{194}$ Rivera, Poetics, 5.

195 Ibid., 5-7.

196 Ibid., 7.

${ }^{197}$ Rivera, Poetics of the Flesh, 153.

198 Ibid.
} 
of Powell-Chalmers' poem), attention to certain words and tones, and where they are placed, reveals each of these poems as addressing the body with a spiritual reverence.

Christine Battersby asserts that in art and literature women are presented with "film-like" images of themselves which are inconsistent and disparate. ${ }^{199}$ They have to "construct [themselves] out of fragments" and therefore fragments and fracture lines should be expected when we see depictions of women, by women, in art and literature. ${ }^{200}$ In the poetry in this section, there is a recurrent motif of splitting the body, which is consistent with Battersby's theory of feminine representation. ${ }^{201}$ This somatic poetics is one of pieces, rather than a whole and realised corpus. Attention to fragments highlights the somatic nature of the poetry. There is a focus on the details of body parts and bones and where these images meet reverential description there is a transcendent quality to the language which affords a spiritual reading.

Jenny Powell-Chalmers and Anna Jackson's joint collection, Locating the Madonna, is divided into five sections which illustrate the Marian image in different contexts. ${ }^{202}$ With poems titled "The Madonna of the Tooth (the annunciation)" and "Madonna of the Ankle (the fall)", the collection thoroughly engages with the intersection of the religious and the secular. Religious connotations consistently merge with the characterisation of the Madonna as an ordinary woman, one who "tramps with muddy feet" in the Ureweras. ${ }^{203}$

\footnotetext{
${ }^{199}$ Christine Battersby, Gender and Genius: Towards a Feminist Aesthetics (Indiana: Indiana University Press, 1989), 15.

200 Ibid.

${ }^{201}$ Dinah Hawken addresses fragmentation and women in her poem "The young woman, Inanna": "Her story is written in clay / and also lies in fragments." See Dinah Hawken, Ocean and Stone (Wellington: Victoria University Press, 2015), 32-37.

202 Jenny Powell-Chalmers and Anna Jackson, Locating the Madonna (Wellington: Seraph Press, 2004). This collection is written by two poets; the poetry I use here is predominantly by Jenny Powell-Chalmers.

203 Ibid., 19.
} 
In the section titled "The Embodied Madonna", the Madonna's body is split and fractured. Poems focus on specific bodily features including her skin, back and double-joints. Never is a fully "embodied" and whole image given, instead the Madonna's body has "limbs loose / as a summer sweep / of sweet vernal". ${ }^{204}$ The Madonna's legs are described as "a tangle / of matagouri, her arms / slip from their sockets / and tumble into tendrils / of fennel, flop as if / they were falling stems / of slender winged thistle". ${ }^{205}$ The alliteration of ' $\mathrm{f}$ ' and ' $\mathrm{t}$ ' encourages a legato reading, and the flopping, falling, slipping and tumbling is bound up in the imagery of plants and herbs. This imagery is connoted again in the final stanza as the Madonna is described as holding the "upright pose / of a wild opium poppy". ${ }^{206}$ The body of the Madonna comes to pieces, not forcefully, but as her limbs "slip from their sockets" the corporeal becomes a bricolage of different bodily appendages. $^{207}$

The central image is not the "Embodied Madonna" of the section-title but is instead a disembodied one, broken up and transfigured into herbs and plants. The choice of "matagouri" encourages imagery of disjoints and breakages, given this plant's thorny, tangle-branched structure. ${ }^{208}$ Reading with Luckmann's transcendences in mind, the body of the Madonna transcends somatic bounds as her limbs become the landscape. The imagery in this poem is liberating, as the Madonna sheds the weight of the body and morphs into something beyond human restrictions. But while beyond human, the representation is still physical and linkages to land relate the Madonna to an Earth Mother image.

\footnotetext{
204 Ibid., 31.

205 Ibid.

206 Ibid.

207 Ibid.

${ }^{208}$ Matagouri is a plant native to New Zealand. The term is an anglicisation of the te reo Maori word matakoura.
} 
Jenny Bornholdt's "Reading the Body" has a similar fragmentary approach, but where Powell-Chalmers' "Madonna" naturally falls apart, Bornholdt's is more a poetics of somatic dissection. The imagery is x-ray-esque, as the body is "Back lit / clipped / on the board / light goes / through you / shows you up in black and white for / what you are - a / gather of bones." ${ }^{209}$ The skeletal word choices increase the sense of fragmentation, and the body-words, or in this case bonewords, are laced with a reverential language. Words including "open palms" and "blessing" provide a prayer-like quality:

\author{
$[\ldots] \quad a$ \\ gather of bones \\ a curled frond of a spine \\ lightly embraced by \\ that scooped-out \\ smoothness of hip \\ cavity whose bones \\ like open palms \\ seem to \\ offer themselves out \\ in a kind of \\ blessing. ${ }^{210}$
}

The "curled frond of a spine" in this stanza evokes imagery of leaves or ferns, again evoking a relationship between the body and fauna.

\footnotetext{
${ }^{209}$ Jenny Bornholdt, This Big Face (Wellington: Victoria University Press, 1988), 30. ${ }^{210}$ Ibid.
} 
The reverential language continues as the speaker describes their bones as "the bones / of my beginning. / They have stayed / with me like / true friends." 211 This reverence is enhanced by reading in the Genesis connotations of the word "Beginning". ${ }^{212}$ The continuing stanzas lead the reader through sequential descriptions of "some pictures / of the body", ${ }^{213}$ as though following an exhibition of the skeleton:
See the way the
spine tails down
to a fine twitch

the way the ribs

are arms curved

in welcome

the way the hip bones

lie like an open book. ${ }^{214}$

The skeletal images in this poem are potently and surprisingly religious. The image of the hip bones as "like an open book" and the previous description of the hip cavity as "open palms [...] in a kind of blessing" both have a liturgical timbre. While more clinical than Powell-Chalmers" "Madonna", "Reading the Body" similarly elevates the somatic using spiritual language and nature imagery.

\footnotetext{
211 Ibid.

212 Genesis 1:1 "In the beginning God created the heavens and the earth." (NKJV). Selina Tusitala Marsh's "Genesis" uses the form and vocabulary of biblical verse to frame a poem about the body and illness, see Selina Tusitala Marsh, Dark Sparring (Auckland: Auckland University Press, 2013), 36-41.

${ }^{213}$ Bornholdt, This Big Face, 30.

${ }^{214}$ Ibid., 31.
} 
In Rachel McAlpine's poem "Burning the Liberty Bodice" the incendiary title suggests the casting off of the material constrictions of the body. ${ }^{215}$ The poem opens with a casual and understated "OK / take off your clothes". ${ }^{216}$ The language is informal as the addressee is asked to "stretch and see / how your body / seems just right / almost as if / it were made for you". ${ }^{217}$ As the poem continues, the language, as in the previous two poems, becomes increasingly full of nature imagery:

your nails spring like leaves

and every goose bump sprouts

your trunk bends to the wind's drunken massage

and your scalp goes sky high

tossing like tussock ${ }^{218}$

A corporeal schema is built out of fragmentation and expansion. The body grows and germinates, as words like "sprout", "Sky high" and "spring" suggest a blooming and taking up of space.

There is a genderless energy, a desexualised but not unfeminine understanding of an exploration of the corporeal. The lines of the poem draw the reader to goose bumps, nails, "trunk" and the scalp, and the nature imagery suggests that the removed clothes have unleashed an arboreal corporeality. The poem then contracts and draws attention to non-specific parts of the body, "things":

now you notice your things

softly bumping together

and how one lip lies

\footnotetext{
215 The liberty bodice was a modern form of corset intended to provide increased movability.

${ }^{216}$ Rachel McAlpine, Selected Poems (Wellington: Mallinson Rendel Publishers Ltd., 1988), 22. Poem originally published in 1979.

${ }^{217}$ McAlpine, Selected Poems, 22.

218 Ibid.
} 
delicious on the other

in a lifelong kiss

It is hard not to hear Irigaray at this point, as the image of the kissing lips premeditates her theory of bodily auto-affection in an 1980 article "When Our Lips Speak Together". ${ }^{219}$ The final stanza of the poem suggests the illicitness of nudity despite the freedom in the expansion of the corporeal:

$$
\begin{aligned}
& \text { stop } \\
& \text { this is risky } \\
& \text { better put on your } \\
& \text { clothes }^{220}
\end{aligned}
$$

Ricketts and Williams describe this poem as praising the female body with "matter-of-fact but, in a still conservative society, provocative enjoyment". ${ }^{221}$ Certainly, far more than the poems of PowellChalmers, and Bornholdt, McAlpine's poetry is in a dialogue with the politics of second-wave feminism.

All three poems have a similar approach as they fragment the body and use nature imagery. All three also have a genderless quality, despite the "Madonna" being female. Gender is never obviously indicated in the Bornholdt or McAlpine poems. The lack of gender pronouns frees the representation of the body, rather than it being inherently caught up in a sexed or sexual representation.

Throughout Powell-Chalmers and Bornholdt's poems, there are words and cues which suggest the presence of mortality. This reading is not obvious, but some words softly gesture to death and burial. In "Reading the Body" the description of the "bones of my beginnings" looks back

\footnotetext{
${ }^{219}$ Luce Irigaray, "When Our Lips Speak Together” Signs Vol. 6, No. 1, Women: Sex and Sexuality, Part 2 (1980): 6979.

${ }^{220}$ Ibid.

${ }^{221}$ Ricketts and Williams, "From Hiruharama to Hataitai", 230.
} 
with the past-tense, and the description of "smooth bones" has an elegiac quality. In the "Disjointed Madonna" the final image of the "upright wild opium poppy" evokes the association of poppies with sleep, silence and death. In contrast, in McAlpine's "Burning the Liberty Bodice", there is an increased sense of vivification as the removal of clothes allows the body to expand and grow.

The fragments and fractures in this poetry are consistent with Battersby's film-like images, as the various bodies are described with Picasso-esque distortion. Rather than representing whole bodies, these poems show the body broken up, augmented and (in the case of Bornholdt) translucent. The representation is light, loose and oddly fleshless. In each poem, use of nature imagery takes the somatic beyond the human, locating it as part of the natural world. The Madonna's limbs which "tumble into tendrils / of fennel", the "frond" of the spine in Bornholdt, and the nails like "leaves" in McAlpine show a poetics in which writing the body means going beyond it. This is not so much a return to the corporeal as a transcendence out of it. The nature imagery allows the body in each poem to become part of an earthly make-up, as the "limbs", "bones" and "things" are expanded into an organic schema. These poems are consonant with Rivera's description of a somatic poetics as a dream of the "fleshless body." The poems do not reject corporeality, but the body is fragmented, spiritualised and subsumed into an imagery of plants and herbs. Reading these poems through Rivera's schema illuminates where body-words and spiritual language intersect in surprising ways.

\section{Carnal Strands}

This second section explores Rivera's carnal poetics, embracing carnality and moving toward a fleshly the $a \operatorname{logy}$, in which the female body is deified. These poems engage with traditional religions more frequently than the somatic poems and meditate on the body-soul dualism to a greater degree. 
Rosi Braidotti, in her book on women, bodies and representation, asserts that the subject of women's bodies is not simple or easily managed. The "implications of the phallogocentric institutionalisation of sexuality" are inscribed onto bodies: they are complex because they are "enfleshed". ${ }^{222}$ Braidotti complicates liberatory body-theory, arguing that feminists "cannot hope $[\ldots]$ merely to cast off their sexed identity like an old garment $[\ldots]$ imaginary identifications or ideological beliefs are tattooed on bodies". ${ }^{223}$ A casting off of the "sexed identity" can be read into the somatic poetics of the previous section, in which the body is largely genderless and fluid. However, in this section, the poets acknowledge the garments of enfleshed ideologies; these are not so much "cast off" as rethought, reworked, and even reclaimed in some instances. In the following examples, the poems do acknowledge the enfleshment of phallogocentric institutionalisation and religious ideologies, and the effects of these on representations of the body.

I begin this section by analysing the reference to corporeal genealogies in the poetry of Tayi Tibble (Te Whānau-ā-Apanui/Ngāti Porou) and McAlpine. In the poetry of McAlpine, Heather McPherson and Hadassah Grace, the "tattoos" of Christianity and phallogocentric ideologies are acknowledged. McAlpine and McPherson display a "thinking through the body" but also a refashioning of theology. Both their poems construct a female deity. These female deities are, I argue, examples of an enfleshed the alogical approach; a carnal female deification in which religious references meet body imagery. ${ }^{224}$ I then contrast the enfleshed thealogies of McAlpine and McPherson with Grace's poem "Ruin”. Grace, too, acknowledges enfleshed ideologies, but rather

${ }^{222}$ Rosi Braidotti, Nomadic Subjects: Embodiment and Sexual Difference in Contemporary Feminist Theory 2 nd ed. (New York: Columbia University Press, 2011), 103.

223 Ibid.

${ }^{224}$ For more on Thealogy, see Naomi R. Goldenberg, Changing of the Gods: Feminism and the End of Traditional Religions (Boston: Beacon Press, 1979); Melissa Raphael, “Thealogy” Encyclopedia of Religion Vol. 13. $2^{\text {nd }}$ ed. ed. Lindsay Jones (2005); Carol P. Christ, “The Last Dualism: Life and Death in Goddess Feminist Thealogy” Journal of Feminist Studies in Religion Vol. 27, No. 1 (2011): 129-145. 
than refashioning or reimagining a female deity, her work absorbs these into a carnal poetics of anger and retaliation.

Naomi Goldenberg in her "return of the Goddess" theory suggests that one element of second-wave feminism was turning from theology to 'thealogy' which involved "looking to the past" for images of female power and rediscovering a "feminist pre-history". 225 The following poetry by Tibble and McAlpine refers back to corporeal genealogies, in which lineages of women are recognised and expressed through body-imagery. Tibble's poem "LBD" from her collection Poūkahangatus illustrates this. Religious and bodily metaphors come together to illustrate the image of women's voices inside the speaker's body. The initial simile of "walking on water" immediately creates a biblical resonance:

moving in the club like I'm walking on water / no miracle though / mouth red like a fire engine / hair falling like debris / I get up / on the sound of women wailing / now they wail for me / I carry them inside me / bones vibrating like a ringtone ${ }^{226}$

Similarly, McAlpine's poem "Sheila's Graveyard” emphasises a collective female lineage. The body becomes a physical carrier of a matrilineal ancestry and a burial place through which the speaker can refer back to her maternal ancestors. The imagery of entombment combines religious and corporeal metaphors:

my ground is sour and sacred with the bones of all my mothers buried in me is one who worked at tubs and maths and hymnbooks

$$
[\ldots]
$$

\footnotetext{
225 Naomi R. Goldenberg, Resurrecting the Body: Feminism, Religion and Psychoanalysis (New York: Crossroad, 1993), 193-195.

226 Tayi Tibble, Poūkahangatus (Wellington: Victoria University Press, 2018), 39.
} 
buried in me is one who

bewildered with her wit<smiles>C[AlH]</smiles>

buried in me is one who stormed

the city council in a first front row attack

$[\ldots]^{227}$

In the line "Sour and sacred / with the bones of all my mothers", McAlpine pulls on a feminine matrilineal ancestry. The speaker's body becomes itself "haunted holy ground", but as well as a "graveyard" the speaker is a reincarnation of the "four women". Only one is external: the one who is "married and saying yes / on the telephone [...] the others are making war / trapped in me their bones / do battle quietly quietly / they meet like swords in clay." 228 In turning "Sheila's" body into a metaphorical graveyard, McAlpine brings together sacrality and corporeality within a skeletal framework. ${ }^{229}$

Tibble and McAlpine's imagery of women and bones speaks to the recognition of a lost history of women, as well as to a spiritual connection to a matrilineal past through the body. These poems demonstrate the difference between the somatic and carnal strands in my reading. While the plurality of "voices" (in Tibble) and "bones" (in both Tibble and McAlpine) suggest multiplicity, the voices are within the body, instead of expanding out of it. Where the previous section

\footnotetext{
${ }^{227}$ McAlpine, Stay at the Dinner Party (Dunedin: Caveman Press, 1977), 8.

228 Ibid., 8-9.

${ }^{229}$ It should be noted that lines in this poem can also be read in terms of domesticity and the shadow spirituality of the previous chapter. Recognition of the bodies of a maternal history in turn recognises the domestic circumstances of such women. Janet Charman's poem "the new house" has a similarly maternal, bodily imagery, see Janet Charman, Snowing Down South (Auckland: Auckland University Press, 2002), 72.
} 
exemplified transcendences out of the body through a focus on the somatic, Tibble and McAlpine's poems are firmly in the flesh; literally incarnate.

McAlpine's "Sheila" poems are part of her collection Stay at the Dinner Party, which engages with religion, women and carnality in an extended conversation on how to understand and live with these three elements in agreement rather than in conflict. Biographical details can indelibly mark literature and here McAlpine's poetry reflects her biography. McAlpine's father was an Anglican vicar; Christian imagery and a conflicted relationship with the church leave fingerprints all over her work. ${ }^{230}$ In her sequence "A Chat with God the Mother" the speaker divulges why she "left the church", unfolding expressions of frustration at the gendered, patriarchal nature of traditional Christianity and the practice of "praying to men for men". ${ }^{231}$ The speaker lists the ways this could be solved: she could "alternate pronouns privately", she understands that "man is metaphor for women", but the poem reaches the conclusion that "things are right for me / when flesh and spirit agree / I do not feel included". ${ }^{232}$ The pursuit of the agreement of flesh and spirit dominates the rest of the sequence, and engages with the body-soul dualism. In doing so, McAlpine creates a maternal deity, "God the Mother". It is through "God the Mother" that the poetry conceives a different understanding of religion, one which repeatedly turns to the flesh.

In two poems, "Skins" and "God the Mother Answers Briefly", the body and the soul are brought together. "God the Mother" is not distanced from the carnal but inextricably linked to it, and the agreement of flesh and spirit begins to be imagined as the poems redress the idea of the creation. "Skins" shows "God the Father" clothing men in more skins than women "to protect them

\footnotetext{
${ }^{230}$ New Zealand Book Council, “McAlpine, Rachel”, http://www.bookcouncil.org.nz/writer/mcalpine-rachel/ (accessed August 17, 2019).

${ }^{231}$ McAlpine, Dinner Party, 20.

232 Ibid., 25; Kate Camp's collection, The Mirror of Simple Annihilated Souls (Wellington: Victoria University Press, 2010), has a similar, if less positive, sequence on the difficulties of religious belief. Also see Amy Brown's The Odour of Sanctity (Wellington: Victoria University Press, 2013), a long-form exercise on sanctification.
} 
from the pain" and adding "scar tissue / thick and safe". ${ }^{233}$ In contrast, "God the Mother" gives women "seven skins / [she] knew that was enough". ${ }^{234}$ The thinner layers of epidermis mean that women can "still feel the prickle / of the stars". ${ }^{235}$ In "God the Mother Answers Briefly" this celestial and corporeal imagery continues as the deity describes how she teaches her "daughters" the art of "unravelling the soul / from the limbs the head the gut" and allowing it to roll "out of the mouth / and spilling into the night". ${ }^{236}$ Fluent in Christian understandings of body and soul, McAlpine re-stitches the body-soul dualism into her imagined thealogy, writing it to the advantage of women; they are able to hold the ends of the soul "between the teeth / while the soul rides to the moon". ${ }^{237}$ The daughters "wind in [the soul] inhale it whole / and the skein will spread into the lungs / the veins the finger tips". 238

"God the Mother Answers Briefly" concludes with the capitalised lines:

TYRANNOSAURA REGINA

HAS BLUNDERED INTO THE LIGHT

I DO NOT RECOGNISE HER

I DID NOT GIVE BIRTH TO HER

I MERELY ROLLED AWAY THE STONE ${ }^{239}$

\footnotetext{
233 Ibid., 35.

234 Ibid.

235 Ibid.

236 Ibid., 36.

237 Ibid.

238 Ibid.

239 Ibid.
} 
"Regina Caeli" (“Queen of Heaven”) is a Catholic title for the Virgin Mary which McAlpine playfully contrasts with the feminine Tyrannosaura, evoking the prehistoric origins of "God the Mother". Read alongside the biblical reference to the Gospel of Luke, ${ }^{240}$ this may imply a female reimagining of anastasis. The character of "God the Mother" fulfils the speaker's wish to have "flesh and spirit agree". ${ }^{241}$

In McAlpine's work the desire for the unity of flesh and spirit augments the parameters of Christianity. These augmentations result in metaphors and imagery grounded in the rhetoric of Christianity but claiming bodily agency and moving outside the realm of the known. I read McAlpine's "God the Mother" as an enfleshed thealogy, an image of a female deity which relies on carnal and mental cohesion. Although McAlpine's tone in the poems is reformative, rather than negative, there is still frustration at the need to reimagine a positive model of femininity given the insufficiencies of the existing Christian god.

There are similarities between McAlpine's “God the Mother” sequence and Heather McPherson's poem “Theology and a Patchwork Absolute.” Like McAlpine, biography is of value in reading McPherson as she was actively involved with the second-wave feminist movement in New Zealand and one of the founding members of the publisher Spiral. ${ }^{242}$ In "Theology and a Patchwork Absolute" McPherson constructs a feminine deity which discloses the tension between theology and feminism, invoking references to religious thought on the female body.

McPherson's is a carnal poetics of redesign. Like McAlpine, she does not cast-off Christian traditions completely, but instead actively engages with them in order to "piece out a goddess ancestry from digs / and neglected pottery". ${ }^{243}$ "Theology and a Patchwork Absolute" is in dialogue

\footnotetext{
${ }^{240}$ Luke 24: 2 "But they found the stone rolled away from the tomb." (NKJV).

${ }^{241}$ Ibid.

${ }^{242}$ See Spiral, https://nzhistory.govt.nz/women-together/spiral

${ }^{243}$ Heather McPherson, A Figurehead: a face (Wellington: Spiral, 1982), 30.
} 
with the old masters, the Bible, goddess theology, and with classical research. With the poetic voice self-reflexively engaged in the writing process, the first lines describe how "time and again I tried to write a goddess song. / Now that I have fleshed the lyric tongue a poem / stirs." ${ }^{244}$ With a "fleshed [...] lyric tongue" McPherson writes her "goddess song" beginning with the Sapphic imagery of "two women / naked on a bed. / Such proximity is heretical and a sin." 245 The aim of this goddess song is to ignore the voices of "theologians and borough councillors", whose voices "shake the boardroom", and instead to "make a goddess, ours". ${ }^{246}$ This is accomplished using the imagery of patchwork, quilting and sewing, through which McPherson addresses theology, women and the body, poetically building a new goddess whose skin is not unclean but "moon washed". ${ }^{247}$

McPherson explores how religion has affected the representation of the body and then describes the possibilities of overthrowing such representation. She argues against the need for theologians to absolve, instead suggesting that women "strip absolution" and become their own "theologians and counsellors", ${ }^{248}$ The impurity of women's bodies is addressed in biblical terms: "if sometimes / we hear Unclean Unclean we ascribe it to the / mythical leper, mournful behind his bell". ${ }^{249}$ This nod to Leviticus suggests the theological weight of impurity placed on the female

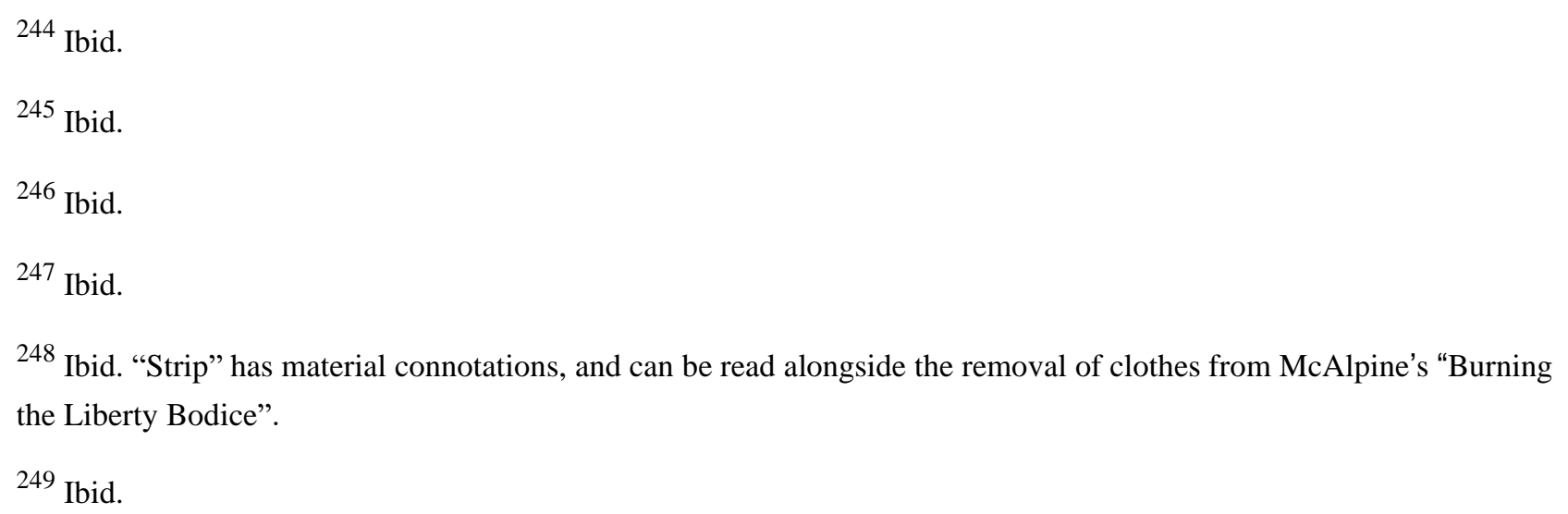


body. ${ }^{250}$ Through her "patchwork" goddess McPherson aims to "heal the biblical landscape" and rejuvenate the rhetorical mediation of female carnality. ${ }^{251}$

These examples from McAlpine and McPherson create new feminist thealogies which embrace flesh rather than transcend it. McAlpine's "When flesh and spirit agree" and McPherson's "fleshed [...] lyric tongue" exemplify an attention to the carnal. The engagement with traditional religions does not reject religion entirely but instead reconfigures paradigms of frustration and constriction. In both poems the return to the flesh leads to the creation of a maternal deity and the carnal poetics can be read as positive and revitalising. Consistent with Rivera's aim to unsettle the reifications of body and flesh, carnal poetics in New Zealand women's poetry do not offer untroubled celebrations of the female for. Instead there is a complexity of engagement with female corporeality and a struggle to forge a feminine poetic voice.

The carnal poetics identified in the poetry of Tibble, McAlpine and McPherson markedly contrast with those of Hadassah Grace. Reading Grace's poetry adjusts the perimeters of what a carnal poetics in New Zealand women's poetry looks like, and contributes to a broader understanding of body and flesh. Again, Grace's biography is relevant. Her 2019 collection How To Take Off Your Clothes ${ }^{252}$ is laced with religious references and Christian imagery. Raised by “Christian celebrities," and Jewish by birth but Christian by upbringing, a fractious engagement with religion is reflected in her work. ${ }^{253}$

Grace's "Ruin" articulates an anger using the imagery of ruined women directed at a homogeneous Christian patriarchy. "Ruin" could be read as a feminist call to arms or manifesto. I

\footnotetext{
${ }^{250}$ Leviticus 13: 45 "Anyone with such a defiling disease must wear torn clothes, let their hair be unkempt, cover the lower part of their face and cry out, 'Unclean! Unclean!'” (NIV)

${ }^{251}$ McPherson, A Figurehead, 30.

252 The title of which references Bill Manhire's 1977 collection How to Take Off Your Clothes at the Picnic.

${ }^{253}$ Hadassah Grace, How To Take Off Your Clothes (Auckland: Dead Bird Books, 2019), “Afterword”.
} 
am reading it here as an example of carnal poetics, and an enfleshed thealogy. Although a singular goddess or "god the mother" never emerges from "Ruin", throughout the poem Grace assembles a body of "ruined" women who "are not content to be [...] muses anymore". ${ }^{254}$ Fusing religious references and the bodily imagery are 'everyday' motifs, such as the description of "basic bitches on our phones in line at Starbucks" or the reference to contraception as the "restraint $[\ldots]$ we keep in the top drawer of / our bedside tables". ${ }^{255}$ Her use of the plural "we" is stark. In the poems used thus far the speaker has a singular voice, here the voice is a multiple "us" and "we":

You will know us by the lines

under our eyes and across the tops of our thighs

by the smoke stains in our voices and the whiskey words we whisper under our breath. ${ }^{256}$

The physicality in the stanza above is continued throughout the poem, and a brutal anger resonates through the polyphonic voice. An allusion to corporeal genealogies, as in Tibble and McAlpine, can be seen in Grace's reference to witch burnings:

we've always been here

the witches you burned because you knew we were magic swapping our vacuum cleaners for broomsticks and cackling about castration under the light of the full moon 257

"Witches" references back to a maternal lineage, like that of Goldenberg's return of the goddess. As it progresses, the voice takes on the imagery of impure flesh, and clearly articulates phallogocentric renderings of the female body, using these images in order to refute them. Female carnal impurity,

\footnotetext{
${ }^{254}$ Ibid., 11.

255 Ibid.

${ }^{256}$ Ibid., 10. [Italics Mine]

${ }^{257}$ Ibid.
} 
and fear of the female body and castration have been historically portrayed in folklore through the image of the vagina dentata, "the toothed vagina." 258 Here, Grace uses this motif:

our pussies have always had teeth

and we are finally ready to bite the hands that have kept us hungry

Jesus was wrong, when he went preaching on the mount we are \#blessed but we've never been meek

and we will wrestle the earth from those set to inherit it

The allusions to both the vagina dentata and the Gospel of Matthew bring together religion and the masculine representation of women's bodies. ${ }^{259}$ Similarly, Grace combines the imagery of menstruation and the 'writing in the sand' text, from John 7:53-8:11:260

we are the names they give to hurricanes and stormy oceans

you can scratch your excuses and your executive orders into the sand

but we are the monthly tide that will wash them away ${ }^{261}$

The Gospel narrative these lines allude to concerns the story of Jesus and a woman accused of adultery. When asked to pass judgment on her, Jesus scratches his response in the sand, but no one sees what he writes. This is often considered to be a lesson in grace and leniency, however, Jesus'

\footnotetext{
258 The vagina dentata has been used elsewhere in the poetry of New Zealand women. For further examples in poetry see Keri Hulme's “Deity Considered as Mother Death” in Strands (Auckland: Auckland University Press, 1992), 4445; Cilla McQueen's “The Fairies Rattle Their spoons” in Fire-Penny (Dunedin: University of Otago Press, 2005 ), 25. For evidence of the vagina dentata discussed in New Zealand scholarship see Simon Perris "What does Hine-nui-te-pō look like? A case study of oral tradition, myth and literature in Aotearoa New Zealand" Journal of the Polynesian Society Vol.127(4) (2018): 365-388.

${ }^{259}$ Matthew 5: 5 "Blessed are the meek, For they shall inherit the earth." (NKJV).

260 John 8: 6: "This they said, tempting him, that they might have to accuse him. But Jesus stooped down, and with his finger wrote on the ground, as though he heard them not." (KJV)

261 Grace, How to Take Off Your Clothes, 11.
} 
command for the woman accused of adultery to "sin no more" is a remaining tension. His refusal to condemn or to punish the woman is not the equivalent of no judgment, and tacit moral demands remain. It is this moral critique that Grace responds to in the lines above. Anything Jesus may have scratched into the sand she rejects using the image of menstrual blood.

As the poem reaches a crescendo, Grace evokes the image of the succubus, a female demon, "who will suck you dry / and you are right to be scared of us / because hell hath no fury like a woman scorned / hell hath no fury like a woman fully formed / hell hath no fury like a woman."262 The repetition of "fury" also brings in the image of the Furies of Greek religion, who "take vengeance on men, whosoever hath sworn a false oath." 263 Far from casting off the enfleshed body, she embraces it, engaging with accusations of impurity, denials of sexuality and negations of the flesh. Grace uses these male ideologies and gendered representations in the form of the succubae and the furies, to convey an anger to these representations of the body, which contrast with the empowerment of the previous carnal poetry. Where the speaker in McPherson's "Patchwork" poem aims to "heal the biblical landscape", the speaker in "Ruin" uses misogynistic imagery for a vehement attack. The last stanza aligns with the Christian calendar, despite the many references which fit outside of Christianity:

And you? you had your chance 2000 years of chances now we are everything you've always wanted everything you've always feared and we will ruin everything ${ }^{264}$

\footnotetext{
${ }^{262}$ Ibid; This line also references William Congreve's 1697 play The Mourning Bride (Act III Scene 2): "Heav'n has no Rage, like Love to Hatred turn'd, / Nor Hell a Fury, like a Woman scorn'd." See William Congreve, The Mourning Bride (London: Jacob Tonson, 1679).

${ }^{263}$ Homer, Iliad, 19. 259-260.

${ }^{264}$ Grace, How to Take Off, 11.
} 
Like Tibble, McAlpine and McPherson, the carnal strand in Grace's work has strong ties to traditional religion and Christianity, with that imagery working with the imagery of the body and flesh to create a carnal poetics. ${ }^{265}$

In the carnal poetics I have identified in this section, each poem illustrates a claiming of the flesh or an acceptance of it, whether that be in the acknowledgement of a feminine bodily lineage or in the construction of corporeal, enfleshed goddess images. Grace, however, though she claims the flesh, does not reshape it. The speaker in "Ruin" uses a litany of carnal images which are not reimagined, or refashioned, but instead evoke a history of misogyny. To return to Braidotti and her assertion that women "cannot hope [...] merely to cast off their sexed identity like an old garment [...] imaginary identifications or ideological beliefs are tattooed on bodies" 266 - Grace's poem agrees with, and advances, Braidotti's argument. Grace draws attention to the "identifications" and “ideological beliefs" tattooed on women's bodies and uses these in concert with tones of anger and revenge which dominate the poem. ${ }^{267}$

\section{Conclusion}

The importance of the body and flesh thematic is clear when we observe the abundance of body-theory from the 1970s onwards. Such theory has aimed for liberation and upwards progress of women. This drove second-wave feminism, women's liberation and the reclamation of the female body in literature. This upwards progress is sometimes taken for granted.

\footnotetext{
265 Grace's “Ruin" is tonally similar to Tusiata Avia's poem "Apology”, which combines a number of religious and confronting images with the language of the body, see Avia, Fale Aitu, 58-59.

266 Braidotti, Nomadic Subjects, 103.

267 Ibid.
} 
Studying religion in terms of body and flesh reveals a range of themes that move beyond familiar tropes of celebration and reclamation. In the carnal poetics of McPherson and McAlpine, there is a timbre of hope which pushes the poetry towards the lightness of epiphany, but this is grounded in the need to refashion religion into a maternal and gynocentric image. In contrast, Grace's poem "Ruin" acknowledges a sharp glass ceiling. Instead of a teleology of liberation, her highly allusive poem hints at a reality where the project of women's rights has stalled: she suggests a regressing narrative of decline and failure. She does not build a new poetic thealogy, but instead returns to classical and Christian images.

Reading religion in body and flesh poetry, using Rivera's schema, affects the interpretation of the poems and, more importantly, shows that religion substantially contributes to this poetry. It is used to express the value of the body, and the poets use the imagery of body and flesh to interrogate and remould religion. Religion offers expansive possibilities, which are contrary to expectations, for reading poetry of the body and flesh. It supplies vocabulary, images and textures that broaden the horizon of body exploration in poetry. A capaciousness for further study is revealed when we understand that the religious connotations of body and flesh have been, and are being, interrogated by New Zealand women poets. Bringing a religious reading to the body and flesh theme broadens registers which may have been constrained within discourses of progress, reclamation and liberation. 


\section{CHAPTER THREE}

\section{WHENUA/LAND}

In a country "not noted for religious enthusiasm" 268 it is somewhat unexpected to find a litany of New Zealand voices suggesting that both Māori and Pākehā have beliefs and traditions spiritually connecting them to land. These bicultural understandings of land, combined with New Zealand's cartographical peripherality, mean that conversations emerge about the materiality on which New Zealanders stand. These are reflected in the work of New Zealand writers. The theme of land is a ubiquitous one in New Zealand literature, including its poetry. Poets are conscious of writing "at the edge of the universe", ${ }^{269}$ and backdrops such as the bush or beach, or themes of wildlife, tramping or other outdoor activities, frequently appear in New Zealand poetry. This is unsurprisingly recurrent given New Zealand's attention to its land. What is surprising is that New Zealanders seem prepared to accept, and even claim, a land spirituality.

Connections between land and spirituality have been evident in New Zealand for quite some time. In 1988, John Bluck suggested that the "basic discipline of Kiwi spirituality" was "learning to listen to the silence of the bush". ${ }^{270}$ In 2004, Paul Morris, describing New Zealand's spiritual identity, located New Zealand's land as "the ground of our individual and collective life, it gives us our being and connects us to each other and our future". ${ }^{271}$ In 2005, poet James Brown declared that "it is not unusual, even in our secular age, to feel [when looking at the New Zealand landscape] we

\footnotetext{
${ }^{268}$ Mark Williams, “'When You're Dead You Go on Television’: Sex, Death and Household Objects in Some New Zealand Poetry” Sport 42 (2014): 152.

269 Taken from Bill Manhire’s “Milky Way Bar” in Milky Way Bar (Wellington: Victoria University Press, 1991 ), 19.

270 John Bluck, Long, White and Cloudy: In Search of a Kiwi Spirituality (Christchurch: Hazard Press, 1998$), 50$.

${ }^{271}$ Paul Morris, "Who Are We? New Zealand Identity and Spirituality," in New Zealand Identities: Departures and Destinations, ed. James Liu, et al. (Wellington: Victoria University Press, 2005), 252. Also see Paul Morris, "Spirituality Abroad: Reflections on New Zealand Spirituality and Identity," in Spirit Abroad: A Second Selection of New Zealand Spiritual Verse, eds. Paul Morris, Harry Ricketts, and Mike Grimshaw (Auckland: Godwit, 2004$), 227$.
} 
are not just viewing the work of powerful natural forces but also somehow the mark of a deity."272 In 2007 , North \& South magazine asserted that New Zealand's continuing interest in spirituality and religion was down to a "renewed sense of eco-spirituality, bound up with our unique Māori-Pākehā heritage and shared love of the land". ${ }^{273}$ The New Zealand Listener in 2010 reported that New Zealanders have a "relationship with the land...spiritual, even soulful". ${ }^{274}$

These quotes are evidence of a spiritual engagement by New Zealanders with the land, demonstrating that, in this chapter, I am not approaching a tabula rasa. However, they ring with a straightforward and almost casual simplicity. And yet, the poetry analysed in this chapter does not present as a straightforward engagement with land, rather it shows an analytically provoking imbrication of Māori and Christian mythologies, imagery and vocabularies which owes much to New Zealand's biculturalism and the separate and shared understandings of land which emanate from that. While the quotes above show an acknowledged land spirituality which deviates from broader cultural trends towards the marginalisation and neglect of religion, this is primarily conceived as decidedly 'spiritual', rather than 'religious'. A trialectical approach, with flexibility around the categories of spiritual and religion, provides space to acknowledge and explore this dynamic.

Land can be approached in many different ways, as the subject is not thin on the ground in New Zealand scholarship. In this chapter, land is recognised as being a bicultural and gendered thematic in some New Zealand women's poetry. With an attention to religious and spiritual elements at the forefront of my reading and analysis, I identify a landed religio-spiritual poetics. In the first two sections I explore how Māori and Christian understandings of land are presented in the

\footnotetext{
272 James Brown, "Introduction" in The Nature of Things: Poems from the New Zealand Landscape ed. James Brown, photography by Craig Potton (Nelson: Craig Potton Publishing, 2005), 12.

273 Caroline Courtney, “Religion: Who Needs It?” North and South April (2007): 253.

274 Jane Clifton, “Choice, Bro”, New Zealand Listener July (2010): 14-16.
} 
work of New Zealand women poets. The Christian-informed understandings of land surface through garden themes and Edenic motifs. In conversation with studies by Peter Whiteford and Jake Arthur, I read garden poetry in New Zealand as part of a specific cultural literary trend established by the New Zealand poet Ursula Bethell in the 1930s. I call upon this when examining the work of Hannah Mettner, Jenny Bornholdt and Sue Wootton. The Māori understanding of land presented in the poetry examples relies on origin and afterlife mythologies. With Vandana Shiva's "mater vs. matter" theory in mind, I explore poems by Roma Potiki, Keri Hulme and Bernadette Hall, in which mythological approaches to land present it as feminine and maternal. In the third section, I take these first two understandings and discuss how a biculturalism allows poets to connect to land through birth and death as shared experiences across cultures in and on this land. I set out a range of examples from the poetry of Anne Kennedy, Anahera Gildea and Tayi Tibble and, once again, Bernadette Hall which show a bicultural imbrication where religious and mythological understandings of land coalesce in response to birth and death.

It is important to have some understanding of the complexities of land and biculturalism in New Zealand when analysing and discussing these poems. The 1970s heralded a critical point, beginning a new era of Māori activism. The Māori Land March of 1975, led by Whina Cooper, arrived in Wellington in October at the same time as the Treaty of Waitangi Act was passing into law. That Act established the Waitangi Tribunal and marked the first time the Treaty had been recognised in New Zealand law. The concepts of Māori sovereignty (tino rangatiratanga) and biculturalism were advanced and hotly debated at this time. These developments became a primary site of literary engagement, led by Māori writers and poets such as Hone Tuwhare, Witi Ihimaera, Patricia Grace and Keri Hulme. Cultural and literary conversations and advancements at this time are described as the Māori Renaissance, a movement which grew along with calls for political 
sovereignty and the recognition of Māori culture. ${ }^{275}$ The Māori Renaissance produced a body of literary work which provided an expanded space for Māori traditional techniques, themes and characters within New Zealand literature. European-derived literary, cultural and artistic practices evolved in response. Techniques such as the linear Western narrative were replaced in Māori literature by circular literary structures, which are more consistent with an oral storytelling tradition. A product of the Māori renaissance was that Pākehā literature also began to absorb these techniques. $^{276}$

The title of this chapter, Whenua/Land, exemplifies the complications of a bicultural literature. "Whenua" can be translated as "land"277 but it can also be translated as "country", "territory", ${ }^{278}$ or "placenta". ${ }^{279}$ These polyvalent definitions demonstrate some of the tensions between Māori and Pākehā concepts of land, which make this subject culturally and linguistically complex. In particular, "whenua" translated as "placenta" indicates a relationship between the land, body and creation which the word "land" in English does not have. Some of the poetry in this chapter clearly revels in these proliferating meanings and tends to move beyond narrow and finite definitions. Like much of the language used in the poetry, examples referenced in this thesis, and poetry more broadly, there is rarely a definitive clarity.

\footnotetext{
${ }^{275}$ I use 'Māori Renaissance' to refer to the period from the 1970s, as outlined by Melissa Kennedy in her work on "The Māori Renaissance from 1972" in A History of New Zealand Literature, ed Mark Williams. I use the term with the awareness that it is also uses 'Māori Renaissance' to refer to the first half of the 20th century and the new appreciation and visibility of Māori arts, culture and notable figures which emerged at that time. For evidence of the latter usage see Atholl Anderson, Judith Binney and Aroha Harris, Tangata Whenua: A History (Wellington: Bridget Williams Books, 2015).

276 Mark Williams, "Leaving the Straight Path: Cultural Time Travel in the Seventies" in JNZL, No. 4/5 (2006): 85; Michael King, Whina: A Biography of Whina Cooper (Auckland: Hodder and Stoughton, 1983), 206.

277 “Whenua” def. 1. Māori Dictionary. https://Māoridictionary.co.nz/

278 Ibid., definitions 2, 3, 4 .

279 Ibid., def. 5.
} 
The amalgamation of Māori and Pākehā mythologies, vocabularies and imageries in this chapter is not always equally balanced, and presents as poetically complex, provoking and intertwined. To address these entanglements in a colonial context I draw on Peter van der Veer's understanding of imperial encounters as an initial starting point. In his work on religion and modernity in India and Britain, van der Veer suggests that colonial societies develop "in relation to a shared colonial experience." ${ }^{280}$ Van der Veer problematises oppositions such as religious and secular, modern and traditional, and instead argues that binaries conceived as opposites are in fact "deeply entangled and that what is seen to be unconnected is in fact the product of close encounters." ${ }^{281}$ By challenging received narratives of colonialism, nationalism and secularism van der Veer identifies the colonial as a dynamic space of intercultural encounter. ${ }^{282}$ His understanding of colonisation can be applied to the New Zealand context, both in terms of biculturalism and religion. Attending to the entanglements and close encounters of colonisation aid the analysis of the poetry in this chapter.

Van der Veer's interactionist theory is paralleled in New Zealand, for example, in Melissa Kennedy's suggestion that cultural collaboration in art and literature, fostered by the Māori renaissance and a growing Pākehā interest in Māori culture, is not "formed by a binary of two opposites but by cross-cultural influences already within both halves." 283 This observation of "crosscultural" connections acknowledges the bicultural imbrications which resonate within New Zealand's literature. Similarly, Keri Hulme (Kāi Tahu and Kāti Māmoe), in an essay on

\footnotetext{
280 van der Veer, Imperial Encounters, 3.

281 Ibid.

282 Ibid., 13.

${ }^{283}$ Melissa Kennedy, Striding Both Worlds: Witi Ihimaera and New Zealand's Literary Traditions (New York: Rodopi, 2011), xiv.
} 
biculturalism, describes New Zealand poetry as a "literature of contact, of cross-cultural contact." 284 For Hulme, bicultural poetry owes "much to Māori thought and mythology and ways of expression; and because they are written in English an equally incalculable debt is owed to Taha Pākehā."285 Kennedy's “cross-cultural influences” and Hulme's "cross cultural contact” cohere with van der Veer's theory of the entanglement of close encounters in the colonial space. This chapter explores these reciprocal bicultural influences in whenua/land poetry by New Zealand women, identifying a landed religio-spiritual poetics.

\section{Gardens in the Antipodes ${ }^{286}$}

Garden poetry is one area in which evidence of a landed spirituality clearly emerges. Trevor James, in his work on post-colonial New Zealand poetry, suggests that attitudes to land are organised through inherited biblical and theological frames of reference. ${ }^{287}$ His theoretical framework sees poetic articulations of the land as deriving from religious understandings. The origin myth of the Judeo-Christian tradition is the Garden of Eden, Adam and Eve, and the Fall. ${ }^{288}$ The Edenic garden exists as a continuing strain in New Zealand women's poetry but one which has acquired its own Antipodean religious literary roots. In this section I use an early poem by William Pember Reeves to contrast the masculinity of colonial garden poetry with Ursula Bethell's religio-

\footnotetext{
${ }^{284}$ Keri Hulme, "Mauri: An Introduction to Bicultural Poetry in New Zealand" in Only Connect: Literary Perspectives East and West eds. G. Amirthanayagam, and S.C. Harrax (Adelaide: Centre for Research in the New Literatures in English, 1981), 290.

285 Ibid. [Italics in original].

286 Sub-heading borrowed from Ursula Bethell's From a Garden in the Antipodes (1929).

287 Trevor James, “'Pitched at the Farthest Edge': Religious Presence and the Landscape in Contemporary New Zealand Poetry" in Mapping the Sacred: Religion, Geography and Postcolonial Literatures, eds. Jamie S. Scott, Paul Simpson-Housley (Amsterdam: Rodopi, 2001), 131-133; 151-152.

288 These stories come from early chapters in Genesis, the first book of the Christian Bible, which is also the first book of the Pentateuch.
} 
horticultural verse. I read New Zealand women's garden poetry as being an offshoot from a tradition of colonial garden poetry, a deviation I describe as 'Bethellian' ${ }^{289}$ It should be noted that garden poetry is in close proximity to themes of domesticity, which I addressed in chapter one. Garden poetry could be analysed through a domestic lens, but in this chapter, I explore the botanical dimensions of New Zealand backyards; however, similarities here show consistencies between themes.

Colonies can be understood as spaces created to replicate or compensate for another. Where a previous space is considered corrupt, messy or ill-managed, a new space is created to exemplify order, fertility and simplicity. ${ }^{290}$ Gardens serve a similar purpose. In New Zealand, the European garden offered settlers an escape in its enclosure. ${ }^{291}$ Those who found the New Zealand landscape "exceedingly repulsive" and "monotonous in the extreme" alleviated this sense of difference by creating a world of "European and British-style beauty" away from the stretches of unfamiliar land and the fear of the "practically unlimited Pacific Ocean". ${ }^{292}$ Gardens imposed order on the soil, tamed the land, and allowed a retreat into a world of European familiarity. ${ }^{293}$ Out of this love of the British garden, New Zealand garden poetry became an established poetic strain. One of the notable poets of this genre is William Pember Reeves (1857-1932) whose widely anthologised poem "A

\footnotetext{
${ }^{289}$ NB: While Bethell's influence on New Zealand (particularly women) poets has been studied and documented, "Bethellian" is my own coinage and has not been used in any previous scholarship.

${ }^{290}$ I am using Michel Foucault's theory on heterotopias of compensation to conceive this thought. See Anthony Vidler, Michel Foucault and Pamela Johnston, "Heterotopias" AA Files 69 (2014): 18-22; Michel Foucault and Jay Miskowiec, “Of Other spaces” Diacritics Vol. 16, No. 1 (1986): 22-27.

${ }^{291}$ Lynn Staley, The Island Garden: England's Language of Nation from Gildas to Marvell (Notre Dame, IN: University of Notre Dame, 2012).

292 Katherine Raine, “Domesticating the Land: Colonial Women's Gardening' in Fragments: New Zealand Social \& Cultural History, ed. Bronwyn Dalley and Bronwyn Labrum (Auckland: Auckland University Press, 2000 ), 83.

293 Ibid. Here I am also drawing on scholarship on gardens and colonies, see Lynn Staley, The Island Garden: England's Language of Nation from Gildas to Marvell (Notre Dame, IN: University of Notre Dame, 2012); Anne Helmreich, The English Garden and National Identity: The Competing Styles of Garden design, 1870-1914 (Cambridge: Cambridge University press, 2002).
} 
Colonist in His Garden", first published in 1905, is representative of New Zealand settler garden poetry. Strongly in the colonial vein, Reeves represented New Zealand as an open, untouched space to be mastered, coupled with a conceit that the presence of European settlers was the first human contact with the land. This strain of early New Zealand garden poetry is linked to a stoic and unyielding hardiness, in which men "take root" to "Fight Nature for a home". ${ }^{294}$ The masculine approach of such garden poetry is highly allegorical, and the plurality Reeves uses ("we men take root") echoes a larger colonial project. ${ }^{295}$

In contrast to Reeves, Ursula Bethell (1874-1945) began to understand New Zealand as a home, not a New England, bringing together gardening and personal faith. Bethell has come to be a touchstone of New Zealand garden poetry, ${ }^{296}$ and while her work falls outside my time period, her legacy influences later generations of poets whose work I examine. Bethell's poetry establishes, I argue, a distinct feminine tradition of garden poetry in New Zealand. I identify the poetry in this section as working out of a Bethellian tradition. This is not a reified category in these terms, but rather one I follow in order to explore poetry in which religion and spirituality meet gardening.

The scholarship of both Jake Arthur and Peter Whiteford is valuable for understanding a Bethellian tradition. Arthur has argued that Bethell's poetry is a step away from the timbre of original colonial garden poetry and a step towards a Pākehā understanding of the land. ${ }^{297}$ This is not to say that Bethell's garden is not colonial, but she writes as an individual rather than the plural

\footnotetext{
${ }^{294}$ William Pember Reeves, “A Colonist in His Garden” in A Treasury of New Zealand Verse, eds. Alexander, W. F., and A. E. Currie (Auckland: Whitcombe and Tombs Limited, 1926), 58-62.

295 Ibid., [Italics mine]. A similarly New Zealand colonial strand of garden poetry can be seen in Mona Tracy’s 1930 poem "Akaroa" (Alexander and Currie 127-28).

296 See Green, Wild Honey, 367; Jake Arthur, “'Fond human enclosures': Gardening and belonging in Bethell's From a Garden in the Antipodes" in JNZL 35:1 (2017): 35.

297 Jake Arthur, Green Thoughts: The forms, affordances, and politics of garden poetry (Thesis: Victoria University of Wellington, 2016), 87.
} 
"we" of Reeves' "Colonist". ${ }^{298}$ As Arthur recognises, Bethell, as a woman, "is alienated from the masculine paradigm of the settler". ${ }^{299}$ Being unable to fit into the male settler life, she "discards it". ${ }^{300}$ To Arthur, Bethell's work "subtly subverts" the tropes of settler garden verse. ${ }^{301}$ Her poetry is both personal and domestic, and is a significant cultural contribution. Among her poems she searches for a way to articulate her home in New Zealand, and thus her garden becomes a Pākehā woman's understanding of land.

Whiteford has written about Bethell's use of religious allusion in her work, noting that while other New Zealand poets use biblical paradise allegory, Bethell is unique in her ability to allude to Eden "so extensively and yet in such a sidelong and light-hearted fashion". ${ }^{302}$ In his reading of Bethell's From a Garden in the Antipodes, he broadly illuminates moments of paradisiacal allusion which fleck Bethell's poetry. She is not heavy-handed with either her religious imagery or her descriptions of the garden itself, and yet both are very important; the garden is both allegory and reality for Bethell. ${ }^{303}$ Whiteford establishes Bethell as a New Zealand garden poet who brought a lightness of touch to religious allusion, and who blended gardening and religious imagery in a unique manner. ${ }^{304}$ Using Arthur and Whiteford, I understand Bethell as a New Zealand garden poet who articulated a connection with the land through both the language of gardening and the language of Christianity. I suggest that the influence and legacy of Bethell in New Zealand women's poetry has established a 'Bethellian' tradition of women poets writing garden poetry using religious

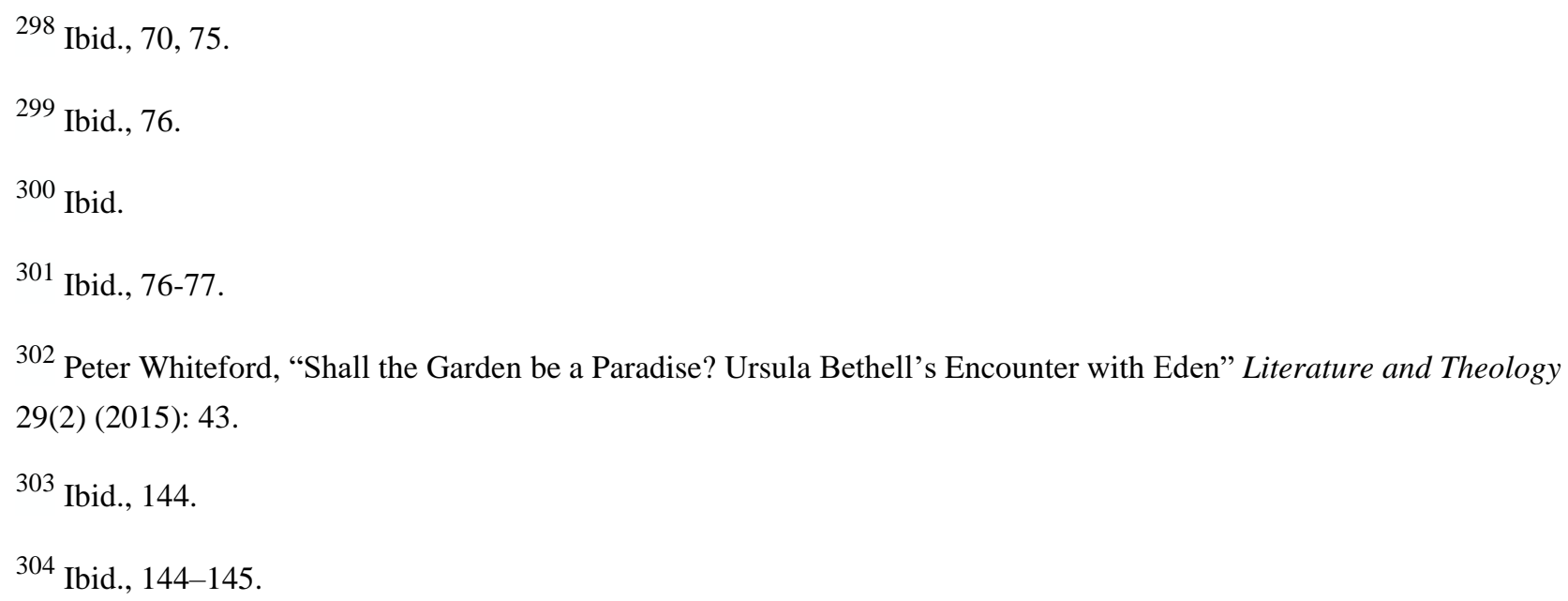


imagery. To explore this, I use examples from Hannah Mettner, Jenny Bornholdt and Sue Wootton, who each present an understanding of the land through the garden, using religious and spiritual language.

Hannah Mettner's poem "Father in the Garden" observes a connection with the land through lawn mowing, depicting this with Edenic language. The tasks of gardening are reassuring; they provide constancy, and both religion and gardening are portrayed as requiring ongoing commitment and amelioration. There are specific allusions to the Garden of Eden as the task of lawn mowing allows the Adamic "father" a controlled spiritual communion with the land, witnessed through the eyes of his children. A precise, bordering on obsessive, attentiveness sees him plucking out weeds "like little bouquets of / wrong. He presents / them to God." 305 The father's attentiveness to the garden is described as an investment in faith as he "wakes up / early in the morning / to get to God first" even though "God's still in bed". ${ }^{306}$ Just as God made humans in the likeness of himself, the father has been heard "murmuring about setting / things in order. He could mow / the garden of Eden into / the image of himself / if he had the time." ${ }^{\text {"307 }}$ As the speaker relates the father's horticultural spirituality, he becomes The Father, controlling his Edenic lawn with omnipotent care:

He knows

how many blades

of grass are in each lawn

the way god knows how many

hairs are on each of our heads.

\footnotetext{
${ }^{305}$ Hannah Mettner, Fully Clothed and So Forgetful (Wellington: Victoria University Press, 2017), 13.

${ }^{306}$ Ibid.

${ }^{307}$ Ibid., 14
} 
The poem reads as an observation of faith through the study of gardening, drawing parallels between the two and is pressed with moments which deepen the reader's understanding of the garden as an allegory of faith, with the ending stanzas specifically alluding to Genesis $2: 2: 308$

\title{
Every Sunday my father takes \\ his rest, twirling a glass \\ of wine between his fingers.
}

\author{
It smells like freshly cut \\ grass. Like two-stroke \\ and sacrifice.
}

The affection and details in her description of the father's gardening agree with a Bethellian tradition in which women poets conceive land through gardening and religious imagery. In "Father in the Garden" religious allegory represents a connection between land, gardener and faith.

A similarly allegorical reading is afforded by Sue Wootton's "Horoeka" but in this poem faith is less managed and far more delicate. "Horoeka" 309 balances liminality, conflict and attempts at control, as the garden becomes a space which both holds and threatens the speaker's religious faith. In this poem the Bethellian tradition is established explicitly, as the poem begins with an epigraphic quote from Bethell: "Faith is a desolate thing." 310 The letter from which Wootton has lifted the line, sees Bethell describe how: "I never have been given that consciousness, which other people so strongly have. I believe [...] but that is not quite the same thing; it is a faith not a joy -

\footnotetext{
308 Genesis 2:2: "And on the seventh day God ended His work which He had done, and He rested on the seventh day from all His work which He had done." (NKJV).

${ }^{309}$ Māori name for lancewood, a tree native to New Zealand.

${ }^{310}$ Sue Wootton, Magnetic South (Wellington: Steele Roberts, 2008), 15. [Italics in the original]; Ursula Bethell, Vibrant with Words: The letters of Ursula Bethell, ed. Peter Whiteford (Wellington: Victoria University Press, 2005), 183.
} 
yet. [...] 'faith is a desolate thing'." ${ }^{311}$ The desolation of Bethell's quote is figuratively represented in Wootton's poem through the "knucklebone stumps of trees" which stand damp under the "uniformly grey" sky. ${ }^{312}$ The absence of life in the garden is oddly present:

The birds today are - where?

- the garden silent, woven here and there

with spider's silk. No spiders

on the net. No insect flutters. ${ }^{313}$

The loneliness of the garden parallels that of the Bethell quote, and there is a gothic timbre in the description of how the "light is ghostly, / particulate with mist". 314 The lancewoods (Māori, horoeka) are the only plants in the silent garden that seem to be alive, but they are described with an abrasive language which is juxtaposed against a fragile Church imagery:

The lancewood

serrates raw air with stiff leaf swords.

At each rough tip, pent, poised,

a bead of water: still bell, locked cloister,

a luminescent book of common prayer. ${ }^{315}$

The beads of water which hold the Christian symbols are threatened by the violent lancewoods, and the fragility of faith is accessed through the garden. These symbols suggest silence and lifelessness;

\footnotetext{
${ }^{311}$ Bethell, Vibrant with Words, 183. This letter, in particular, is on the subject of the death of her friend and companion Effie Pollen.

312 Wootton, Magnetic South, 15.

313 Ibid., 15.

314 Ibid., 15.

${ }^{315}$ Ibid.
} 
the "still bell" does not ring, and no one walks down the "locked cloister". The garden in "Horoeka" is not one of comfort and seclusion, as it was to many settlers, but rather Bethell's

"desolate" faith is echoed in Wootton's lancewoods which threaten to tear apart the membranes of the water beads containing the emblems of Christianity:

Oh desolate faith - to shake the lancewood, rip the membranes, scatter the psalms in shards. ${ }^{316}$

"Horoeka" echoes James' theory that understandings of land originate in religion. While Wootton is not describing an Eden, or if she is it would appear to be a postlapsarian one, her use of Christian and garden imagery evokes the Genesis story. By quoting Bethell, Wootton recognises the tradition of Christian garden imagery in New Zealand poetry. In "Horoeka" the garden is a catalyst for spiritual reflection, and, in this case, spiritual disquiet.

The garden as a place of sadness and reflection is also evident in much of Jenny Bornholdt's poetry. ${ }^{317}$ Bornholdt could be considered an epitome of a contemporary garden poet and, although her work delves into many other genres, the garden poems are arguably the most vivid depictions of connection to land throughout her oeuvre. Her garden poetry is strongly in the Bethellian tradition but less explicitly religious and rather a subtle, spiritual verse which describes the garden as a place of personal reflection and growth. Bethell is present in Bornholdt's poetry. This is shown very consciously in the poem "The Rocky Shore", in which the speaker describes planting "a fig, olive and bay / in memory of Mary Ursula Bethell".318

\footnotetext{
316 Ibid.

${ }^{317}$ Confessional garden poetry is particularly present in Bornholdt's collection The Rocky Shore.

318 Jenny Bornholdt, The Rocky Shore (Wellington: Victoria University Press, 2008), 21.
} 
The first poem from Bornholdt's collection These Days is an example of a garden poem in which the garden acts as a spiritual sanctuary. ${ }^{319}$ The garden begins as physical but becomes metaphorical and spiritual. The poem opens by describing how "It was a year of great sadness / in the garden" and details a cacophony of loss and pain; the death of sisters, divorce, illness and the loss of pet animals, so that eventually "helpless [...] we wept". ${ }^{320}$ The last section of the poem details how a "vase / entered our lives / as a body of light / its white flowers a kind of peace we craved". ${ }^{321}$ This description has greater intertextual resonance if the reader is aware of the origin story of the mentioned vase. A note from Bornholdt explains that the vase originally belonged to Ursula Bethell, who customarily filled it with white flowers. The vase was given to Bornholdt by poet Jocelyn Harris, on the proviso that it will be given to another woman poet in time. ${ }^{322}$

As the poem ends, the vase becomes a totemic avenue out of sadness, and its description as "a body of light" with its "white flowers" allows the poetry to shimmer with solace after the grief described in the earlier lines. The continued lines see the vase become a transcendent gateway:

its white flowers a kind of

peace we craved and

entered as the gate

to another garden

on a hillside, tended by women

who looked up

from roses to mountains

and saw snow

\footnotetext{
${ }^{319}$ Few of the poems in this collection are titled, and therefore I take the first line, "It was a year of great sadness", as the title of the poem.

320 Jenny Bornholdt, These Days (Wellington: Victoria University Press, 2000), 7.

${ }^{321}$ Ibid., 7-8.

322 Bornholdt, “Acknowledgments" in These Days, 70.
} 
bloom there. ${ }^{323}$

The Edenic timbre of entering "another garden" through the vase encourages an image of going back to a prelapsarian paradise. The language affords a religious and spiritual reading, only increased by the connection between Bornholdt and Bethell through the vase. The image of the women tending the garden who look "up / from mountains to roses" has parallels with Bethell's poem "Pause" in which the speaker, while gardening, looks up "at the mountains, / And muse[s] upon them." 324

All three poems above denote a religious and spiritual connection to land through the garden, while also being consistent with a wider tradition of garden verse in New Zealand women's poetry. Although Mettner's "Father" does weed the lawn, I would argue that all three poems lack a colonialist's desire for mastery of the land. If anything, Mettner's "father" has a faithfulness to the grass which suggests commitment rather than control, and in "Horoeka" the lancewoods appear to have a greater authority than the speaker. In all three poems there are elements of fear: the constant attention of the "father" in Mettner, the fragile faith of Wootton's "Horoeka", and Bornholdt's escapism into an imaginary garden, suggest that the land is not necessarily always a paradigm of stability and that the garden has its strains as well as its solaces. Bearing in mind the theological traditions of fallenness and alienation that resonate with the narrative of Eden's garden, this is not unsurprising. Elements of Edenic fallenness are present in the above examples, particularly in Wootton's scattered psalms and Bornholdt's description of movement out of a garden. Gardens in New Zealand women's poetry have become something other than attempts at English utopias.

\footnotetext{
323 Ibid., 8.

${ }^{324}$ Ursula Bethell, Ursula Bethell: Collected Poems ed. Vincent O’Sullivan (Wellington: Victoria University Press, 2014), 2; Also see; Masami Nakao “"The Gate to Another Garden': Text and Image in Jenny Bornholdt's These Days" in Writing at the Edge of the Universe, ed. Mark Williams (Christchurch: Canterbury University Press, 2004), 156-159; There is a similarly Bethellian cadence in Rosemary Menzies' poem "Unto the Hills", see Rosemary Menzies, I Asked The Moon: Poems (Auckland: Rosemary Menzies, 1981), 5.
} 
Bethellian garden poetry evidences the tradition of a religio-spiritual landed poetics in New Zealand women's poetry.

\section{Whenua Poetry: Mater and Matter}

In this section I address a Māori understanding of land mediated though maternal and feminine whenua stories. Poems by Roma Potiki and Keri Hulme demonstrate the constancy of personified land written by Māori poets. "Waitara Canticle" is written by a Pākehā poet, Bernadette Hall, but the land is similarly personified and feminised, and expresses an awareness of Māori understandings of land, as well as cognisance of colonial land-damage.

New Zealand women's garden poetry has an intertextuality and an emic quality, whereas whenua poetry, which frequently employs code-switching to te reo Māori, reads far more as an etic poetry. More than in the garden poetry, whenua poetry exemplifies a biculturalism and an imbrication of Pākehā and Māori cultures, as well as Māori and Christian mythology. However, this biculturalism comes with its complications. Anahera Gildea has articulated concerns that codeswitching is not adequately understood by a Pākehā readership and notes that when Māori poets code-switch to te reo, "elements culturally specific to Māori will be glossed over, whitewashed, deemphasised, trivialised or minimised." ${ }^{325}$ Similarly, Kelly Lambert has warned how, when investigating the land poetry of Māori women poets, "academic fingers never [go] more than skin deep". ${ }^{326}$ There are often "Eurocentric" suggestions that Māori land poetry is a brief "retreat" from the real world into the spiritual, when a more culturally competent reading would be to see the

\footnotetext{
325 Anahera Gildea, "Kōiwi Pāmamao - The Distance in our Bones" The Pantograph Punch https://pantographpunch.com/posts/bones (accessed January 13 2020).

${ }^{326}$ Kelly Lambert, Calling the Taniwha: Mana Wahine Māori and the Poetry of Roma Potiki (Thesis: Victoria University of Wellington, 2006), 32.
} 
poetry as celebrating a prevalent and ongoing connection with the land in the everyday. ${ }^{327}$ Both Gildea and Lambert's points draw attention to the complications of proficiently analysing bicultural poetry.

In Māori origin myth, Ranginui (the Sky Father) and Papatūānuku (the Earth Mother) were in an embrace until their children decided to push them apart. ${ }^{328}$ Ranginui and Papatūānuku were forced away from each other and their children were able to live in a world of light (Te Ao Mārama). ${ }^{329}$ Papatūānuku, therefore, is whenua, meaning that whenua has maternal origins since Papatūānuku is the 'mother' of everything, and land is therefore considered whanaunga, or 'kin'. ${ }^{330}$

Beyond New Zealand, this understanding of the earth as a mother is a widely held image across diverse cultures and religions, but one which was widely suppressed in a shift Vandana Shiva describes as from "mater to matter". ${ }^{331}$ The concept of the earth as feminine and maternal was seen as a mental barrier to projects of colonialism, building and deforestation. More recently, ecological movements in the West have begun to use the image of the earth mother, or goddess, to mobilise activity around ecology and climate, and the re-appropriation of this Terra Mater motif has been a feature of ecofeminism and climate activism.

In the following poetry, which focuses on the feminisation of land, it is not so much Shiva's mater vs matter debate that presents itself, as much as a mater and matter ideology, in which the

\footnotetext{
327 Ibid., 32-33.
}

${ }^{328}$ Nelson Wattie, "Papa and Rangi" in The Oxford Companion to New Zealand Literature Online eds. Roger Robinson and Nelson Wattie (Oxford University Press, 2006). https://www.oxfordreference.com/view/10.1093/acref/9780195583489.001.0001/acref-9780195583489 (accessed October 17 2019).

329 Ibid.

330 Tui Cadogan, “A Three-Way Relationship, God, Land Place: A Maori Woman Reflects” in Land and Place: Spiritualities from Aotearoa, eds. Helen Bergin and Susan Smith (Auckland: Accent, 2004), 30.

${ }^{331}$ Vandana Shiva, "Women in Nature," in Space, Gender, Knowledge: Feminist Readings (London: Arnold, 1997), 176. 
land is durable and constant but concurrently feminine and maternal. There is evidence of a tradition in New Zealand women's poetry, in which the Māori mythological understanding of whenua comes through in its personification as maternal. The land is both the physical, material substance on which we stand, and a feminine, maternal presence, and the acknowledgment of either of these features does not negate the other. Like the Bethellian tradition in New Zealand women's garden poetry, this appears to be a gendered style.

In the work of Roma Potiki (Te Rarawa, Te Aupōuri and Ngāti Rangitihi) Papatūānuku is a recurring character and over three of her poems the centrality, as well as the corporeality, of whenua becomes established. In "Dark composure" Potiki describes Papatūānuku as "whenua, whaea o nga tangata katoa" which can be translated to "land, mother of all people". ${ }^{332}$ This recognition of whenua as maternal connects to the mater and matter concept, aligning with both components. Potiki's poem "Papatuanuku" sees the land described as both land and body. A recurring word in this poem is "I", as the centrality of whenua as a self-possessed and autonomous character is constantly reaffirmed:

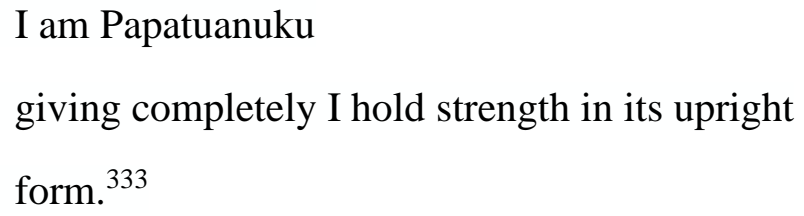

The choice of first-person pronoun sees the poet give the agency of the speaker-role to the land. Rather than the speaker being positioned on or above the earth the speaker becomes the land, and the reader is spoken to by a character who declares that "When the rest is gone / you will know me." 334 There is a strongly corporeal sense of whenua; it is both body and earth, and the two are

\footnotetext{
${ }^{332}$ Roma Potiki, Shaking the Tree (Wellington: Steele Roberts LTD, 1998), 69. I say "can" as the plurality of meanings "whenua" holds leaves the translation somewhat open to the reader.

${ }^{333}$ Ibid., 26.

${ }^{334}$ Ibid.
} 
synonymous and interchangeable. Potiki emphasises the corporeality of Papatūānuku, describing her bodily framework: a face "made of bones", an "eternally stretching stomach", and skin which is "press[ed]" and "tread[ed]" upon. ${ }^{335}$ The personhood of the land is central but the substance of it is not negated, illustrated in the lines: "I need no definition / I am Papatuanuku, the land."336

In another poem, "Te Whenua ki te Whenua", Potiki asserts that "The body and the land are one. There is no separation." ${ }^{337}$ This inseparability of the body and the land places the two in equilibrium, with the land conceived, once again, in corporeal terms. In these three poems, despite the speaker's spiritual and filial connection to the "mother of all", there is no doubt that the land is land. There is an earthy substance to the representation. Potiki's assurance that "the body and the land are one" articulates a spirituality of both mater and matter.

Like Potiki, Keri Hulme's poetry understands whenua as a feminine entity, with the maternal emphasised in her poem "Papatuanuku e tu!". Land is both spiritual and material, and there is a suggested dependency and symbiosis between the land and the people who live on it:

my mother breathes every breath

you breathe I breathe them all/others

with us/without ${ }^{338}$

The spacing play in these lines emphasises a symbiotic relationship between land, humanity and breath, with the "my mother" calling back to the origin story of Papatūānuku. This is highlighted further in the description of how Papatūānuku has "us under her skin / swarming and on her skin warming / all the world yea even unto the volcano's lip." "339 The semi-parasitic description of land

\footnotetext{
335 Ibid.

336 Ibid.

${ }^{337}$ Roma Potiki, Oriori (Auckland: Tandem Press, 1999), 62.

${ }^{338}$ Keri Hulme, Strands (Auckland: Auckland University Press, 1992), 33.

${ }^{339}$ Ibid.
} 
inhabitation is similar in tone to the "press" and "tread" described in Potiki's "Papatuanuku".

Again, the "skin" of Papatūānuku is mentioned here, and this epidermal imagery is both spiritual, in that it enhances the idea of personhood of the land, and directly physical.

The origin story of Papatūānuku is not the only one that Hulme describes, nor the only one in Māori mythology which involves feminine representation. Hulme plays with both Christian and Māori allusion in her long-form poem "Fishing the Oleiria tree". Hulme merges Māori and Christian creation stories, using words which resonate with biblical text and also allude to the myth of Hine-ahu-one, or the woman shaped from sand:

Feel the mud under your toes. Feel this deep warm inviting mud - no shells or sharp things to harm your skin - just a squelching friendly mud. In the beginning there was mud. In this end, mud. ${ }^{340}$

Hine-ahu-one is a Māori mythological character, the first woman, who is created out of mud or sand by Tane. The choice of "in the beginning" references Genesis 1:1, and a similarity can be drawn here between Hine-ahu-one and Adam. In the Genesis story of creation, the first person, Adam, is formed from ‘Adamah' (the earth). ${ }^{341}$ Therefore in these lines Hulme's mud alludes to both Hineahu-one and Adam, as both have earthy origins. Hulme pulls these similar mythological concepts together in ways which evidence a biculturalism in her poetry.

This Māori-Christian merging can also be seen in Bernadette Hall’s "Waitara Canticle". Hall grounds this poem in the imagery of the personified feminine New Zealand landscape and the history of colonial damage, but with a clear connection to Christian heritage. ${ }^{342 ~ " W a i t a r a " ~ r e f e r s ~ t o ~}$ a town in the Taranaki region, one which was the site of the outbreak of The First Taranaki War in

\footnotetext{
${ }^{340}$ Ibid., 20.

341 'Adamah' is Hebrew; similarly, in Latin the word 'humans' comes from 'humus' meaning 'earth'.

342 Bernadette Hall, The Merino Princess: Selected Poems (Wellington, Victoria University Press, 2004), 78.
} 
1860, and subsequently included in land confiscated under the New Zealand Settlements Act 1863. "Waitara" is juxtaposed against the Christian "canticle" which is traditionally a hymn using a biblical text. ${ }^{344}$ Throughout the first two stanzas, Hall continues to contrast te reo Māori with Christian vocabulary:

Someone has dug with a patu

a ditch in the sunlit meadow

of her wide forehead. See

the ashy Lenten cross

she delights in wearing,

the shark-toothed necklace. ${ }^{345}$

Like the land in Potiki and Hulme's poems above, Hall personifies Waitara as a feminine presence, but one who is decorated with bicultural images and symbols. A patu is a traditional Māori club, and this is contrasted with the image of a "Lenten cross". Hall is likely alluding to the religious ritual of marking the forehead with ashes, which is practised in various Christian traditions during a service on Ash Wednesday, the first day of Lent. This evokes the idea of a time of fasting and lament and the "ashy" may symbolise mourning and loss. Waitara's tongue is described as "a sacred vessel", which is revealed when "she opens her dark / throat" and there is an "odd / singing of the air as it moves / through the clerestory". ${ }^{346}$ The femininity of the land is later emphasised as Waitara is described as "Cheryl Moana / Marie, loosening her queenly / fretted throat", adopting the

\footnotetext{
343 An Encyclopaedia of New Zealand, “Waitara,” https://teara.govt.nz/en/1966/waitara (accessed September 1, 2018).

344 A canticle is traditionally a hymn or chant, usually involving a biblical text, "Canticle, definition b.", Oxford English Dictionary Online.

${ }^{345}$ Hall, The Merino Princess, 78.

${ }^{346}$ Ibid. "Clerestory" is the upper level of a cathedral or large church, "Clerestory, definition 1. a.", Oxford English Dictionary Online.
} 
title of New Zealand performer John Rowles' song and bringing a paradoxical pop-song tonality to this religious "canticle". The poem ends with the stanza:

hey, hang on a minute,

we'd better all listen

this time, don't you reckon! ${ }^{347}$

This relaxed, demotic interrogative is not clear about what "we" should be listening to, however, the "singing of the air", the reference to Rowles' song, the imagery of the throat "loosening", all bound in the poem's "canticle" title, suggest an illusory aural quality existing within the poem. Hall pulls together Māori and Christian religious imagery, using both cultures to create a mater and matter representation of whenua.

In all these examples there is an evident biculturalism. The code-switching between English and te reo Māori, and the merging of Māori, Christian and Pākehā imageries, is evidence of a "cross-cultural contact". ${ }^{348}$ This biculturalism appears to arise in the tradition of whenua poetry, far more than it does in garden poetry. The images of feminine land differ in their characterisation, but Lambert's reading of Māori poetry as characterising a spiritual connection with the land as solid, dependable and enduring rather than only fleetingly spiritual, is consistent with the examples above. The mater vs matter debate appears to be redundant in these poems. Instead, the idea of the earth as mother remains a feature across the poetry, and the matter component is subsumed into the idea of the feminine whenua.

\section{A Return to the Source ${ }^{349}$}

\footnotetext{
${ }^{347}$ Hall, The Merino Princess, 78.

${ }^{348}$ Hulme, "Mauri”, 29.

${ }^{349}$ Sub-heading borrowed from Roma Potiki's poem "Tarawera" in Stones in Her Mouth.
} 
In this final section I explore poetry which shows Māori and Christian spiritual understandings of land brought together still more, but in relation to birth and death. ${ }^{350}$ There is a confluence of understandings of land through the rituals associated with these life events. The garden poetry of the Bethellian tradition meets Māori understandings of birth rites in Anne Kennedy's "Whenua" poetry, and this is echoed in Bernadette Hall's "Pansies" in which gardening articulates grief in response to death. In Anahera Gildea's Poroporoaki, Christian and Māori imagery is combined to describe the journey, over land, of a soul to Hawaiki. Tayi Tibble's "Hawaiki" amalgamates the representation of Hawaiki and Edenic imagery, responding to birth through pondering on death.

In the poems of Gildea (Ngāti Raukawa-ki-teTonga) and Tibble (Te Whānau-āApanui/Ngāti Porou), the Māori understandings of what happens after death are also crucial. There is a Māori belief that when a person dies, their wairua (soul) journeys to Te Reinga (Cape Reinga), the leaping place, at the far end of the North Island. The journey is a detailed one, with the wairua climbing up hills, crossing streams, and moving along rocky capes. ${ }^{351}$ There are conflicting opinions as to what happens to the wairua after this journey; however, a major tradition asserts that the wairua crosses the ocean to the distant homeland of Hawaiki. First, the currents take the wairua to Manawa-tawhi, and the soul will look back and mihi to its relatives and the land and from there move out towards Hawaiki. ${ }^{352}$

In western and Christian traditions burial is a rite primarily reserved for the dead. For Māori, however, burying the placenta after the birth of a child reinforces the relationship between the child

\footnotetext{
${ }^{350}$ For another discussion of Birth and Death in New Zealand poetry, see Green and Ricketts, 99 Ways Into New Zealand Poetry, 526-536.

${ }^{351}$ Margaret Orbell, The Illustrated Encyclopaedia of Maori Myth and Legend (Christchurch: Canterbury University Press, 1995), 206-208.

352 Ibid., 208. This story has variations, but the northern journey to Te Reinga is generally accepted by most.
} 
and the land of their birth. ${ }^{353}$ Whenua shares the dual meaning of land and placenta, and the connection between the words is not simply an equivalency: rather, there is an understanding of the shared physicality and importance of both the land and the placenta. The burial of the placenta in the land emphasises this connectivity. ${ }^{354}$ In a poem by Potiki, "Tarawera", the interconnectivity and synonymity of "whenua" (land) and "whenua" (placenta) is emphasised in the description of how "a woman / plants a whenua / skin to skin / in black and white / a return to the source". ${ }^{355}$ Noting Potiki's use of "plant", often a tree is planted on top of the placenta in order to mark the spot, symbolically adding to the land and using the fertility that the placenta provides.

Kennedy's collection Sing-song is a sequence detailing a mother's experience of her young daughter's eczema. In a collection titularly crisscrossed with mythological references to both Māori and Christian traditions, two poems, "Whenua (1)" and "Whenua (2)," describe the mother and her Māori husband planting their daughter's "first / Papatūānuku". 356 The baby’s whenua is initially planted in a flower pot in the garden, but her husband suggests that the reason their house will not sell is because the whenua is tying them to the land: "the whenua / it's keeping us here." ${ }^{357}$ They replant it in Karekare by a "waterfall and [a] lovely pool" and plant "a cabbage tree from Up North on top". ${ }^{358}$ As the family leaves, the mother begins to worry about leaving the placenta, and the speaker's perspective shifts and recalibrates in response to this act of burial:

The mother fretted a bit about the girl's

\footnotetext{
353 "Whenua - the placenta", Te Ara - The Encyclopaedia of New Zealand https://teara.govt.nz/en/papatuanuku-theland/page-4 (accessed October 17 2019).

354 As a poetic motif in New Zealand women's poetry the burial of the placenta is recurrent. See Angela Andrews' "Whenua" in Echolocation (Wellington: Victoria University Press, 2007), 47.

${ }^{355}$ Roma Potiki, Stones in Her Mouth (Auckland: IWA Associates, 1992), 37.

356 Anne Kennedy, Sing-song (Auckland: Auckland University Press, 2003), 25.

357 Ibid.

358 Ibid., 25-26.
} 
whenua left there in the dark, in the lonely

beautiful place, and understood for the first time

place isn't prettiness, isn't a tinkling waterfall[.] $]^{359}$

The pretty place they select carries a greater significance after the daughter's whenua is planted there, and the picturesque is rendered unimportant in contrast to the connection that the land, and the placenta buried there, now has with the family. The mother continues to be "niggled by the whenua, leaves it there for years" and avoids returning to the spot so that the land "becomes mythical / the pool, the waterfall, her abandoned atoll". ${ }^{360}$ The sequence culminates in "Whenua (2)" when the family return to Karekare to visit the whenua. They are "expecting / nothing, no tree" but arrive to see the cabbage tree "straight, unmistakable among the / low flax, taller, like a big sister / [...] nodding now and then / unaware of its perfection". ${ }^{361}$ The reaction to the tree interacts with the surrounding land as the family "cry out / Look! Look at her tree! Their voices / bouncing like unaccustomed smiles off the / stern rock behind the waterfall." ${ }^{362}$ After a sequence of poems in which a mother attends to her daughter's health, ministering to her skin with blind faith in different treatments, this last "Whenua" poem connects the eventual health and growth of the child with the growth of the whenua-tree.

"Whenua" 1 and 2 suggest the spiritual potential of the land. By placing the "Whenua (2)" poem at the end of this sequence Kennedy places a Māori landed birth rite at the conceptual centre of the collection. Given that the poems are pervaded with the tension of having an unwell child, the planting of the placenta reads like an act of faith as well as a traditional rite. The knowledge that the

\footnotetext{
359 Ibid.

${ }^{360}$ Ibid., 27.

361 Ibid., 123.

362 Ibid.
} 
whenua-tree has grown comes at the same time as the acknowledgement of her daughter's new wellness. In this way the whenua poetry reads as an articulation of life events.

Bernadette Hall's "Pansies” expresses a similar connection between burial and spiritual articulation, but where in Kennedy's poem the tree is an image of health and growth, in "Pansies" the planting of seeds sees the garden, and its flowers, act as a conduit for the expression of grief. Hall uses the garden as an enclosed physical and conceptual space where spiritual understanding is accessed through horticulture, opening with the speaker describing the death of her father and her mother's grief:

my mother

when

my father

died

dried

the tawny

fronds of

her sorrow

$\&$

stored them

in silence 363

The "fronds of her sorrow" begin as a metaphorical flower-pressing of grief, but the following stanzas see the speaker planting pansies, which become a metonym for the death of the father:

that summer

${ }^{363}$ Hall, The Merino Princess, 12. 
I planted

pansies

all round

the house

a moat of petals

even now

my mother

speaks of

my father

in

directly

praising

the petals

of pansies $^{364}$

The enjambment of "In / Directly", leaving the meaning ambiguous, is in keeping with the rest of the poem, which treats grief both directly and indirectly. Hall is not referencing a specific tradition in "Pansies" but the similarities between it and the "Whenua" poems suggest similar spiritual responses to death. While on different ends of the linearity of life, both the burial and planting of trees and flowers create a material and spiritual connection to important life events. These examples suggest a tendency for some women poets to return to the theme of land when talking about birth and death rites; the return of Kennedy's "mother" to the whenua symbolises health, and the return of Hall's "mother" to the image of the "pansies" articulates loss.

364 Ibid. 
As discussed earlier in this chapter, Māori literary patterns have led to an understanding of different modes of storytelling in New Zealand literature. Linearity and sequential pathways of thought are often replaced with circular narrative patterns in keeping with Māori oral traditions and mythological influences. This circularity can be viewed in the two previous poems in which birth involves a tradition of burial, and death is referred to through the presence of the living pansies. In the following two examples this circularity is presented again, but is contrasted with Christian form and imagery. ${ }^{365}$ In Anahera Gildea's Poroporoaki to the Lord My God: Weaving the Via Dolorosa, the Stations of the Cross are used as way markers as she knits the Via Dolorosa with the Māori spiritual journey to Hawaiki. In Tayi Tibble's poem "Hawaiki”, birth and death are explored in the same breath, with the birth of a child prompting an internal investigation into death through the imagery of both Māori and Christian origin stories.

Gildea's Poroporoaki is an ekphrastic long-form poem, written in response to a series of paintings by New Zealander Colin McCahon, Walk (Series C). ${ }^{366}$ The paintings were inspired by the Stations of the Cross, and Gildea's work takes on the same structural form, comprising fourteen short poems, one on each page. ${ }^{367}$ Poroporoaki tracks a wairua across the fourteen poems, or Stations, amalgamating Christian and Māori religious imagery. The wairua sometimes takes on the

\footnotetext{
365 The poetry of Hinemoana Baker (Ngāi Tahu, Ngāti Raukawa, Ngāti Toa and Te Āti Awa) can also be read as using whenua/land imagery, circular patterns and spiritual articulation. See Hinemoana Baker, mātuhi| needle (Wellington: Victoria University Press, 2004).

${ }^{366}$ McCahon's Walk was painted in 1972 in memorial to his friend, the New Zealand poet James K. Baxter. As in the Bethellian garden poetry, there is intertextuality here.

367 The Christian Stations of the Cross are icons or prayers depicting Jesus Christ on the journey to his crucifixion. This imagery has grown out of imitations of the Via Dolorosa, or the way of suffering, which was the final route Jesus was believed to have walked in Jerusalem. Gildea's collection appears to be the second published collection of New Zealand ekphrastic poems in response to the stations of the cross. In 2006 a collection was released with images of Llew Summers' sculptures of 'The Way of the Cross', from the Cathedral of the Blessed Sacrament in Christchurch, accompanied by poems by Bernadette Hall written in response to Summers' sculptures. Gildea's collection came a decade after Hall's.
} 
presence of a Christ figure, with biblical references displayed across the poem, but this is interlaced with references to journey to Hawaiki and the imagery of Māori weaving:

This sackcloth taonga will be your anchor now, (let go the weight of humanity on your black cross) it will cast threads from the living all the way to Manawatawhi - where you'll take your last look. ${ }^{368}$

There is an imbrication of culture references in "sackcloth taonga", which refers to both a woven korowai (cloak) and is an allusion to the biblical 'sackcloth and ashes', a metaphor for shame. As the poem continues, the korowai appears to fray:

The unsteady warps and welts of this cloak have caused the tāniko along the bottom to crack the horizon.

But Muriwai nurtures the embers of our iwi, and this korowai will take on the spirits of every great leader and warrior who walks it. ${ }^{369}$

"Muriwai" refers to an ancestor who came to New Zealand from Hawaiki, and by invoking this Gildea ties back into a cyclical origin story in which souls both come from Hawaiki and return there. Through this, Gildea emphasises how the Māori concept of afterlife, or other life, is not katabatic or anabatic as many other cultural afterlives are. Rather, there is a horizontal concept of travel and return which is imaged in this stanza. The horizontal pathway of spiritual travel over land fits with the progress of the Via Dolorosa. Within the Stations of the Cross there are the three falls,

\footnotetext{
${ }^{368}$ Anahera Gildea, Poroporoaki to the Lord My God: Weaving the Via Dolorosa: Ekphrasis in Response to Walk (Series C) by Colin McCahon (Wellington: Seraph Press, 2016), 7.

${ }^{369}$ Ibid., 5.
} 
three times when Christ is said to have stumbled under the weight of the Cross. ${ }^{370}$ In poem "XII" Gildea alludes to one of these falls:

And you will recognise that

a black line separates the milk of the sky, sheepish and shrouded,

from the knuckled gravel, where you took your first fall.

It was expected, bro. No shame in trying to carry that tau alone, ${ }^{371}$

The description of the milky sky and the "knuckled gravel" describe the horizon on the way up the islands to Te Reinga, as the sky and earth come together. "Tau", which in this context reads like a Māori word but in fact is not, means cross or crucifix. ${ }^{372}$

Three more Station-stanzas develop the journey, with further focus on the sky and the sea, emphasising the landed-travel in this journey to the afterlife:

If you follow the next break in the horizon

you may think it's an invitation to walk out into the wet cold ocean

and lose your breath underwater.

It is not. ${ }^{373}$

Instead look to where the sky has taken up tone

long and arid, clouds formed from my fists, arguing with our tūpuna in there.

\footnotetext{
${ }^{370}$ A poem by Elizabeth Smither, "The Veronica Veil Technique", is another example of the Via Dolorosa in New Zealand women's poetry, in which the sixth station is narrated through the first-person of Saint Veronica, see Elizabeth Smither, Professor Musgrove's Canary (Auckland: Auckland University Press, 1986), 10.

${ }^{371}$ Ibid., 8.

372 Gildea is using "tau" as an ancient, pre-Christian transliteration of "cross' (TAU, THE LETTER "T". http://nzetc.victoria.ac.nz/tm/scholarly/tei-Stout67-t9-body-d1-d4.html). Here, she is in conversation with Colin McCahon, who used a large black letter ' $\mathrm{T}$ ' to symbolise the Christian cross. While reading "tau" as 'cross' is appropriate given the context, "tau" is also a Māori word but no rendering of it allows for translation to cross or crucifix.

${ }^{373}$ Gildea, Poroporoaki, 10.
} 
They don't want you to know ${ }^{374}$

That we do fall off; into the blackout, where the shade has been drawn. ${ }^{375}$

The image of "fall[ing] off" further crafts the idea of landed spiritual travel to the afterlife, in which the land eventually reaches its end. With the last three poems, the speaker looks out towards the three islands off Te Reinga, and articulates a communion with whenua, as well as picking up on the idea of the "bones" and body of the previous Papatūānuku poetry:

Here we both are, man,

kneeling at the foot of all this white,

at the beach broken by Christ already,

facing the grief; ${ }^{376}$

I expect to see your tiny boat out there on the crooked horizon. ${ }^{377}$

Sometimes it is enough

to sit and look out.

Other times you have to walk

across bone, stone and shell. ${ }^{378}$

Using Christian imagery and Māori belief, Gildea creates a richly textured spiritual discourse drawn from different representations of spirituality and landscape. The concept of "weaving the Via Dolorosa" is subtly continued throughout the poems, as the motif of weaving a cloak, and weaving

\footnotetext{
374 Ibid., 11.

375 Ibid., 12.

376 Ibid., 14.

377 Ibid., 15.

378 Ibid., 16.
} 
together both Māori and English vocabulary and Māori and Christian religious references, are all sustained. Gildea's poem perfectly presents a bicultural poetry. The journey of the wairua to the afterlife is a spiritual understanding of land, which is articulated here through bicultural religious imagery.

Tayi Tibble's "Hawaiki” presents a similarly bicultural poetry, but here birth, rather than death, is the starting point, as the naming of a child prompts a discussion of the afterlife:

My mother, tired

from pregnancy and being

alive, named her last son

Hawaiki

like the paradise.

Some people say

it is where we go

when we die[.] $]^{379}$

Paradoxically, Tibble's birth poem immediately comes back to death. She describes, not unlike Gildea's Poroporoaki, the journey of the soul to Hawaiki, and how it dives "straight off the edge / of Cape Reinga and into / the point where the sky / hangs so heavy with spirits / that it touches the sea". ${ }^{380}$ This echoes Gildea's description of "falling off; into the blackout" at the edge of the sea. Just as Gildea invokes Muriwai, Tibble acknowledges the stories of ancestors coming from Hawaiki:

Other people say

that is where we were

\footnotetext{
${ }^{379}$ Tayi Tibble, Poūkahangatus (Wellington: Victoria University Press, 2018), 78.

${ }^{380}$ Ibid.
} 
before we came here

by waka, or whale, perhaps[.] $]^{381}$

Bringing together Māori and Christian allusions, she describes Hawaiki as "where we were [...] / before we discovered / Like Eve / God's forbidden fruit / in the shape of an I." ${ }^{382}$ The Edenic simile speaks directly to the bicultural context.

In the last stanzas Tibble brings back the concept of birth from the opening lines, but knits it together with death with a cyclical corporeal image. The speaker posits that she thinks "it must be a womb / where everything is born / and returns to." ${ }^{383}$ This description links back to the Papatūānuku and whenua poetry. Anne Kennedy’s description of a whenua as a "fïrst Papatūānuku" connects childbirth and the land in a cyclical manner, and Tibble's "womb" is similarly circular. Both bring together the idea of birth, death, land and bodies. "Life and death" are then described as "the colour of red. / They are the colour / of a cosmic heartbeat / rising on his fresh baby flesh". ${ }^{384}$ Here red can be understood as a biblical reference, referring to the Hebrew 'Adamah', from which we get Adam, which can translate to 'red earth'. Tibble's poem weaves together the different traditions discussed in this chapter; using the premise of birth, she explores death through both Hawaiki and Edenic imagery, plaiting together Bethellian and whenua poetry.

Both poems by Gildea and Tibble exemplify a poetry of "cross-cultural contact" and bicultural imbrication. The afterlives conceived in each are represented through imagery which shows the "cross-cultural influences already within both halves". ${ }^{385}$ Both the Christian imagery of the garden and the Māori imagery of the journey to Hawaiki centre on the concept of land. The

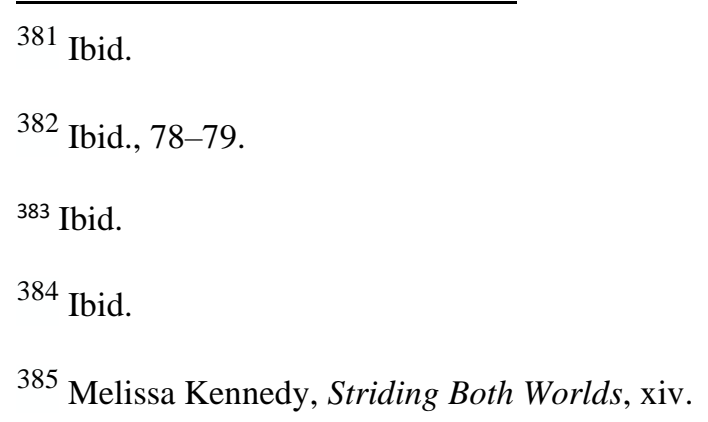


cultural imbrication explored in this last section suggests the prevalence of a poetic tendency to return to religious understandings when presented with both life and death.

\section{Conclusion}

Land is a theme, more than any other in this thesis, in which New Zealanders are prepared to explicitly engage in a spiritual way. However, the examples in this chapter show a poetry which is engaging both spiritually and religiously with bicultural understandings of land. ${ }^{386}$ The poets are working with long-existing Māori and Christian religious concepts, as well as established literary traditions. These concepts and traditions are not de novo; they are built on mythological understandings which are pre-colonial, brought from Europe, and developed in New Zealand through "close encounters." 387 The garden poetry is in conversation with early New Zealand garden poetry and is, I suggest, part of a New Zealand women's 'Bethellian' tradition. Whenua poetry ties into Māori mythological understandings of the land as maternal and feminine. The birth and death poems in the last section merge Christian and Māori religious understandings of land. These show the development of a poetic tradition in New Zealand women's poetry in which birth and death are experiences which allow for a spiritual and religious connection to the land.

This chapter evidences a landed religio-spiritual poetics. This poetics in part confirms the expressions of a "shared love of the land" set out in the beginning of this chapter. It also shows that for New Zealand women poets this spiritual connection to the land is complicated. The poetry does not clearly align with one tradition, but instead there is a complex imbrication of cultures, mythologies, vocabularies and imageries. Code-switching, different literary traditions and narrative

\footnotetext{
${ }^{386}$ I want to note the absence, in this chapter, of the work of Ruth Dallas, whose poetry repeatedly takes the land as its subject matter, using spiritual articulation to do so (see "South and North of the City" from Shadow Show (Christchurch: Caxton Press, 1968)). The spiritual qualities of Dallas' poetry deserve further study, which regrettably could not be achieved within the parameters of this thesis.

387 van der Veer, Imperial Encounters, 3.
} 
techniques present a poetry of land which revels in entanglement. The gender dimensions of the poetry examples distinguish this landed poetry as distinctly feminine. While exhibiting a varied and diverse range of whenua/land poems, collectively these poets present a tradition of New Zealand feminine poetics by choosing which understandings of land to focus on and which to discard. The poetry therefore models the negotiations between different mythological and theological frames of reference. ${ }^{388}$ It also demonstrates how the New Zealand woman poet exercises control over representations of land by specifically utilising traditions, imageries and motifs aligned with feminised and maternal identities, experiences and understandings.

388 James, "Pitched at the Farthest Edge", 131-133. 


\section{CONCLUSION}

Remarkably, the analysis of literature is not a prominent part of the contemporary study of New Zealand religion. This is regrettable. As I have demonstrated, New Zealand women's poetry is a rich and rewarding site for the study of religion. This thesis has sought to explore the articulation of religion in the poetry of New Zealand women since the 1970s. Focusing on three different themes, I analysed a wide selection of poems assessing the place of religion within it. My thesis has revealed religion to be a dynamic and important element in New Zealand women's poetry.

In this study I focused on religion and poetry, rather than 'religious poetry', and addressed a diverse set of poems written by a range of women writers. These poems show pervasive and expansive use of religious and spiritual language and representations. Eschewing a rigid secularreligious binary, I adopted a trialectical framework for my analysis which allowed the identification of religion beyond narrowly conceived boundaries, whilst also acknowledging dynamic interaction between religion, spirituality and secularity. Granting weight to both religious and literary studies, I drew upon scholarly contributions from both fields. It is not enough to simply state that there is religion in New Zealand women's poetry; religion is remarkably present, pervasive, consequential and continuing, and therefore I have brought it into vital conversation with theorists to understand how its presence matters. My study has sought to develop new analytical frameworks by bringing literary theorists and religion scholars into conversation with each other. The variegated observations afforded by each of my chosen themes shows how religion is expressed in New Zealand women's poetry in a myriad of ways.

In my first chapter, I showed that the domestic theme in New Zealand women's poetry provides potent examples of spiritual and religious expression, particularly when this theme is opened up and understood as more than simply a paradigm of feminine happiness or incarceration. New Zealand literature's discordant reception of women's poetry has meant that domesticity has often been stigmatised, rejected or over-looked. Building on the scholarship of Emily Abel and 
Callum Brown, I suggested links between declining church attendance and the de-valorisation of the domestic in New Zealand. Using Ivan Illich's concept of "shadow work", I argued for a broadening of the domestic category to illuminate rich religious and spiritual poetic readings. Poems by Airini Beautrais and Cilla McQueen show quotidian representations of kitchen transcendence and an alternative to the literary trope of the Angel in the House. In the poetry of Jenny Bornholdt and Martha Morseth, the anecdotal poem, a common form in New Zealand poetry, proves to be a mode in which religious imagery and spiritual articulation can be folded into descriptions of the everyday with relative ease. In poems from Meg Campbell and Tusiata Avia the domestic sphere is expanded to include poetry which is bleak and threatening. In these poems, imagery of spiritual transcendence is used to texture and translate the dark dimensions of the domestic sphere and experience. My analysis of religious and spiritual elements in these poems demonstrated the importance of attending to the domestic New Zealand literature, because the category is a profound vehicle for spiritual and religious reflection.

The gender theory which emerged with second-wave feminism focused closely on female bodily autonomy, agency and reclamation, and this is widely represented in poetry. In the second chapter, applying Mayra Rivera's theory of somatic and carnal poetics, I examined the interweaving of body-words with religious language. My analysis identified a tendency in some somatic poetry to portray the female body in a spiritual but abstracted manner. This is evident, for example, in poems by Jenny Powell-Chalmers, Jenny Bornholdt and Rachel McAlpine, in which the body is metaphorically fragmented, spiritualised and subsumed into an imagery of plants and herbs. Carnal poetics utilises obviously religious language and emphasises flesh over body, and is represented in poems by Tayi Tibble, Rachel McAlpine, Heather McPherson and Hadassah Grace. My analysis showed the poets' embrace of the flesh and movement towards an enfleshed thealogy, in which the feminine is deified. Both the somatic and the carnal poetics indicate different styles in which New Zealand women poets represent the body with religious and spiritual imagery. 
The third chapter analysed the theme of whenua/land, one of the more ubiquitous, welltrodden themes in New Zealand literature. Attention to religious and spiritual elements revealed a landed religio-spiritual poetics, one in which biculturalism and gender play a vital role. The poets I examined negotiate between different mythological and theological frames of reference when writing about land. Poems by Hannah Mettner, Sue Wootton and Jenny Bornholdt work within a tradition of garden poetry, in the footsteps of Ursula Bethell. This Bethellian tradition noticeably diverts from early New Zealand colonial garden verse and its project of amelioration by bringing the garden into conversation with religion in acutely personal and individual ways. Roma Potiki, Keri Hulme and Bernadette Hall present another tradition, one in which land is depicted as feminine and maternal. This tradition has notable bicultural leanings using both Māori and Christian mythology to describe land. After establishing these two traditions of land poetry, I focused on poems which used birth and death rituals and concepts of the afterlife to connect to land, using examples from Anne Kennedy, Bernadette Hall, Anahera Gildea and Tayi Tibble. These poems evidence a bicultural poetry, built on both the Bethellian and whenua traditions, which engages with the religious and spiritual motifs which arise in response to existential events in the poetry. Such poems are illustrative of how women's experience has forged a shared bicultural gendered space. This is not a simple shared space, however, and the poems discussed in this last chapter complicate and highlight postcolonial differences of privilege and power.

While not exhaustive, these themes have been valuable in illustrating how religion permeates New Zealand women's poetry in varied and often unexpected ways. The analysis of the poetry has also revealed some significant overlapping themes. There are shared contours which show strains of similarity in the articulations of religion and spirituality. There is a gravitation back to corporeality, nature imagery and liminality. The themes allow for a kaleidoscopic switching to take place, and to illuminate shared features in different ways. They show that, from the 1970s until now, at the high point of New Zealand secularity, the poetry of women has been imbued with religion. This appears to have occurred in the poetry despite the remarkable inattention given to this 
in scholarship. Popular proclamations of secularity have not aided or advanced study, but rather have stifled it. To find religion present in the poetry, and not just present but picked up, interrogated, celebrated and questioned, suggests that studies of New Zealand culture over the last fifty years which have claimed revisionism, have not been revisionist enough. The New Zealand cultural secular remains bathed in religion, and this can be studied with acuity in its poetry.

All the poems I have studied in this thesis show religion to be a highly relevant category for New Zealand literature and for the study of New Zealand's culture. Despite the purported "awkward" and "unfashionable" place of religion in New Zealand literary scholarship, I have not found its usage in the poetry at all uncomfortable or anachronistic. In fact, I have shown that the poetic genre easily and subtly offers a space for us to study 'religion and literature' in New Zealand. Blanket secular arguments disable an engagement with what is occurring in the poetry and with the words poets choose to use, their resonances and creative and constructive theologies.

This has also been a project about women, women's literature and women's articulations of religion. The study has demonstrated that questions of religion in New Zealand literature are not independent of gender. A question going forward in this area of study is whether a similar project focused on male poets would render similar findings? In the women's poetry I have studied there is a relatively easy use of religious metaphor. A gender-attuned analysis, which tacks against dominant trends within studies of religion and literature, unveils how religion is linked into gendered spaces, concepts and themes in women's poetry. A future study should explore the reasons for this gender-religious dynamic, and interrogate, to a greater extent, whether an andro-secularity has dominated New Zealand literary scholarship to the exclusion of women and religion.

The lack of New Zealand literary scholarship on religion may be explained through the fasthold of cultural nationalism, or by the dominance of the secular narrative. However, the fact that religious studies in New Zealand has not attended more to literature is also surprising. The "loud silence" of religion in New Zealand's historical writing has been identified, but similar attention has 
not been given to literary scholarship. If it had been, studies would have found that the theory of "silence" does not translate to New Zealand women's poetry; religion is far from absent, if anything it is loquacious. This provides us with the capacity to view the entire field of New Zealand literature in a different light.

An analysis of religion in the New Zealand novel, or the short story, would interrogate whether the wealth of religious and spiritual articulation found in poetry is consonant with other literary forms. Similarly, this thesis was periodised, with the selection bound to poetry published from 1970 to 2019. Unbinding this periodisation and applying a similar reading to New Zealand women's literature at a different period would broaden an understanding of religion and literature in New Zealand. One obvious pathway to explore would be an analysis of religion in the poetry of the literary nationalists. This has not been done sufficiently, as the acceptance of the secularism of the literary nationalists has dominated and flattened most scholarship on the subject. As long as we are prepared to discuss religion in more expansive ways and reject predilections of a teleological and linear sociological secularisation, the poetry of the literary nationalists could provide a better understanding of how religion was handled poetically during the cultural nationalist period. The rejection of religion by the literary nationalists is not necessarily synonymous with its nonexistence. Additionally, it is worth considering whether more restraints on women writers at this time, coupled with greater religious participation by women, may have produced different articulations of religion from their male peers.

This thesis has shown the value of paying attention to conversations and voices that are peripheral. Assumptions of a pervasive secular canopy and of a male-centred authorial voice can be considered as conceptually central. These are centres I have acknowledged but moved away from. Peripheries are relative, but in New Zealand both religion and women's voices have arguably spent much time on the margins of academic and cultural discourse. The productivity and illumination 
gained by moving away from centres makes a descriptive argument for greater focus on the productive, innovative and often surprising peripheries. 


\section{BIBLIOGRAPHY}

\section{Poetry}

Alexander, W. F., and A. E. Currie, eds. A Treasury of New Zealand Verse. Auckland: Whitcombe and Tombs Limited, 1926.

Adcock, Fleur. Poems1960-2000. Newcastle upon Tyne: Bloodaxe, 2000.

Andrews, Angela. Echolocation. Wellington: Victoria University Press, 2007.

Avia, Tusiata. Fale Aitu: Spirit House. Wellington: Victoria University Press, 2016.

Baker, Hinemoana. mātuhi | needle. Wellington: Victoria University Press, 2004.

Baysting, Arthur, ed. The Young New Zealand Poets. Auckland: Heinemann Educational Books, 1973.

Beautrais, Airini. Secret Heart. Wellington: Victoria University Press, 2006.

Bethell, Ursula. From a Garden in the Antipodes. London England: Sidgwick \& Jackson, 1929.

—. Vibrant with Words: The Letters of Ursula Bethell. ed. Peter Whiteford. Wellington: Victoria University Press, 2005.

—. Ursula Bethell: Collected Poems. ed. Vincent O’Sullivan. Wellington: Victoria University Press, 2014.

Bornholdt, Jenny. This Big Face. Wellington: Victoria University Press, 1988.

—-. These Days. Wellington: Victoria University Press, 2000.

—-. The Rocky Shore. Wellington: Victoria University Press, 2008.

Bornholdt, Jenny, Gregory O'Brien and Mark Williams, eds. An Anthology of New Zealand Poetry in English. Auckland: Oxford University Press, 1997. 
Brown, James. “Introduction.” In The Nature of Things: Poems from the New Zealand Landscape ed. James Brown, photography by Craig Potton, 8-13. Nelson: Craig Potton Publishing, 2005.

Brown, Amy. The Odour of Sanctity. Wellington: Victoria University Press, 2013.

Camp, Kate. Beauty Sleep. Wellington: Victoria University Press, 2005.

--. The Mirror of Simple Annihilated Souls. Wellington: Victoria University Press, 2010.

Campbell, Meg. The Way Back: poems. Pukerua Bay: Te Kotare Press, 1981.

Charman, Janet. Snowing Down South. Auckland: Auckland University Press, 2002.

Congreve, William. The Mourning Bride. London: Jacob Tonson, 1679.

Dallas, Ruth. Shadow Show. Christchurch: Caxton Press, 1968.

Edmond, Lauris and Bill Sewell. Essential New Zealand Poems. Auckland: Godwit Press, 2001.

Edmond, Lauris. In Middle Air: Poems. Christchurch: Pegasus Press, 1975.

—-. Late Song. Auckland: Auckland University Press, 2000.

Ensing, Riemke, ed. Private Gardens: An Anthology of New Zealand Women Poets. Dunedin: Caveman Publications, 1977.

Evans, Miriama, Harvey McQueen and Ian Wedde, eds. The Penguin Book of Contemporary New Zealand Poetry: Nga Kupu Titohu o Aotearoa. Auckland: Penguin, 1989.

Gildea, Anahera. Poroporoaki to the Lord My God: Weaving the Via Dolorosa: Ekphrasis in Response to Walk (Series C) by Colin McCahon. Wellington: Seraph Press, 2016.

Glover, Denis. The Arraignment of Paris. Christchurch: The Caxton Press, 1937.

Grace, Hadassah. How To Take Off Your Clothes at the Picnic. Auckland: Dead Bird Books, 2019. 
Green, Paula. Wild Honey: Reading New Zealand Women's Poetry. Auckland: Massey University Press, 2019.

Hall, Bernadette. The Merino Princess: Selected Poems. Wellington, Victoria University Press, 2004.

Harvey, Siobhan, James Norcliffe, and Harry Ricketts, eds. Essential New Zealand Poems: Facing the Empty Page. Auckland: Godwit, 2014.

Hawken, Dinah. It Has No Sound And Is Blue. Wellington: Victoria University Press, 1987.

--. Ocean and Stone. Wellington: Victoria University Press, 2015.

Hulme, Keri. Strands. Auckland: Auckland University Press, 1992.

Hyde, Robin. The Book of Nadath, introduction and notes by Michele Leggott. Auckland: Auckland University Press, 1999.

Johnston, Andrew and Robyn Marsack. "Introduction.” In Twenty Contemporary New Zealand Poets: An Anthology, ed. Andrew Johnston and Robyn Marsack, 11-17. Manchester: Carcanet Press, 2009.

Kennedy, Anne. Sing-song. Auckland: Auckland University Press, 2003.

Manhire, Bill. Milky Way Bar. Wellington: Victoria University Press, 1991.

--. How To Take Off Your Clothes at the Picnic: Poems. Wellington: Wai-te-ata Press, 1977.

--. 'Preface.' In Twenty Contemporary New Zealand Poets: An Anthology, Andrew Johnston and Robyn Marsack, 69-70. Manchester: Carcanet Press, 2009.

Marsh, Selina Tusitala. Dark Sparring. Auckland: Auckland University Press, 2013.

McAlpine, Rachel. Stay at the Dinner Party. Dunedin: Caveman Press, 1977.

—-. Selected Poems. Wellington: Mallinson Rendel Publishers Ltd., 1988. 
McPherson, Heather. A Figurehead: a face. Wellington: Spiral, 1982.

McQueen, Cilla. Benzina. Dunedin: John McIndoe Limited, 1988.

-. Fire-Penny. Dunedin: University of Otago Press, 2005.

Menzies, Rosemary. I Asked The Moon: Poems. Auckland: Rosemary Menzies, 1981.

Mettner, Hannah. Fully Clothed and So Forgetful. Wellington: Victoria University Press, 2017.

Morris, Paul, Harry Ricketts and Mike Grimshaw, eds. Spirit in a Strange Land: A Selection of New Zealand Spiritual Verse. Auckland: Godwit, 2002.

-. Spirit Abroad: A Second Selection of New Zealand Spiritual Verse. Auckland: Godwit, 2004.

O’Sullivan, Vincent. An Anthology of 20th century New Zealand Poetry. London: Oxford University Press, 1970.

--. Wellington: Oxford University Press, 1976.

--. Auckland: Oxford University Press, 1987.

Patmore, Coventry. The Angel in the House, together with, The Victories of Love. London: Routledge, 1905.

Powell, Anne. Tree of a Thousand Voices. Wellington: Steele Roberts, 2010.

Powell-Chalmers, Jenny and Anna Jackson. Locating the Madonna. Wellington: Seraph Press, 2004.

Potiki, Roma. Stones in Her Mouth. Auckland: IWA Associates, 1992.

—-. Shaking the Tree. Wellington: Steele Roberts Ltd., 1998.

-.. Oriori. Auckland: Tandem Press, 1999.

Smither, Elizabeth. Professor Musgrove's Canary. Auckland: Auckland University Press, 1986. 
Summers, Llew and Bernadette Hall. The Way of the Cross. Christchurch: The Cathedral of the Blessed Sacrament, 2006.

Tibble, Tayi. Poūkahangatus. Wellington: Victoria University Press, 2018.

Wevers, Lydia, ed. Yellow Pencils: Contemporary Poetry by New Zealand Women. Oxford: Oxford University Press, 1988.

Wootton, Sue. Magnetic South. Wellington: Steele Roberts, 2008.

Wright, Ursula Joan. Over a Long Life. Christchurch: U.J. Wright, 1988.

Yelich, Sonja. Clung. Auckland: Auckland University Press, 2004.

\section{Other Scholarship}

Abel, Emily K. Hearts of Wisdom: American Women Caring for Kin, 1850-1940. Cambridge, Mass.: Harvard University Press, 2000.

Allen, Douglas. "Mircea Eliade's Phenomenological Analysis of Religious Experience.” Journal of Religion 52 (2) (1972): 170-186.

Anderson, Atholl, Judith Binney and Aroha Harris. Tangata Whenua: A History. Wellington: Bridget Williams Books, 2015.

Anderson, Elizabeth, Andrew Radford, and Heather Walton., eds. Modernist Women Writers and Spirituality A Piercing Darkness 1st Edition. London: Palgrave Macmillan UK, 2016.

Anderson, Hephzibah. “Christmas Carol.” The Guardian.

https://www.theguardian.com/books/2005/dec/04/poetry.features (Accessed August 21 2019).

Arthur, Jake. Green Thoughts: The Forms, Affordances, and Politics of Garden Poetry. Thesis: Victoria University of Wellington, 2016. 
--. "Fond human enclosures': Gardening and belonging in Bethell's From a Garden in the Antipodes." Journal of New Zealand Literature, 35 (1) (2017): 28-49.

Attridge, Derek. “'This Strange Institution Called Literature': An Interview with Jacques Derrida.” in Jacques Derrida, Acts of Literature, ed. Derek Attridge, 33-75. London: Routledge, 1992.

Auckland Women's Liberation New Zealand. Broadsheet.

--. July 1973, No.11.

--. September 1974, No. 22.

--. "Women and Religion." December 1975, No. 25.

—-. "Special Issues: Writings from the Women's Movement." August 1975.

—-. "Motherhood: Hating it and Loving it." December 1985, No. 135.

--. "Body and Soul.” Winter 1995, No. 206.

Barrowman, Rachel. "History and Romance: The Making of the Centennial Historical Surveys.” In Creating a National Spirit: Celebrating New Zealand's Centennial ed. William Renwick, 161-177. Wellington: Victoria University Press, 2004.

Battersby, Christine. Gender and Genius: Towards a Feminist Aesthetics. Indiana: Indiana University Press, 1989.

Bender, Courtney and Anne Taves. "Introduction: Things of Value.” What Matters? Ethnographies of Value in a Not So Secular Age, eds. Courtney Bender and Anne Taves, 1-33. New York: Columbia University Press, 2012.

Besecke, Kelly. "Seeing Invisible Religion: Religion as a Societal Conversation about Transcendent Meaning." Sociological Theory, 23 (2) (2005): 179-196. 
Betcher, Sharon V. "Becoming Flesh of My Flesh: Feminist and Disability Theologies on the Edge of Posthumanist Discourse.” Journal of Feminist Studies in Religion, 26 (2) (2010): 107118.

Bluck, John. Long, White and Cloudy: In Search of a Kiwi Spirituality. Christchurch: Hazard Press, 1998.

Blundell, Sally. "Paula Green's Epic Collection of 150 years of NZ Women's Poetry.” The New Zealand Listener August 30 (2019). https://www.noted.co.nz (Accessed September 5, 2019).

Braidotti, Rosi. Nomadic Subjects: Embodiment and Sexual Difference in Contemporary Feminist Theory 2nd ed. New York: Columbia University Press, 2011.

Brookes, Barbara. “A Germaine Moment: Style, Language and Audience.” In Disputed Histories: Imagining New Zealand's Pasts, eds. Tony Ballantyne and Brian Moloughney, 191-203. Dunedin: Otago University Press, 2006.

-.. A History of New Zealand Women. Wellington: Bridget Williams Books, 2016.

-. "Contextualising Caring in New Zealand." In Past Caring? Women, Work and Emotion, eds. Barbara Brookes, Jane McCabe and Angela Wanhalla, 17-36. Dunedin: Otago University Press, 2019.

Brookes, Barbara, Jane McCabe and Angela Wanhalla. "Introduction.” In Past Caring? Women, Work and Emotion, eds. Barbara Brookes, Jane McCabe and Angela Wanhalla, 9-15. Dunedin: Otago University Press, 2019.

Brown, Callum. The Death of Christian Britain: Understanding Secularisation 1800-2000. 2nd ed. London: Routledge, 2009.

Burke, Kenneth. The Rhetoric of Religion: Studies in Logology. Berkeley: University of California Press, 1970. 
Burrus, Virginia. "Seducing Theology.” Theology \& Sexuality, 18 (2) (2012): 118-121.

Butler, Judith. "Sex and Gender in Simone De Beauvoir's Second Sex." Yale French Studies, 72 (1986): 35-49.

-. Bodies That Matter: On the Discursive Limits of Sex. New York: Routledge, 1993.

Cadogan, Tui. “A Three-Way Relationship, God, Land Place: A Maori Woman Reflects.” In Land and Place: Spiritualities from Aotearoa: He Whenua, He Wāhi, eds. Helen Bergin and Susan Smith, 27-44. Auckland: Accent, 2004.

Cixous, Hélène. "The Laugh of the Medusa." Translated by Keith Cohen and Paula Cohen. Signs (Summer 1976): 875-893.

Christ, Carol P. “The Last Dualism: Life and Death in Goddess Feminist Thealogy.” Journal of Feminist Studies in Religion, 27 (1) (2011): 129-145.

Clifton, Jane. "Choice, Bro.” The New Zealand Listener, July (2010): 14-18.

Courtney, Caroline. "Religion: Who Needs It?” North \& South, 253 (April) (2007): 66-77. http://web.ebscohost.com/ (Accessed September 7, 2019).

Cox, Shelagh, ed. Public and Private Worlds: Women in Contemporary New Zealand. Wellington: Allen and Unwin, 1987.

De Beauvoir, Simone. The Second Sex. Translated by Howard Madison Parshley. London: J. Cape, 1953.

Dennison, John. Seamus Heaney and the Adequacy of Poetry. New York: Oxford University Press, 2015.

--. "The seam of light: The Bible, the Gospel Hall, the Poet." Journal of New Zealand Literature, 36 (2) (2018): 161-169. 
Evans, Patrick. "Spectacular Babies: The Globalisation of New Zealand Fiction.” World Literature Written in English, 38 (2) (2000): 94-109.

Eyre, Lisa. Spirituality, Identity and Landscape in Pakeha Literary Fiction, 1975-2009. Thesis: Victoria University of Wellington, 2012.

Fairburn, A. R. D. The Woman Problem \& Other Prose. Auckland: Blackwood and Janet Paul Ltd., 1967.

Fraiman, Susan. Extreme Domesticity: A View from the Margins. New York: Columbia University Press, 2017.

Foucault, Michel and Jay Miskowiec. “Of Other spaces.” Diacritics, 16 (1) (1986): 22-27.

Garner, Theresa. "Germaine Greer Back at Scene of Dubious Crime.” New Zealand Herald (2003).

Gildea, Anahera. "Kōiwi Pāmamao - The Distance in our Bones." The Pantograph Punch. https://pantograph-punch.com/posts/bones (Accessed January 13 2020).

Glissant, Édouard. Poetics of Relation. Translated by Betsy Wing. Ann Arbor: University of Michigan Press, 1997.

Green, Paula and Harry Ricketts. 99 Ways into New Zealand Poetry. Auckland: Vintage, 2010.

Greer, Germaine. The Female Eunuch. London: Paladin, 1971.

--. "The Tulsa Center for the Study of Women's Literature: What We Are Doing and Why We Are Doing It.” Tulsa Studies in Women's Literature, 1 (1) (Spring, 1982): 5-26.

Groover, Kristina K., ed. Things of the Spirit: Women Writers Constructing Spirituality. Indiana: University of Notre Dame Press, 2004.

Goldenberg, Naomi R. Changing of the Gods: Feminism and the End of Traditional Religions. Boston: Beacon Press, 1979. 
--. Resurrecting the Body: Feminism, Religion and Psychoanalysis. New York: Crossroad, 1993.

Guy, Laurie. Shaping Godzone: Public Issues and Church Voices in New Zealand 1840-2000.

Wellington: Victoria University Press, 2011.

Harraway, Donna. Simians, Cyborgs and Women: The Reinvention of Nature. London: Free Association Books, 1991.

Harris, Sam. End of Faith: Religion, Terror, and the Future of Reason. New York: W.W. Norton \& Co. 2004.

Hart, Kevin. "Religion and Literature?.” Religion and Literature, 41 (2) (2009): 143-147.

--. Poetry and Revelation: For a Phenomenology of Religious Poetry. London: Bloomsbury Academic, 2018.

Heath, Eric. [cartoon]. The Dominion, 9 March 1972.

Helmreich, Anne. The English Garden and National Identity: The Competing Styles of Garden Design, 1870-1914. Cambridge: Cambridge University Press, 2002.

Hulme, Keri. "Mauri: An Introduction to Bicultural Poetry in New Zealand." In Only Connect: Literary Perspectives East and West, eds. G. Amirthanayagam, and S. C. Harrax, 290-310. Adelaide: Centre for Research in the New Literatures in English, 1981.

Hunt, Sam. "Pieces of Nine.” The New Zealand Listener, April 17 (1976): 32-33.

Illich, Ivan. "Shadow Work.” Philosophica 26 (2) (1980): 7-46.

Irigaray, Luce. "When Our Lips Speak Together.” Signs, 6 (1) Women: Sex and Sexuality, Part 2 (1980): 69-79.

-. Luce Irigaray: Key Writings. New York: Continuum, 2004. 
James, Trevor. "'Pitched at the Farthest Edge': Religious Presence and the Landscape in Contemporary New Zealand Poetry.” In Mapping the Sacred: Religion, Geography and Postcolonial Literatures, eds. Jamie S. Scott and Paul Simpson-Housley, 131-154. Amsterdam: Rodopi, 2001.

Jong, Erica. Fear of Flying. London: Secker \& Warburg, 1974.

Kanongata'a, Keiti Ann. "Domestic Theology." The Pacific Journal of Theology, 2 (15) (1996): $73-75$.

Kearns, Cleo Mcnelly. "Religion, Literature, and Society in the work of T. S. Eliot.” The Cambridge Companion to T.S. Eliot, ed. Anthony David Moody, 77-93. Cambridge: Cambridge University Press 1994.

Kennedy, Melissa. Striding Both Worlds: Witi Ihimaera and New Zealand's Literary Traditions. New York: Rodopi, 2011.

--. “The Māori Renaissance from 1972.” In New Zealand literature in A History of New Zealand Literature, ed. Mark Williams, 277-290. Cambridge: Cambridge University Press, 2016.

Keown, Michelle. Postcolonial Pacific Writing: Representations of the Body. London: Routledge, 2005.

King, Michael. Whina: A Biography of Whina Cooper. Auckland: Hodder and Stoughton, 1983.

Lambert, Kelly. Calling the Taniwha: Mana Wahine Māori and the Poetry of Roma Potiki. Thesis: Victoria University of Wellington, 2006.

Lineham, Peter. "The Controversy Over the Recognition of Religious Factors in New Zealand History." The Spirit of the Past: Essays on Christianity in New Zealand History, eds., Geoffrey Troughton and Hugh Morrison, 25-42. Wellington: Victoria University Press, 2011. 
Luckmann, Thomas. The Invisible Religion: The Problem of Religion in Modern Society. New York: The Macmillan Company, 1967.

--. “Shrinking Transcendence, Expanding Religion?” Sociological Analysis 51 (2) (1990): $127-$ 138.

Mellon Working Group on Religion and Literature. "Literature and Religion for the Humanities: Seven Theses." Religion \& Literature, 46 (2014): 151-155.

Michie, Helena. The Flesh Made Word: Female Figures and Women's Bodies. Oxford: Oxford University Press, 1989.

Moffat, Kirstine. "Destruction, Transformation, Rebellion, Alienation: the Critique of Puritanism in pre-1930 New Zealand Novels.” JNZL, 16 (11) (1998): 86-96

--. "The Puritan Paradox: An Annotated Bibliography of Puritan and Anti-Puritan New Zealand Fiction, 1860-1940 — Part 1: The Puritan Legacy." Kōtare: New Zealand Notes \& Queries, 3 (1) (2000): 28-69.

-. “"The Manliest and Noblest of All Pursuits and Professions': Two Preacher Novelists.” In Sacred Histories in Secular New Zealand, eds. Geoffrey Troughton and Stuart Lange, 123138. Wellington: Victoria University Press, 2016.

Morris, Paul, Harry Ricketts and Mike Grimshaw. "Introduction.” Spirit in a Strange Land, eds. Paul Morris, Harry Ricketts and Mike Grimshaw, 9-14. Auckland: Godwit, 2002.

Morris, Paul. "Spirituality Abroad: Reflections on New Zealand Spirituality and Identity." In Spirit Abroad: A Second Selection of New Zealand Spiritual Verse, eds. Paul Morris, Harry Ricketts, and Mike Grimshaw, 217-29. Auckland: Godwit, 2004. 
_. "Who Are We? New Zealand Identity and Spirituality.” In New Zealand Identities:

Departures and Destinations, eds. James Liu, Tim McCreanor, Tracey McIntosh, and Teresia Teaiwa, 242-54. Wellington: Victoria University Press, 2005.

Nakao, Masami. “"The Gate to Another Garden': Text and Image in Jenny Bornholdt's These Days." In Writing at the Edge of the Universe, ed. Mark Williams, 151-164. Christchurch: Canterbury University Press, 2004.

Newton, John. Hard Frost: Structures of Feeling in New Zealand Literature, 1908-1945.

Wellington: Victoria University Press, 2017.

New Zealand History. "Spiral.” https://nzhistory.govt.nz/women-together/spiral (accessed May 25, 2019).

New Zealand Book Council. "McAlpine, Rachel.” http://www.bookcouncil.org.nz/writer/mcalpinerachel/ (Accessed August 17, 2019).

Økland, Jorunn. "Feminist Readings of the Bible." In The New Cambridge History of the Bible, 261-272. Cambridge: Cambridge University Press, 2015.

O’Leary, Michael. Social and Literary Constraints on Women Writers in New Zealand 1945-1970. Thesis: Victoria University of Wellington, 2011.

Orbell, Margaret. The Illustrated Encyclopaedia of Maori Myth and Legend. Christchurch: Canterbury University Press, 1995.

Parsons, Susan Frank., ed. The Cambridge Companion to Feminist Theology. Cambridge: Cambridge University Press, 2002.

Perris, Simon. "What does Hine-nui-te-pō Look Like? A Case Study of Oral Tradition, Myth and Literature in Aotearoa New Zealand.” Journal of the Polynesian Society 127 (4) (2018): 365-388. 
Porter, Roy. Flesh in the Age of Reason: The Modern Foundations of Body and Soul. New York: W. W. Norton \& Company, Inc., 2003.

Punday, D. Narrative Bodies: Toward a Corporeal Narratology. New York: Springer, 2003.

Raine, Katherine. "Domesticating the Land: Colonial Women's Gardening." In Fragments: New Zealand Social \& Cultural History, ed. Bronwyn Dalley and Bronwyn Labrum, 76-96. Auckland: Auckland University Press, 2000.

Reeder, Harry P. The Theory and practice of Husserl's Phenomenology, 2nd ed. Bucharest: Zeta Book, 2010.

Ricketts, Harry and Mark Williams. "From Hiruharama to Haitaitai." In A History of New Zealand Literature, ed. Mark Williams, 227-245. Cambridge: Cambridge University Press, 2016.

Ricketts, Harry. “Allen Curnow: A Post-Christian Poet.” Journal of New Zealand Literature, 36 (2) (2018): 147-159.

Rich, Adrienne. Blood, Bread and Poetry: Selected Prose 1979-1985. London: Virago, 1987.

Rivera, Mayra. Poetics of the Flesh. London: Duke University Press, 2015.

Roberts, Hugh. "Is it a poem or a blog?.” The New Zealand Listener, 31 July (2010). https://www.noted.co.nz/archive/listener-nz-2010/is-it-a-poem-or-a-blog/ (accessed June 6, 2019).

--. "New Zealand Literature in the Program Era, or, the Spirit of Nationalism Past." In History of New Zealand Literature, ed. Mark Williams, 374-387. New York: Cambridge University Press, 2016.

Saint Matthew's Westminster "Ignatius Loyola." www.stmw.org/ignatius.html (accessed 17 August 2019). 
Scott, Nathan. Negative Capability: Studies in the New literature and the Religious Situation. New Haven: Yale University Press, 1969.

Shiva, Vandana. Staying Alive: Women, Ecology, and Development. London: Zed Books, 1988.

Showalter, Elaine. "Killing the Angel in the House: The Autonomy of Women Writers." The Antioch Review, vol. 32, no. 3 (1972): 339-353.

Smaill, Anna. “Anecdote in Post-1990 New Zealand Poetry.” In A History of New Zealand Literature, ed. Mark Williams, 311-329. New York: Cambridge University Press, 2016.

Smart, Ninian. The Science of Religion and the Sociology of Knowledge: Some Methodological Questions. Princeton: Princeton University Press, 1973.

Spongberg, Mary. 'If She’s So Great, How Come So Many Pigs Dig Her? Germaine Greer and the Malestream Press." Women's History Review, 2 (3) (1993): 407-419.

Stafford, Jane. "Review: The Book of Nadath." Kōtare, 2 (1999): 82-86.

Staley, Lynn. The Island Garden: England's Language of Nation from Gildas to Marvell. Notre Dame: University of Notre Dame, 2012.

Stenhouse, John. “God's Own Silence: Secular Nationalism, Christianity and the Writing of New Zealand History." New Zealand Journal of History, 38 (2004): 52-71.

—-. "The Controversy Over the Recognition of Religious Factors in New Zealand History: Some Reflections." In The Spirit of the Past: Essays on Christianity in New Zealand History, eds. Geoffrey Troughton and Hugh Morrison, 43-54. Wellington: Victoria University Press, 2011.

—-. “'Like Strychnine in Its Bones'? Puritanism, Literary Culture, and New Zealand History.” Journal of New Zealand Literature, 30, (2012): 150-176.

Studstill, Randall. "Phenomenology, and the Sacred." Religious Studies, 36 (2) (2000): 177-194. 
Tacey, David. The Spirituality Revolution: The Emergence of Contemporary Spirituality. New York: Brunner-Routledge, 2004.

Taylor, Charles. A Secular Age. Cambridge: Belknap Press of Harvard University Press, 2007.

Tillich, Paul. The Religious Situation. London: Thames and Hudson, 1956 (first published 1932).

Troughton, Geoffrey. New Zealand Jesus: Social and Religious Transformations of an Image, 1890-1940. Bern: Peter Lang, 2011.

--. "Anti-Churchianity, Discursive Christianity, and Religious Change in the Twentieth-Century." The Journal of New Zealand Studies; 17 (2014): 93-106.

van der Veer, Peter. Imperial Encounters: Religion and Modernity in India and Britain. Princeton: Princeton University Press, 2001.

Vendler, Helen. "Domestication, Domesticity and the Otherworld." World Literature Today 51 (1) (1977): 23-28.

Vidler, Anthony, Michel Foucault and Pamela Johnston. "Heterotopias.” AA Files 69 (2014): 18-22.

Walcott, Derek. "The Antilles, Fragments of Epic Memory: The 1992 Nobel Lecture.” World Literature Today, 67 (2) (1993): 261-267.

Wallace, Christine. Germaine Greer, Untamed Shrew. Boston: Faber and Faber, 1998.

Wendt, Albert. “Tatauing the Post-Colonial Body.” Span, $42-43$ (April-October 1996): 15-29.

Whiteford, Peter. "Shall the Garden be a Paradise? Ursula Bethell's Encounter with Eden." Literature and Theology, 29 (2) (2015): 138-152.

--. "Eileen Duggan, 1894-1972." Kotare 2008. Special Issue - Essays in New Zealand Literary Biography Series Three: 'The Early Poets', eds. Paul Millar, Jane Stafford and Mark Williams. https://viewer.waireto.victoria.ac.nz (Accessed May 9 2019). 
Williams, Mark. "Introduction.” The Source of the Song: New Zealand Writers on Catholicism, ed., Mark Williams, 7-22. Wellington: Victoria University Press, 1995.

--. "Leaving the Straight Path: Cultural Time Travel in the Seventies." The Journal of New Zealand Studies, 4 (2006): 81-89.

--. “'When You're Dead You Go on Television': Sex, Death and Household Objects in Some New Zealand Poetry." Sport 42 (2014): 149-173.

Williams, Mark and Christine Lorre-Johnston, eds. “Afterlives of the Bible.” Journal of New Zealand Literature, 36 (2) (2018).

Woolf, Virginia. A Room of One's Own. London: Hogarth Press, 1935.

--. The Death of the Moth and Other Essays. New York: Harcourt Brace Jovanovich, 1974 (first published 1941).

Ziolkowski, Eric. "Religion and Literature: History and Method.” Brill Research Perspectives in Religion and the Arts, 3 (1) (2019): 1-112. 